

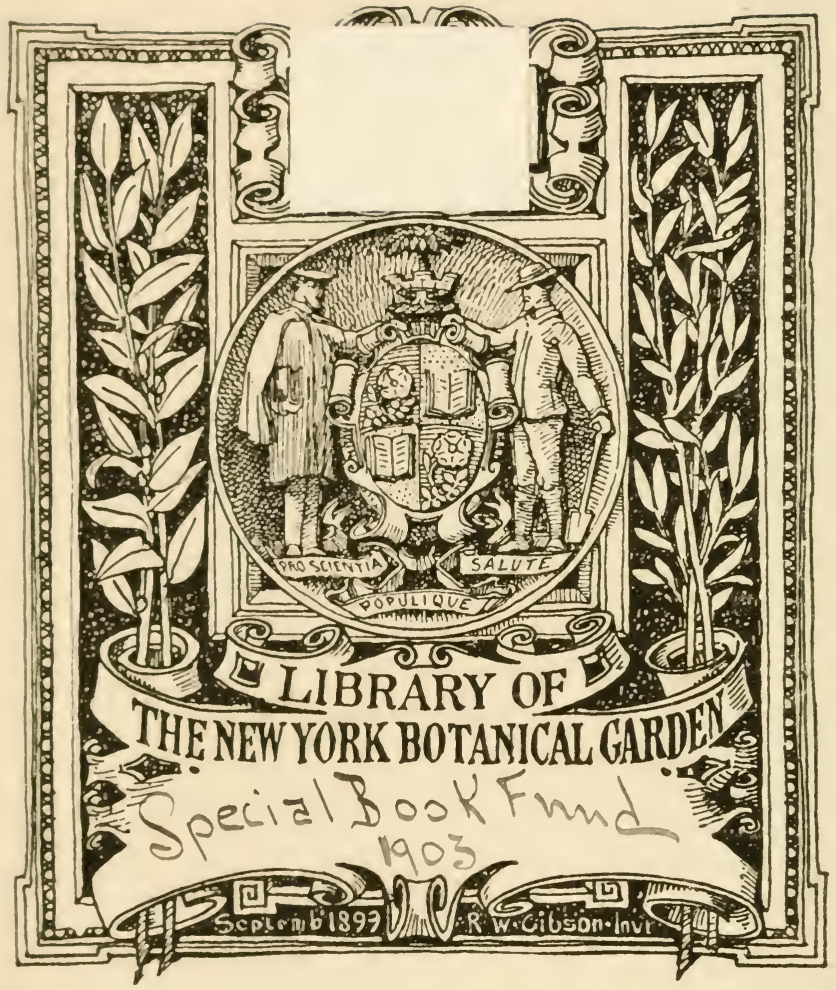









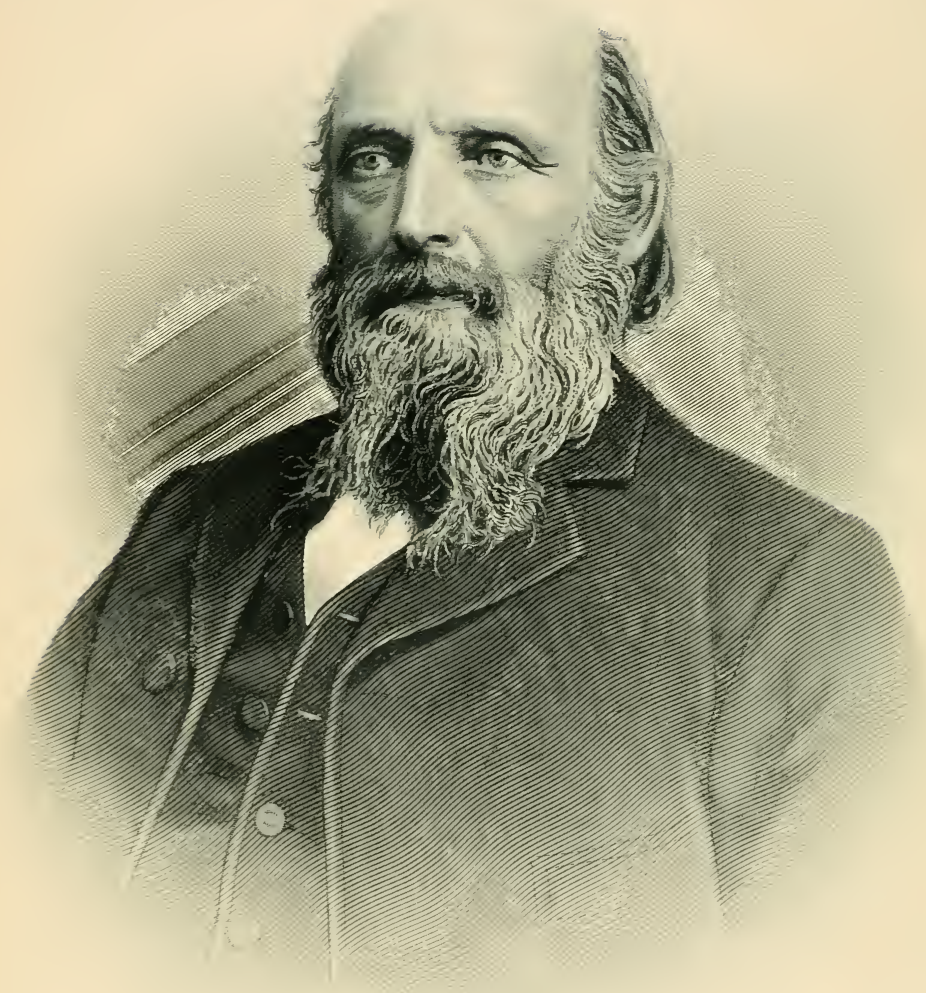

Theclirns Aterbat 


\section{FUNGAL FLORA}

OF THE

\section{LEHIGH VALLEY, PA.}

\section{DR. WILLIAM HERBST,}

Trexlertown, $\mathrm{Pa}$.

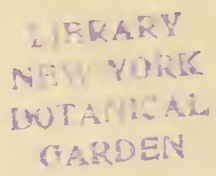

WITH ILLUSTRATIONS.

Allentown, PA.:

Berkemeyer, Keck \& Co., Printers.

I899. 
1.P4

$\mathrm{H}_{4} 3$

Dedicated to

C. G. Lloyd, of Cincinnati, Ohio. 


\section{L.IBRARY}

NEW YORK

BOTANICAL

\section{PREFACE.}

GARDEN

Since the year I834, in which occurred the death of Rev. Lewis David de Schweinitz, sixty-five years ago, nothing has been done in the study of the fungal flora of this fruitful valley. De Schweinitz published several works, and did a large amount of work, naming many new species. In those days all scientific works were published in Latin, and very few took any interest in the study.

It was my intention at first merely to publish a list of my collections, growing in the Lehigh Valley, but thinking it would be of very little benefit to this branch of Botany, I concluded to write out some of the principal characters of the natural orders, etc., getting permission from my friend, Prof. Charles H. Peck, State Botanist of New York, to use his specific characters of new species, which he had the kindness to determine for me. Professor Peck, through his annual reports to the State Museum, and correspondence, was my best teacher for the last twenty years. C. G. Lloyd, of Cincinnati, had the kindness to visit me for a number of years, giving me a fresh stimulus to this fascinating study by his assistance in working out somé interesting species. The principal works consulted were: Rev. M. J. Berkeley's Outlines of British Fungology; M. C. Cooke's British Fungi; British Funci by Rev. John Stephenson; The Mycologic Flora of the Miami Valley and North American Fungi, by A. P. Morgan; Ebighaus and Dr. H. Lenz's Schwaemme des Deutschland in German. 
The most frequently consulted works were those of Prof. Chas. H. Peck; his Boleti of the United States is the best and only good reference to go by for our Boletus family.

'The spore measurements were from Professor Peck's works. The illustrations were all taken by myself from fresh specinens with a Hawkeye camera. I was not enough of an expert in photography to accomplish the ratio of comparative sizes which are given in the text.

No doubt this volume will be criticized by those who know more of this branch of Botany than I do; but it is consoling that it is not the only scientific work which has passed through the same ordeal.

I am ever so thankful to the contributors to whom I had referred above.

Trexlertown, August I, 1899 .

WM. HerbST, M.D.

\section{CORRIGENDA.}

The reader will please make the following corrections with a pencil on the pages and places indicated :

Page 17.-2. Acomycetes should read : 2. Ascomycetes.

Pa:e 19.-2. Uridinea should read: 2. Urelir:æ.

Page 52.-Agaricus serotinoides, Pk., should read P. serotinoides, Pk.

Page I23.-Under B. subtomentrsa, in the second line under Spores read "yellow cracked Boletus" instead of "red cracked Boletus." Page I75.- E. sanibuci should read E. sambuci.

Page 206.-Genus Phytophora should read Phytophthora.

Plate facing page 38: For Tricholoma terriferum read Tricholoma personata, and for Tricholoma personata read Tricholoma terriferum.

Plate facing page 56: For Entoloma rhodopolius read Entoloma clypeatus. 


\section{INTRODUCTION.}

FUNGI are crytogamic plants belonging, together with algæ and lichens, to the group of Thallophytes. Fungi, the plural, is pronounced with the $g$ soft, as funji. Fungus, the singular, with $g$ hard, as in gum.

Fungi are by far the most numerous of the group; it is easier to tell where they do not grow than where they do grow. To say that fungi are to be found everywhere would not be strictly true, but to say where they are not to be found would be puzzling. Not only are they to be found in shady woods, mossy dells, secluded lanes, fence corners, etc., but we meet with them in all situations where vegetable life is possible. They are both saprophytic and parasitic-saprophytic, growing on dead vegetable and animal matter; parasitic, growing on living vegetable and animal matter. We need not travel far from home to find specimens of our research. The unwelcome dry rot beneath our kitchen floors; the different species of mould infesting our preserved fruits; the yeast for raising our bread and brewing our beer; the mother of vinegar for our vinegar, are all due to fungi. From cesspool and sewers the minute dust-like spores rise into our dwellings unseen; they float into the air, producing disease and death. It is strongly proved that diphtheria, consumption, typhoid fever, are nothing more or less than the ravages of fungi spores.

Since fungi are so universal and play such an important part in the economy of nature, it behooves not only the botanist, but the physician, agriculturist or florist, to study them, get acquainted with their structure, life history, name, and their haunts, etc.

I know well that as a class those interesting objects of" 
creation are despised; they are even called by unappropriate names, such as "bad man's bread, woodwitch, devil's snuffbox, toadstool," etc. And those who take an interest in them are ridiculed as "non compos mentis," to spend time on such foolishness.

I have made fungi a special study for at least twenty years, and never was sorry for all the time spent. It afforded me many an hour of happiness during my leisure hours. Often when I would have a spell of "taedium vitæ," I would seek to the forests and green meadows for specimens, and before I knew I could exclaim : "This life is worth living after all," or exclaim with Prof. Henry Willey, in his "Instruction to the Study of Lichen "':

"If I could put my woods in song,

And tell what's there enjoyed,

All men would to my garden throng,

And leave the cities void.

In my lot no tulips blow ;

Snow-loving pines and oaks instead;

And rank the savage maple grow,

From Spring's first flush to Autumn red,

My garden is a forest ledge,

Which older forest bound."

It is a curious fact that ministers of the Gospel took such an interest in the study. I have three works on my bookshelf on fungi of which the authors are ministers of the Gospel: Rev. John Stephenson, of Glanus, England; Rev. M. J. Berkley, of England; Rev. Lewis Schweinitz, of Bethlehem.

It brings you in contact and correspondence with great and good men-who are similarly inclined. It brings you back to those good men who studied the subject years ago, as Muhlenberg, Linneus, Fries, and Schweinitz-all good and pious men.

It has often been alleged that the study of fungi has but few attractions, and cannot compete in interest with the study 
of algæ or lichens, together with the difficulty in preserving for future reference. It may be true of the delicate and elegant forms and beautiful tints of many seaweeds, as well as the graceful outlines of a fern. But every one is not privileged to dwell by the seashore; and as for ferns, the few different species of one locality are soon exhausted, and the collector soon gets tired, it becoming monotonous in not finding any more new material.

Fungi, on the contrary, as said before, abounds everywhere, and the collector can never declare the resources of his locality exhausted. Beautiful specimens are by no means rare, the pocket lens and microscope are sure of constant employment. The study of the different groups is indeed interesting and fascinating. There is nothing more wonderful than to investigate the manner and mode of reproduction through their sporesanalogous to seeds in the higher groups of plant life.

Spores are infinitely small seeds. The largest spore is microscopic-requiring at least a one-fifth objective or 360 diameter. They are developed from a preferred surface on the fungi, called the hymenium. They are so profuse that some mycologists attempted to estimate the number of spores, which might be produced by one single plant of Lycoperdon or puff ball, but the number so far exceeded to which the mind was accustomed to contemplate, that it was scarcely possible to realize their profusion. To prove the immensity of spore formation, take a common mushroom fully developed, cut the stem and place the gill surface on a sheet of paper and in a few hours there will be millions of spore dropped on the paper. Spores are of different shapes and color, do not vary in the species, always constant in size, form, and color-an important character for grouping some genera and species. It seems a universal law of nature, the more delicate the seeds and the more likely its destruction, there is provision made by the abundance of its production. Spores are either free on special 
cells called basidia or enclosed in elongated sacks or ascicorresponding to exogens and endogens in the phænogamia plants.

S'TRUCTURE. - There is no class of plants where there is so great a variety in structure as in the fungus class. It is true they are all cellular, but differ in biological structure from merely a mass of slimy myxogaster to a hard and ligneous polyporus.

There is so great a variety in structure of the different groups that it cannot be compressed within this introduction; even in the common mushroom family there is such a vast difference in structure as to make it a part of the differential character, such as the ephemeral Coprinus growing on manure heaps to the fairy ring Marasmius, which, when dry and shriveled, will revive again to its original structure. Beside the general tissue of which fungi are composed there exists in a genus of Agaric a class of distinct vessels which carry a milky fluid. They exist in all parts of the plant, especially in the softer parts; the genus is called Lactarius - the fluid is differently colored, mild or acrid. In many fungi something distinct from the cellular tissue seems to exist, in the form of a viscid or glutinous fluid which clothes the surface of the cap of agarics, more conspicuous during wet and damp weather. This secretion forms a good specific character, since it is always present in the same species. The structure of the different parts of a fungi is not always homogeneous; the cap of an agaric is generally more spongy than the stem, so are the gills or plates which may be waxy or watery in certain genus and heterogenous in structure with the rest of the plant. The gills of some species are deliquescent, forming a good generic character.

FORMs. - The forms which these singular plants assume are extremely diversified. In some instances they are shaped like an 
umbrella or parasol, in others the stem is absent; some are like a hedgehog, some are funnel shape.

Sometimes the form and color so nearly resemble that of an ox tongue (Fistulina hepatica) or the lobe of a liver. "Dr. Badhan says in the days of enchanted trees, you would not have cut it off to pickle or eat it on any account, lest the knight to whom it belonged should afterwards come to claim it of you."

In some species the form is that of coral (Clavaric), in some like a small stag horn, a spinning top or a base-ball; you will meet with every imaginable form. Indeed, so protean are they in shape, that description fails in giving an adequate idea of their variety.

Color.- In color they are almost as variable as in shape. We have all shades of red, from light pink to the deepest crimson; all the different shades of yellow, brown, from ochre to the deepest umber; and every gradation of black, from lead to sooty black, violet and purple, from solferina to the most beautiful amethyst. White or creamy tints are very common.

ODORs.-Odors are as varied as form and color-from the pleasant odor of a ripe apricot (chanterelle) to the most repugnant odor of a carrion. There are some which have the scent of new-mown hay, of violets, of anise, of new meal, etc., while some have the scent of garlic and tainted fish.

PROPERTIES. - Some persons are very fond of tasting, and with fungi they can have an opportunity to gratify that propensity; for in fungi they will meet with a variety of flavors, some of which will be calculated to please, and others to disgust. In the raw state, probably, the sharp and unpleasant taste prevails, but in the majority of species, which, when properly cooked, are made sweet and eatable. 
The number of poisonous species has, perhaps, been exaggerated; but of these there are many, and the dangerous properties of a few are extremely virulent. No golden rule can be established by means of which any one may detect at a glance the good from the bad, without that kind of knowledge which is applied to the discrimination of species. Yet, after all, the character of a half-dozen species or more of good esculent fungi can be acquired as easily as it is to distinguish between half a dozen birds, such as any schoolboy conld discriminate. There is no trouble with some species to identify; for instance, the morels no one can mistake, the puff balls are also so plain that it is utterly impossible to be mistaken. There is nothing more delicious than a morel or puff ball when used before decomposition has set in, as safe as an egg omelet.

Nearly all the accidental poisoning by toadstools occurs by neglecting to identify the Amanita family. There are at least four species of that family that contain large quantities of the alkaloid amanitine, which is very poisonous. And the external appearance is so much like some of the common edible mushrooms that it may very easily be mistaken.

One of the chief distinguishing characters of the Amanita family is the universal wrapper surrounding the plant when young, which, however, is ruptured when fully developed, leaving traces on the cap and stem in the form of discrete warts on the cap and a sheath around the base of the stem. The gills are also free from the stem, which are snow-white. The odor and taste is not in the least repugnant. The color of the cap varies so much that it is not a reliable character to go by. For further and more definite description of the character and diagnosis of the edible and poisonous, I would refer you to the subsequent list. It is said that boiling with condiments would modify the poisonous or toxic alkaloid.

Tanin or any astringent medicine is supposed to modify the 
poisonous effects of poisoned mushrooms. Some years ago I read an account of a professor on therapeutics in a southern medical college, examing a class in that branch. He put the question, viz: "In what manner does tanin act as an antidote to mushroom poisoning?"' After a few minutes deliberation one of the class pretended he knew, whereon the professor told him to give it. "He at once commenced by saying that he believed that tanic acid united with the mush of the mushroom and formed an insoluble tanate of mush, and there would be less room for the poison to act." The best antidote for counteracting the toxic effects of amanitine is undoubtedly atropia sulph. in heroic doses, pushed to dilitation of the pupils or the physiological effects. Doctor Shadle, of Shenandoah, as reported by Capt. Charles MacIlvaine, of Philadelphia, in the Medical and Surgical Reporter, December 12, I885, gives his treatment of a family treated with atropia.

The Italian use daturine, the alkaloid of the Datura stramonium, similar in properties to the atropia.

The chemistry of fungi is as yet very meagre; but there is little doubt that not only does the composition vary greatly in different species, as proved by their toxic or innocent properties, containing more or less of the poisonous alkaloid. They contain a relative proportion of proteid to the carbohydrates.

As they are the creatures of darkness and do not require sunlight, and instead of exhaling oxygen and appropriating carbon of carbon dioxide like the higher plants do, that chemical process is reversed, similar to that of the animal kingdom, that is, exhaling carbon dioxide. The most wonderful vitochemical action in fungi is displayed in the change of color of the flesh : there is hardly a tint of color that is not produced by breaking or bruising a fleshy fungi-golden yellow by different species of Lactarius, vivid blue by some of the Boleti, with some it is slow in changing or oxydizing, but in some it is 
almost instantaneous-in one case the Buletus minio-olivaceous, if you barely touch it, it turns to a vivid blue.

In some cases it assumes different colors. In the case of Lactarius deliciosus the juice is at first, when it exudes, red brick saffron, but soon, when exposed to the oxygen of the air, turns to greenish yellow. The black Russula, when cut or bruised, will soon turn to a brick red, a specific character.

Some species of Cortinarius turn to an azure blue on being bruised. This change of color to blue is so universally confined to dangerous species, that is given as a caution, that all species which exhibit a blue color, when cut or bruised, should on no account be eaten.

The chemical analysis of different species of fleshy fungi shows different proportions of the chemical or earthy element. Some also contain a large proportion of water, and very little solid matter. All of the Coprinus group have over 90 per cent. of water. The solid matter consists of phosphoric acid, malic acid, oxalic, magnesia and lime. The organic matter, besides water, are nitrogen in form of protein, starch, and sugar. Nitrogen always predominate, which gives them such nourishing properties, equal to beans or peas.

There is a peculiar attribute of the mycelium, in some of the fleshy fungi, to produce luminosity or phosphorescens. Many a superstitious way-faring man, being out late at night was frightened out of his wits, by taking this innocent vegetative phosphorescens for a fiery man or Satan himself. There are a number of species, which cause that luminosity: but more especially the mycelium of honey Agaric permeating an old decayed stump.

Luminosity in fungi has been observed in various parts of the world, and it was nearly always a species of Agaric which has produced the phenomenon. One of the best-known species is the Agaric olearius of the olive tree growing in the south of Europe. 
SPORES.-As said before, spores are the representatives of seeds in the higher plant-life. Through their medium the continuity of the species are kept up, each after its own kind, and as the tree is known by its fruit, so the spores are the principal medium to identify to what species they belong. They form a principal character of classification.

It is not such an easy matter to differentiate the different parts of a spore as it is a seed, on account of its minuteness. It must be done with the compound microscope, and under inconveniences, which you do not find necessary for a casual view of a seed. The outer covering of a spore is called the epispore, and is rough or smooth. They are of different shapes, oval, orbicular, angular, etc.

As for the germination of spores, nothing is very definite about that secret process. To form a mycelium from spores, there is not the least doubt it is not formed from a single spore, but from a mass of spores. There is a wonderful provision made for the dissemination of spores, equally as wonderful as the seeds of higher plants. The spiral threads of the Trichiæ are elastic and when ripe throw the spores to the four winds of heaven. You will find that provision in many instances in the fungi family. In case of the Sphærobolus Stellata, a nidularian fungi, which when touched or fully ripe the star-like limbs open or are inverted and expel the sporangia with such force to a considerable distance from its parents. I frequently observed its peculiarity while sitting on a decayed log where they grew. The puff-balls disseminate the spores by their rotundity. When ripe they loosen from the earth, are wafted over the rough surface of the earth, and by a small orifice or rupture of the covering, the spores are scattered to new territory. Insects are also great disseminators of spores, even as they are useful in cross-fertilizing of the higher plants, so even are they useful in keeping up the fungi world-" nothing. is created in vain." 
In the tribe of Phalloidæ the spores are immersed in a viscid fluid, which would prevent their diffusing in such a manner. This gelatinous substance has a peculiar attraction for insects, and in feeding on this slimy substance they imbibe spores and transfer them from place to place. The horse is even a beast to keep up the continuity of a certain edible mushroom, the Agaricus arvensis or horse mushroom. It is said that the spores will not germinate unless it passes through the entrails of the horse, which at the same time disseminate it. In England the droppings of the horses at the riding schools and circuses is highly prized for mushroom beds.

Spores are named according to their form and place in the systemic arrangement. Stylospores are really Basidiospores in the parasitic uridinæ, and only a stage of Ascosporous fungi. Conidiospores are also of the same nature, only they are free, that is, without a basidia or stalk. They are a stage of summer spores for the telentospores, to carry the plant over winter. They are also called the pseudospores, for they germinate and form first a prothallus, like unto ferns and hepatica.

Spermatia are minute elevated bodies on the leaves of green plants associated with the uridinæ, and are supposed to belong to the cycle of the life of Spheriaceæ fungi.

Sporangia are produced on the tips of branches of delicate threads; and when ripe they dehisce and shed the spores. They are restricted to moulds, mildew, etc.

Zoospores are oval spores contained in a sack, which, when ripe, opens and sheds the motile spores. Their movement is caused by small thread-like appendages. Oogonia or female fructification commences by a mycelium swelling. Antheridia, the counterpart of Oogonia, are the male part of the plant, and are fertilized by conjugation, when oospores are formed. Zygospores are limited to the Mucor family, and are fertilized by conjugation. 
There are a series of phenomena classed together under the name of polymorphism, dualism, dimorphism, which form a cycle of development of different kinds of spores. For instance, the Acidium berberidis, growing on the barberry bush, produces spores which will only germinate on the graminæ vegetation, producing the well-known wheat rust ('Trichobasis rubivera), and yet that does not complete the cycle: it requires a third kind of spores called puccinia spores, or brand spores, which in turn will only germinate on the barberry bush leaves.

It requires three different kinds of spores to complete a fully developed plant. I. Acidium ; 2. Uredo, and 3. Puccinia spores; the latter are called teleuto or winter spores, for they carry them through the winter in the form of brand.

You will meet with a number of instances of polymorphism, or dualism, in the fungi group. Dualism is of frequent occurrence in the Coniomycetes or Hypodermea of the Germans. It is quite certain that a large portion of the so-called species of Phoma, Cytispora, Septoria, Diplodia, are mere cases of dualism. All are interesting, so far as ascertained dualism is concerned; or as far as there may be a prospect of showing that they are the spermagonia of the ascophorous pyrenomycetous fungi.

There is no class of vegetation which shows so much wisdom in the display of organs for the purpose of the perpetuity of its kind as fungi do.

The minute dust-like spores, which are always in danger of being destroyed even by the morning dew, has provisions made almost as soon as born to form a fresh mycelium penetrating the stomata of a green leaf, there to perfect itself to form a nidus for a more permanent progeny. We mycologist can not help but exclaim with the Psalmist, "Marvelous and wonderful are Thy works, O Lord of hosts: in wisdom hast Thou made them all." 
PRESERVATION. - The preservation of fungi for future reference is a great obstacle to their study. The greatest difficulty rests with the large and fleshy species, such as the Boleti, Agaricini. It is not only the drying which must be done quickly and thoroughly, but part of your specimen will be in constant danger of being devoured by vermin. As soon as dry they require to be poisoned by some toxic fluid. Professor Peck, State botanist, uses the bichloride of mercury and alcohol. I would refer you to Peck's Report 24, page 43, where the preparation is given. The latest and perhaps the best article on the subject is that of Edwin A. Burt, of Middlebury College, Vermont, or the Botanical Gazette, Vol. XXV.

The bichloride mixture must be used freely before storing away for future reference.

C. G. Lloyd, of Cincinnati, Ohio, has great faith in preserving them in alcohol. He has the largest collection in his mycological museum of any in America.

The German collection is generally in the form of sections of the different parts, and put under pressure the same as flowering plants.

I have used tincture of quassia chips on some of the fleshy agaric, and found it equally as potent to the ravages of vermin. How I came to use quassia is that veterinary surgeons used it on cattle to destroy lice or other vermin. Thought I would try it on mushrooms, since if it would destroy vermin on cattle it might be equally effective on mushrooms.

The woody polyporeii are easily kept in boxes, first heated to I 40 degrees. to destroy insects and eggs.

The leaf parasites are easily prepared, that is, the puccinia pressed and dried with the host, like the flowering plant herbarium.

Moulds are best preserved on microscopic slides, dry or with some medium. 
In giving a list of fungi of a locality, it can not be considered complete without some systematic arrangement or classification, which these plants received by botanists.

The first classification, that was truly systematic, was made by Elias Fries, of Sweden, the same nativity of Carl von Linné, the father of the flowering plants. It is a peculiar coincidence that these two men, Fries and Linneus, both native of the same country, should be instrumental in first arranging these beautiful objects of creation into groups and families. Linneus, the father of Phænogamia botany, and Fries the father of Crytogamia botany. Fries first announced his system of classification in his "Systema Mycologicum," which formed the basis to all subsequent arrangement into groups and families. His system is still worth studying. But it has been greatly improved to meet the requirements of the more recent microscopical researches. Lindley Berkley, Cooke, DeBary, and Sach, each had their fancies. Fries first noticed a comparison in the formation of the spores, that of having them free resting on a basidio or stalk, and spores enclosed in a sack or pouch. This character forms the basis for a comparison. The former he classed under the name of sporifera, the latter under sporidifera. The spores of the former he called spores, the contents of the latter sporidia. This comparison is anomalous with exogens and endogens of the Phænogam division.

The sporifera group branches into four different classes, viz: Hymenomycetes, with the hymen exposed. Gastromycetes, with the hymen enclosed in a covering called a peridium. Coniomycetes, or dusty spores fungi, including rusty brands, etc. Hyphomycetes, thread fungi, moulds, etc.

Sporidifera has two subdivisions, Ascomycetes and Physomycetes.

This is really a very natural grouping with a few artificial exceptions. It was the system in vogue for many years. All authors on mycology made use of it. Cook, Berkeley called it 
perfect. Through the advancement of the science by DeBary, Ebighaus, and some German authors, they were not satisfied with the system, and constructed an improvement on a more natural basis, including even lichen, and discarding myxomycetes, or slime mould, placing the latter under the animal kingdom. Myogasters are proved to be fungi. Even DeBary himself admitted that the best place for them was amongst fungi. As for lichens, I do not see it possible to have them classed with fungi any more than to have them classed with algæ, for they are just as much aërial algæ as green fungi.

As late as I868, Professor Schwendener first propounded that all and every individual lichen was but a compound organ, consisting of an algæ base, with a fungal fructification (that is to say, symbiotic). Rev. J. M. Crombie, in his researches on the lichen gonidia question, came to the same conclusion that a lichen was half algæ and the other half fungal. But to accept lichen with fungi would destroy the primary definition of fungi in regard to the chlorophylle, which is present in the lichens and not in fungi. This at once upsets the placing of lichens in the rank of fungi.

Even Rev. J. M. Crombie has the sympathies of fungologists. The remark, in which his summary closes the subject, in which he characterizes as a "sensational romance of lichenology of the unnatural union between a captive algal damsel and a tyrant fungal master." The fructification of lichens is very similar to the pyrenomycetous and discomycetous fungi. Rev. M. J. Berkeley's definition for fungi is, viz: Cellular flowerless plants, nourished through their mycelium or spawn, living in the air, propagated by spores; naked or enclosed, destitute of green gonidia or chlorophylle, by which character they are distinguished from lichens. I do not see any advantage to adopt lichen as a group of fungi, since fungologists have sufficient material for many a life-work for ages to come. 
And to destroy that science would be an insult to such men as Tuckerman, Nylander, and other great lichenologists.

As there were many ways that lead to Rome, so there are many systems to get the particular species. Each author has his own peculiar fancy to get there.

The necessity of some kind of system is so apparent, that many attempts for the methodical arrangement of fungi were made even before Elias Fries; but his system was so superior to former ones, that no sooner had he published his Systema Mycologium, than all other arrangements became obsolete. Not many years elapsed before L,indly, of England, made improvements on his system, followed by Berkley and DeBary.

The classification of fungi is still an unsettled matter, yet the different systems have the same object in view, that is, of getting the name of each individual species.

The classification of Underwood and Cook in their "Century of Illustrative Fungi," is convenient and includes myxomycetes, which truly belong to fungi. They arranged them under six groups, viz:

I. BASIDIONYCETES.-Spores free on pedicels, includes nearly all the sporifera of the old classification.

2. ACOMYCETES. - Spores enclosed in sacs or asci, includes the sporidifera of the older classification. Morels, pezizæ, sphæriacei, powdery mildew, etc.

3. Phycomycetes.-Spores are similar to some of the algæ tribes. Zoospores and conidia, and sexually as zygospores or oospores. The potato rot and downy mildew on grape vines belong to this family.

4. Myxomycetes. - Slime moulds.

5. Saccharomicetes. - Yeast fungi.

6. SCHIOMYCETES.-Including unicellular bateria. 
To place the thousands of the different species to the rank of the fungi world, is a matter of no little difficulty. The only true basis is the physiological. The tree is known by its fruit so the fungi are really only known by the spores and texture. The Germans, Sachs, DeBary, Ebighaus, have each their fancy. If they can not make it suit by the natural physiological basis they are sure to put in artificial, like the colonel of a regiment who wanted his men all one size, so as to make a good appearance on dress parade-but could not get them-so those that lacked in size, made them wear high heels on the boots and those that were too tall, he had the heel of the boot removed. So it is with the classification of fungi-they do not always fit nature, and to complete a family he will add character to make it fit, 


\section{BASIDIOMYCETES.}

This group includes the Hymenomycetes, mushrooms, toadstools, or all gill-bearing fungi, Polyporei, etc., which will be given in order under the list.

Fungi of this class are divided into five natural groups :

I. Hymenomycetes.

2. Gastromycetes.

3. Uridineæ.

4. Ustilaginex.

5. Tremellineæ.

\section{GROUP I.-HYMENOMYCETES.}

Under this group are placed nearly all fleshy fungi, such as mushrooms, toadstools, shelves. They have a special open surface called the hymenium. The group is divided into five natural orders :

I. Agaricini. Hymenium with gills.

2. Polyporei. Hymenium with pores.

3. Hydnei. Hymenium with spines.

4. Thelephorei. Hymenium even, flattened surface.

5. Clavariei. Hymenium on an even club-shaped surface.

\section{Order I.-Agaricini, or Agarics.}

This natural order includes all gill bearing fungi, commonly called mushrooms, toadstools, etc. Berkeley in his outline of British fungi gives the following definition: "Hymenium 
inferior, spread over lamellæ or gills, which radiate from a common center, each of which may be separated into two plates."

It includes the following genera, viz :

I. Agaricus-Gills, not melting, edge acute; including all the subgenera which are elevated to the rank of a genus.

2. Coprinus-Gills deliquescent, spores black.

3. Bolbitius-Gills becoming moist; spores colored.

4. Cortinarius-Gills persistent; veil spider-web like, spores remaining for a time on gills.

5. Paxillus-Gills persistent, distinct from hymenophore.

6. Gomphidius-Gills branched, pileus top shaped, spores fusiform.

7. Hygrophorus-Hymenophores continuous with stem.

8. Lactarius-Gills milky.

9. Russula-Gills rigid, not milky.

Io. Cantharellus-Gills thick branched, obtuse edged.

II. Trogia-Gills venose, forked; edges channelled.

I2. Nyctalis-Gills fleshy, obtuse, often parasitic.

13. Marasmius-Hymenium dry, lamellæ thick.

I4. Lentinus-Pileus hard and tough, edge of gills serrated.

I5. Panus-Pileus tough, edge acute entire.

16. Xerotus-Gills tough and forked, edge obtuse.

r7. Schizophyllum-Gills split longitudinally.

I8. Lenzites-Corky, gills anastomosing.

\section{Genus.-Agaricus.}

The name is said to be derived from Agaria, a region of Sarmatia.

This is the largest family of the natural order and is characterized by the following distinguishing features: Gills membranaceous, scissile, acute at the edge, persistent, not deliquescing. Veil various, but never in the form of a spider-web, when universal. Spores falling off from the gills, not getting pulverulent on gills. Fleshy or membranaceous, not reviving when once dried up.

The genus is divided into five series, which are determined by the color of the spores, which are always constant in color, 
size, and shape. These are white (Leucospori), salmon or pink (Hyporhodii), brown or argillaceous (Dermini), dark purple (Pratellæ), black (Coprinarii). Each spore color series is subdivided into subgenera according to certain characters of the veil, gills, stem, etc. These subgenera are now elevated to the rank of a genus, and Agaricus is only retained in place of subgenus Psalliota which is dropped.

The following is a list of the Leucospori or white-spored Agarics.

\section{Amanita. Fr.}

This subgenus, or now considered as a good genus, heads the list of the white-spored Agaric, characterized by a universal volva or wrapper and a partial veil forming in some species an annulus. The volva enclosed the whole plant when young, and the remains of it are seen after development on cap and stipe.

C. G. Lloyd, of Cincinnati, Ohio, a colaborer in the study of fungi with me, has recently published a compilation of the Amanita family of the United States, has made use of Worthington Smith's arrangement of the groups of the genus Agaricus, viz :

\section{SERIES I.}

Pileus distinct from the fleshy stem.

Plant furnished with a volva $=$ Volvæ.

Plant without a volva, ring present, Annulæ.

Plant without volva or ring, Exannulæ.

\section{SERIES II.}

Pileus confluent with the fleshy stem.

Plant with a ring, stipe central, Armillæ.

Plant without a ring, gill attached to stem with a sinuate tooth, Dentr. Plant without a ring, gills decurrent, stipe central, Clivæ.

Plant with stipe eccentric, Excentræ.

SERIES III.

Stipe cartilaginous.

Gills not decurrent, pileus explanate, margin at first involute, Explanæe. 
Gills not decurrent, pileus campanulate, margin at first striate, Campanulæ.

Gills decurrent, pileus umbilicate, Umbilicæ.

This is a very ingenious improvement on the old spore color arrangement.

The gills are not adnate to the stipe except in one species, which is an Amanita with adnate gills. The gills are white, except one species.

This family is a very dangerous family on account of some of the poisonous species it contains; so it behooves us to get well acquainted with the different species, for they are so similar to the common edible mushroom that nearly all the accidental poisoning occurs by the use of some species of Amanita.

The principal characters, by which to determine an Amanita is, viz:

First, the spores must be snow-white, to find which take a fresh specimen, fully developed, cut the stem or remove it from the socket, for it is distinct from the gills. Place the cap with the gills downward on the surface of some dark glazed paper, and you will soon have plenty of spores deposited in the form of the radiate gills. Next make a section through cap and stem, which will tell you the biological structure, whether tough, brittle, or spongy ; also the character of the stem, fleshy or cartilaginous, hollow or solid. The stem will give you the best character, that is, the remains of the volva or universal wrapper, which you will find at the base. Some parts of the volva will also remain on the cap in the form of discrete warts. In all Amanita look and study the volva carefully. By getting acquainted with one good specimen for a type you will have mastered the Amanita family. 


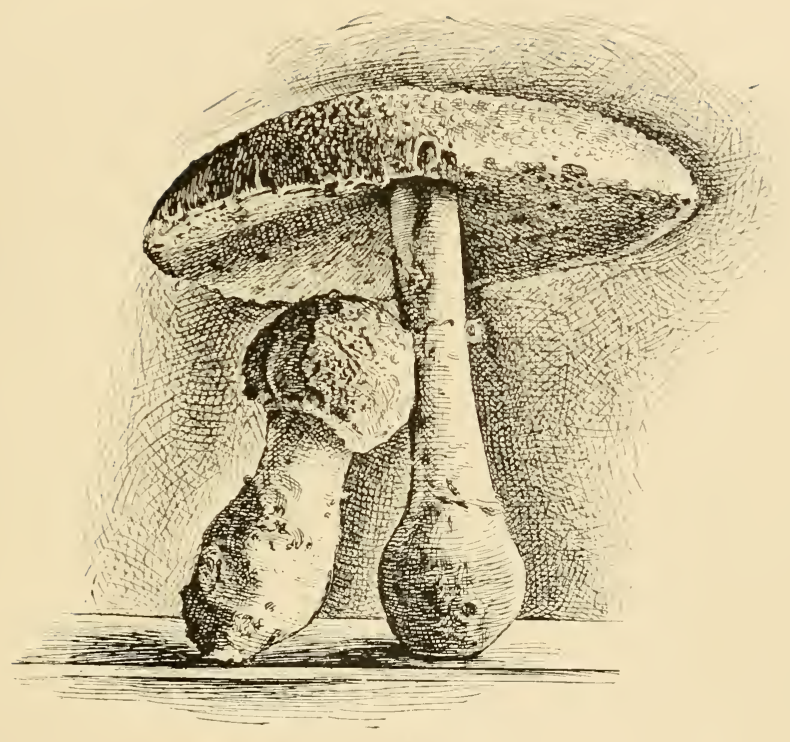

AMANITA MUSCARIUS. 



\section{Order I. AGARICINI.}

\section{SERIES I. LEUCOSPORI (white-spored).}

\section{GENUS I. AMANITA.}

The name of this family or genus is derived from Mount Amanus. Galen first brought specimen of a fungus from that locality. Gills free from the stem. The diagnostic character is the universal veil, called a volva, enveloping the young plant and distinct from the plant. All growing on the ground. All are suspicious as to the esculent qualities.

Twelve species of this family are represented in this catalogue.

\section{A. muscaria. Linn.}

Pileus, four inches or more broad, normally orange yellow or red, fading to white; convex, then flattened, covered with a pellicle, which is at first thick then thin ; glutinous, sprinkled with separating warts, fragments of the circumcissile rolva; margin striated, flesh white, under the pellicle yellow.

Gills, free but reaching the stem, broader in front, white, rarely becoming yellow.

Stem, four to six inches long, white, at first stuffed, with lax spiderweb fibres, some hollow; the adnate base of the volva forms an ovate bulb, which is emarginate with concentric ridges.

Ring, soft, torn, inserted at the apex of the stem. In old specimens the ring is generally destroyed.

This species is also called Fly Agaric by the English-speaking people. It is the type of the genus Amanita. Our species are not as brightly colored as the European are, but it is one of our grand species. Fig. I represents a young plant, with a fully developed one along side of it. Fig. 2 represents a full-grown one with top of pileus. 
Diagnosis. The beautiful discrete warts of pileus and the concentric rings of the bulbous stem. The rolva, a character of the family, is adnate to the stem and circumcissile.

Properties. Very poisonous, yet the Siberians use it as an intoxicant. The fungi are collected in the proper season and dried. The juice of the whortleberry, in which this fungi has been steeped, acquires the intoxicating property of strong wine. Some of the effects are similar to the indulgence of the Eastern haschisch. The natural inclinations become stimulated. The musician indulges in an incoherent song, the chatterer divulges all his secrets. Erroneous impressions of size and distance are a common occurrence, a straw in the way becomes a formidable object to overcome which a leap is taken high enough to clear a big barrel, etc.

Dr. Harold Lentz, in his "Schwaemme des Deutschland," says: "In the wild forest of Germany lived a man with his wife and child, who made fleshy fungi their sole diet throughout the whole year, using them fresh in their season, and dried during winter. He used all kinds indiscriminately if they had a good and appetizing appearance, and that he did not experience any harm from any of them. He being often warned not to be too free with the use of the different species, he accidentally got a Fly Agaric, which nearly cost him his life.

Cattle or wild animals very seldom eat it, except the reindeer in Siberia and Kamchatka. The wild reindeer are said to be partial to the taste of fleshy fungi, eat them without selection, and occasionally get a Fly Agaric. After a certain time they are stupefied and unable to walk; so as to be easily captured by tying their legs together, and keeping them as prisoners until the poison (Amanitine) is eliminated. If the animal is killed before the poison is eliminated, and used, it is said to have the same effect as if the toadstool had been used.

Erman, a German traveler in Kamchatka, says: "That his guide collected all the Fly Agarics, dried them and sold them to the Korans, which they used as an intoxicant. He was traveling with him in that country, always kept a few Fly Agarics with him, and whenerer he had a desire to get drunk, he would swallow a small piece with a drink of water, which would put him in a debauch for several days." If all those stories are true, the effect on those people must be quite different from the modus operandi on our race. Ebighaus, a German mycologist, doubts the truths of those people. He says they are a very deceitful race. They got Czar Alexis to try it, which caused his life, together with some French soldiers. I myself was rather skeptical at one time, but when I had the authority of such a man as Col. Geo. Kennan, in his "Tent-life 
in Siberia," who describes the same exhiloratory effect on the inhabitants of Siberia, it removed all doubts. There must be some peculiar idiosyncracy, or what we might call toleration, of the Amanita poison similar to opium on the Chinese and Turks. In medicine it is used by both schools, homeopaths and allopaths. The allopaths use it as cardiac depressant, night sweats, etc., but on account of care required in the administration, it is seldom uses. The alkaloid is generally used (the sulphate of muscarine). The homeopaths use it more freely, for the provings show a multitudinous application to sone of the most critical diseases.

This intoxicating property is imparted to all the secretions of the subject, especially the urine, which retains it for a long tinie. A man having been intoxicated one day, slept himself sober by the next, will, by drinking this liquor to some extent, become intoxicated again and again. By this means, with a few fungi to commence with, a party may shut themselves in their room and indulge in a week's debauch.

George Kennen says of a Korak marriage ceremony :

"After the conclusion of the marriage ceremony we removed to an adjacent tent, and were surprised, as we came out into the open air, to see three or four Koraks shouting and reeling about in an advanced stage of intoxication-celebrating, I suppose, the happy event which had just transpired. I knew that there was not a drop of alcoholic liquor in all Northern Kamchatka, nor, so far as I knew, anything from which it could be made, and it was a mystery to me how they had succeeded in becoming so suddenly, thoroughly, hopelessly, undeniably drunk. Even Ross Browne's beloved Washoe, with its 'howling wilderness' saloons, could not have turned out more creditable specimens of intoxicated humanity than those before us. The exciting agent, whatever it might be, was certainly as quick in its operation, and as effective in its results, as any 'tangle-foot' or 'bottled lightning' known to modern civilization. Upon inquiry we learned to our astonishment that they had been eating a species of the plant vulgarly known as toadstool. There is a peculiar fungus of this class in Siberia, known to the native as 'muk-a-moor,' and as it possesses active intoxicating properties, it is used as a stimulant by nearly all the Siberian tribes. Taken in large quantities it is a violent narcotic poison; but in small doses it produces all the effects of alcoholic liquor. Its habitual use, however, completely shatters the nervous system, and its sale by Russian traders to the native has consequently been made a penal offence by Russian law. In spite of all prohibitions, the trade is still secretly carried on, and I have seen twenty dollars worth of furs bought with a single fungus. The Koraks would gatler it for themselves, but it requires the shelter of timber for its growth, and is not 
to be found on the barren steppes over which they wander ; so that they are obliged for the most part to buy it, at enormous prices, from the Russian traders. It may sound strangely to American ears, but the invitations which a convivial Korak extends to his passing friend is not, 'Come in and have a drink,' but, 'Won't you come in and take a toadstool?' Not a very alluring proposal perhaps to a civilized toper, but one which has a magical effect upon a dissipated Korak. As the supply of these toadstools is by no means equal to the demand, Korak ingenuity has been greatly exercised in the endeavor to economize the precious stimulant, and make it go as far as possible. Sometimes, in the course of human erents, it becomes imperatively necessary that a whole band shall get drunk together, and they have only one toadstool to do it with. For a description of the manner in which this band gets drunk collectively and individually upon one fungus, and keeps drunk for a week, the curions reader is referred to Goldsmith's 'Citizen of the World, Letter 32. It is but just to say, however, that this horrible practice is almost entirely confined to the settled Koraks of Penzhinsk Gulf-the lowest, most degraded portion of the whole tribe. It may prevail to a limited extent among the wandering natives, but I never heard of more than one such instance outside of Penzhinsk Gulf settlement. "-Tent Life in Siberia.

The active principle called amanitine or muscarine is used in medicine for consumptive nigbt sweats. The homeopathic provings cover quite a number of symptoms.

Locality, Trexlertown cemetery, under a hemlock tree, chaparral ridgewood, etc. Not very abundant. Fuller's woods, near Catasauqua.

\section{A. spreta. Pk. Despised Agaric.}

Pileus, subovate, then convex or expanded, smooth or at first adorned with a few fragments of the volva, slightly striate on the margin, whitish or pale-brown.

Gills, close, reaching the stem, white.

Stem, equal, smooth, slightly pruinose above the white annulus, stuffed or hollow, whitish, finely striate at the top, inserted at the base in the rather large persistent membraneous, somewhat sheathing, volva; spores elliptical, .000t to .0005 inch long, .00025 to .0003 inch broad, generally containing a single large nucleus. 
Plant four to six inches high, pileus three to five inches broad, stem four to six lines thick. August._Peck's Report.

\section{A. Cæsarea. Scop. Cæsar's Mushroom.}

Pileus, hemispherical, expanded, margin striated, of a beautiful orange color, with a few remnants of the torn volva ; flesh white except near the cuticle, yellow.

Gills, yellow, free, straight.

Stem, tapering upwards, yellow, ring lax and not very persistent, volva sheathing the base of the stem; hollow, with cottony fibres.

Our species is not as robust as the European, and not so bright in color.

Cæsar's Agaric, or Orange Agaric. This is a large and showy Amanita. The yellow gills are the diagnostic character. It is also called the Fungorum princeps.

It is of a beautiful orange yellow color, not very abundant. All authors agree in attributing esculent properties. It has also been termed Cibus Deorum.

Specimens were found in woods northeast of Trexlertown, Pa., in Stephen's woods, and also in every open woods in the Valley in their season.

A. phalloides. Fr. The phallus-like toadstool.

Pileus, three to four inches broad, commonly shining white or sometimes light fuscous, ovate, campanulate at first then expanded, covered with a viscid pellicle; rarely adorned with the remains of the volva, which remains at the base of the stem and is split at the top.

Gills, white, free, ventricose, broad.

Stem, solid, bulbous downwards, hollow and tapering upwards, snow-white. Ring superior, white, reflexed. Volva more or less buried in the soil, entire or split, white.

Variable in color. With us it is white, sometimes fuscous. The olivegreen is very scarce, which is the prevailing color of the European species. 
Properties, very poisonous and dangerous. Often mistaken for the edible species of naucinus and campestris.

Locality. Is found in nearly every open woods in the Lehigh Valley and the State from midsummer to fall.

The amanita vernus is supposed to be the same, or a variety. The active principle is called phallin, and was isolated by Kopart, of Russia. Its modus operandi consists not of depressing the heart's action as much as muscarine, but of dissolving the red corpuscles of the blood and permitting the serum to escape through the alimentary canal. Weir Mitchell has proven that phallin is similar to the rattlesnake poison. It is an albuminoid, and classed under toxalbumen.

It is similar to the homeophathic proving of Lachesis. The fatal dose for cats and dogs is less than .or of a milligram, .00007 of a grain of body weight.

A good diagnosis between phallin poisoning and muscarine poisoning is to find out the time that intervenes between the eating and first toxic symptoms showing themselves. If only a few hours, say from four to five, you can expect phallin poisoning, together with the cholera symptoms, but when from eight to twelve hours intervene you may expect a case of muscarine poisoning and at once give a hypodermic of morphine one-fourth, with atropia $\frac{1}{20} \mathrm{gr}$.

Salt water is generally used in the preparation of mushrooms which in a measure might remove or coagulate the toxalbumin. There is no known antidote for phallin as there is of Amanita muscaria. Atropia and its allies does not counteract the poison. The only resource is by transfusion of the blood of some animal.

A. pantherina. D. C. Panther Toadstool.

Pileus, four to six inches broad, pale umber, convex, expanded, depressed in the center, with a viscous pellicle, margin striated, fragments of the volva in form of beautiful white warts scattered over the surface of the pileus.

Gills, free, reaching the stem, broad, shining white.

Stem, stuffed, then hollow, spider-web fibres within, attenuated upwards.

Volva, has an entire and obtuse margin at the base of stem. Ring, white membraneous, medial. 
This beautiful specimen was found in a dense thicket south of Trexlertown.

Name derived from the spotted pileus-like a panther.

Properties, very poisonous, and is considered as such by all authors.

Scarce, only met with it at the above-mentioned locality, September, I893, where it appears annually.

\section{A. solitarius. Bull. Solitary Toadstool.}

Pileus, convex, soon expanded, white, warty, even on the margin, flesh thick and white.

Gills, broad, reaching the stem, white, turning tan.

Stem, bulbous, rooting deep, bulb below the surface of the soil, or only even with the soil. Solid, white, mealy.

Volva, friable.

Ring, large, lacerated, hanging to the margin of the pileus.

This species is named solitarius on account of its growing singly or scattered in open woods. It is easily identified by the large bulb at the base of the stipe, which is conical and below the surface of the ground. The color is a dirty white, not as warty as the strobiliformis. Specimens were found in different parts of the county. Specimens were found near Wescoesville, between Trexlertown and Allentown, in an open woods, August and September.

\section{A. strobiliformis. Bull.}

Pileus, white, convex, expanded, pilliculose, the margin, which extends beyond the gills, even; warts hard, angular, white, closely adnate, flesh white.

Gills, rounded, free, white, becoming yellow.

Stem, six to seven inches high, thick, firm, solid, bulb thick and tubæform rooted, sometimes split. The greater part above the ground.

Ring, large, part forming a ring, and part remaining around the margin of the pileus.

This plant is named from the similarity of its undeveloped form to that of strobile of the pine. It is one of the largest. I have seen them eight = 
inches in diameter. They flourished in dry as well as during wet weather. The large above-ground bulb of the stipe is the most characteristic. The figure represents a full-grown plant.

Abundant throughout the county of Lehigh.

Properties. Suspicious. Some authors pronounce it edible while others doubt its esculent properties. Odor is not disagreeable, has a musty flavor. Color, white.

\section{A. rubescens. Per.}

Pileus, four to six inches, dingy reddish, becoming pale flesh color, tan, fleshy, convex, then plane, obtuse, moist but never viscous in rainy weather, and opague when dry, covered with unequal, soft, mealy, whitish, easily separating warts; margin even, when old slightly striated only in wet weather; flesh soft, white when fresh, reddening when broken.

Gills, nearly free, reaching the stem in an attenuated manner, shining white.

Stem, four to five inches long, solid, though soft within, attenuated from the thickened base, reddish squamules, becoming reddish. Ring superıo, large, white. There is hardly a trace of the friable volva.

The specific name is derived from the Latin rubesco, meaning red. The flesh is rusty red; it also turns red on being bruised.

Diagnosis. All the general character of the genus Amanita. Specific character is the reddish hue of whole plant. Volva friable, warts smaller than in Muscarius.

Properties. Some consider it poisonous, while others say if properly prepared it is edible. Berkeley considers it doubtful.

Locality, Spring Creek woods, near Trexlertown, where it grows abundant. August and September.

A. volvata. $\mathrm{Pk}$.

Pileus, fleshy, convex, expanded, striated on the margin, sprinkled with floccose scales, whitish disk, pale brown. 
Gills, close, free, white.

Stem, equal, tapering upwards, stuffed, minutely floccose, scaly, ringless, white.

Volva, large, firm, loose.

Plant two to three inches broad. One of Peck's Ananitopsis.

Volvate Amanita was found in the woods near the road leading from Fast Texas to Allentown, near Hartzell's schoolhouse.

\section{A. vaginata. Bull. Sheathed Amanita.}

Pileus, two to three inches broad, campanulate, color various from nearly white to fuscous or smoky : margin striated or sulcate, flesh white, thin.

Gills, free, shining white, ventricose.

Stem, hollow, with a spider-web fibrous living, attenuated upwards. Ring obsolete.

Volva, free, lax, sheathing the base of the stenl.

This is an exception to the typical Amanita since it is minus a developed ring. Peck made another genus for this species and the A. volvatus, and called it Amanitopsis. On account of the different colors this species assumes, there are a number of varieties. A. aurantiaca, A. fulva are the principals.

It is one of the most common of the exannulate amanita. It is one of the earliest and keeps on till late in fall. The name vaginatus is from the large membraneous sheath at the base of the stipe. All the other characters are in common with the exception of the annulus, which is wanting. The color of pileus is variable, from grayish-brown to grayish-yellow.

\section{A. farinosa. Schw. Mealy Agaric.}

Pileus, nearly plane, thin, flocculent, pulverulent, widely and deeply striate on the margin, grayish-brown or livid-brown.

Gills, free, whitish.

Stem, whitish or pallid, equal, stufted or hollow, mealy, 
subbulbous, the rolva flocculent-pulverulent, evanescent ; spores variable, elliptical ovate or subglobose, .00025 to .0003 inch long.

Plant about two inches high, pileus one inch to fifteen lines broad, stem one line to three lines thick. July to September.Peck's Reports.

This is the smallest of the genus. The whole plant is covered with a mealy covering, hence the specific name. It is exannulated, pileus grayish-white, margin striate. Gills free, white. Stipe white, dilated at the apex. A beautiful specimen.

Abundant in Kuhn's woods, where the specimen was found. August and September.

\section{A. adnata. Smith.}

Pileus, two and a half to three inches broad, pale buffyellow, fleshy, very firm, not brittle, smooth, somewhat moist, convex then expanded, buff beneath the cuticle, margin extending beyond the gills.

Stem, two to four inches high, stuffed, at length hollow, pale buff, fibrillose. Ring none. Volva lax, adnate, or almost obsolete, white, pubescent, remaining in woolly patches on the pileus; flesh white, firm, almost rigid.

Gills, truly adnate, crowded, white.

In woody places, among oak. Uncommon.-Stevenson's British Fungi.

Locality, Lehigh Valley.

\section{GENUS II. LEPIOTA.}

Nearly all species with adnate scales. Hymenophore distinct from stem; that is, the gills do not reach the stem. Scales adherent to pileus. The large species are edible. The receptacle or hymenophore distinct from the stem. Universal veil concrete with the epidermis of the pileus. Gills free, not sinuate or decurrent. Growing on the ground. 


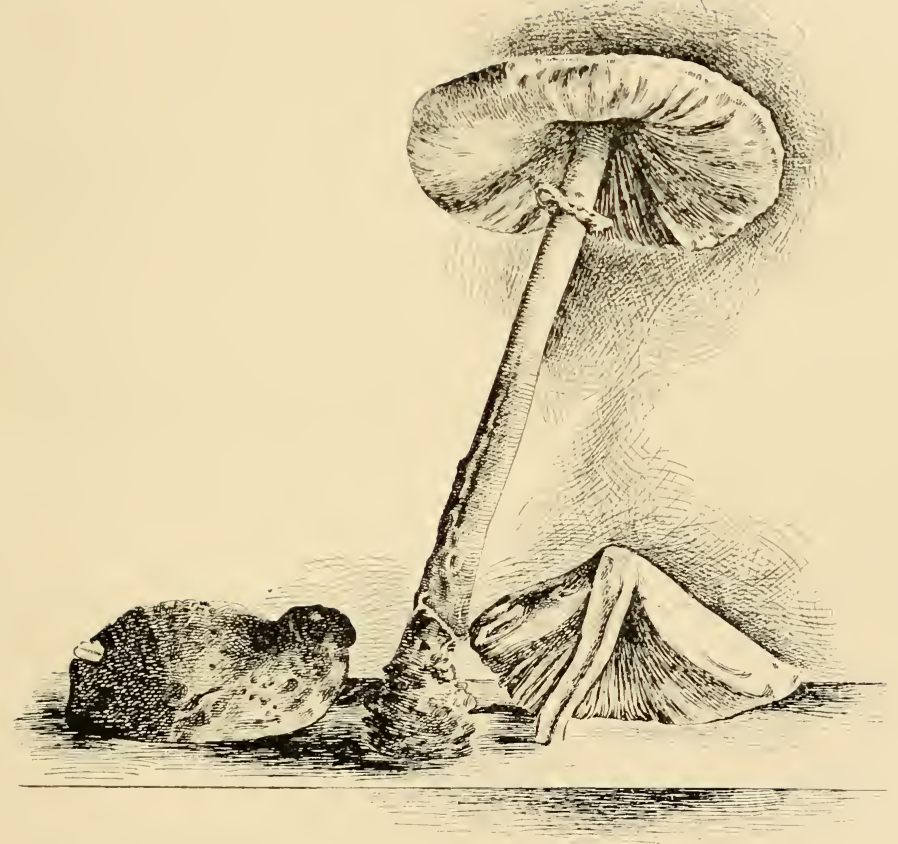

LEPIOTA PROCERUS. 

This family has about the same character as the Amanita family, with this difference: the scales, if any, are concrete with the epidermis of the cap, and is without a universal wrapper or volva, but has a veil forming an annulus.

A very interesting family. The parasol mushroom is the type, a delicious and wholesome fungi.

\section{I. procerus. Scop. Tall Mushroom.}

Pileus, four to eight inches broad, ovate or nearly cylindrical, campanulate, then flattened, with a prominent umbo fuscous or fawn color; cuticle is broken up into broad, thick, adherent scales, white beneath the scales; flesh white, soft, cottony, margin entire.

Gills, free, with a collar, crowded ventricose, soft, white.

Stem, cylindrical, with the exception of the bulbous base. Spotted with darker scales, deeply sunk into the pileus, hollow, stuffed with a cottony fibre.

Ring, distinct from the stem, movable up and down the stem, persistent. Easily recognized when once seen.

Parasol mushroom, from its shape, probably from the ring on the stipe being movable like that of an umbrella stick.

This is one of the few esculent mushrooms; it is perfectly safe and delicious, and easily identified by the adherent warts and movable ring $\mathrm{c} n$ the stem, texture soft and spongy.

Common in Spring Creek woods, near Trexlertown. It grows single, never cæspitose. Common along roadsides throughout the Valley.

\section{I. naucinus. Fr.}

Pileus, white, one to two inches broad, fleshy, soft, gibbows, or umbonate; the thin cuticle breaks up into granules.

Gills, free, soft, white, ventricose.

Stem, stuffed, at length hollow, attenuated upwards from the thickened base, fibrillose, pure white. 
Ring, superior, tender but persistent, adhering to the stem.

Prof. Peck in his Twenty-ninth Report of the State Museum, $N$. Y., makes a new species of the $L$. naucinus, on account of the oval spores and the smoother pileus. He calls it the Lepiota naucino:des, Pk., but it generally goes by the original name.

This is called the nnt mushroom, named from nux. naucinus. The whole plant is of a dirty white; the ring on stem is a good character; the white gills distinguishes it from cretaceus and campestris.

It is sometimes mistaken for campestris, which would be no harm, as both are edible and equally good.

Very abundant throughout the county ; same habitat as the Americana. Edible.

Specimen found in our lawn, and other localities in the Valley.

I. cristate1la. Pk. Little Crested Agaric.

Pileus, thin, convex, subombonate, minutely mealy, especially on the margin, white, the disk slightly tinged with pink.

Gills, close, rounded behind, free, white; stem slender, whitish, hollow; spores subelliptical, .0002 inch long.

Mossy places in woods. October.-Peck's Reports.

The crested Lepiota. The plant is white with light-brown scales.

Quite common along the grassy roadside. Small in comparison to percerus, etc. August.

I. rubrotincta. Pk. Red-tinted Toadstool.

Pileus, fleshy, soft, campantulate, expanded, cuticle red, scaly.

Gills, free, white.

Stem, hollow glabrous, somewhat bulbous, tapering upwards. Ring persistent.

Amongst old leaves. It is a beautiful specimen, but rare with us. The specimen is only partially developed. Found it growing on grassy lawns, and Heintz's open woods. 

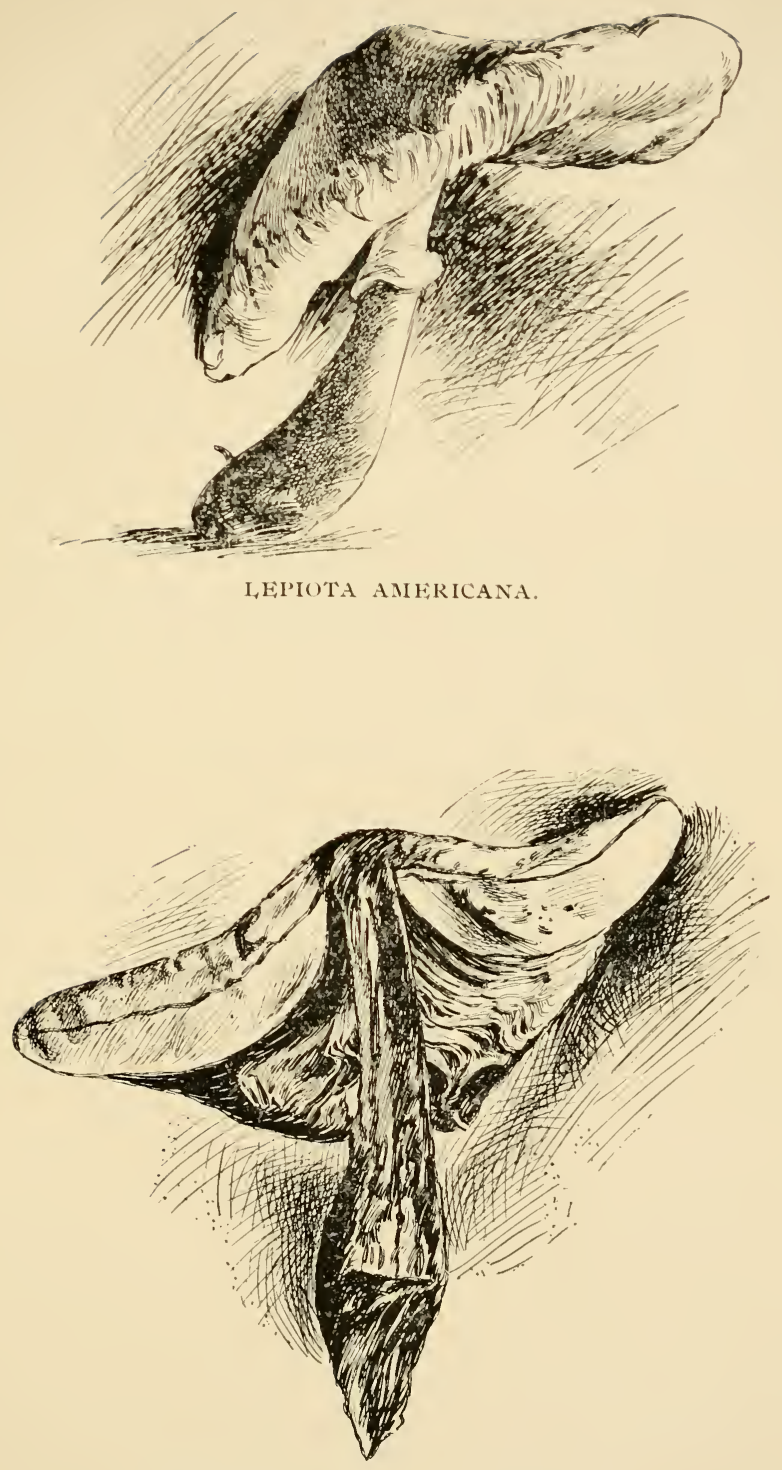

SEC'TION OF LEPIO'TA AMERICANA. 



\section{Americana. Pk.}

Pileus, four to six inches, convex, campanulate, expanded, umbonate, margin striated, adorned with beautiful reddish scales, dry ; flesh white, but dries, ferruginous.

Gills, free, white, ventricose.

Stem, glabrous, enlarged below into a subrentricose or spindle-shape bulb at the base. The ring is delicate in some specimens, but I have seen specimens where it was quite persistent.

This is truly an American species, not found in any other country. This is the pride of the family. There is nothing more beautiful than a cluster of this fungi. To look over the beautiful scaly pileus is a sight equally as fascinating as a covey of quails. It is generally met with along the roadside and on grassy lawns. It is known by the bulbous stem. The plant on drying turns a beautiful ferruginous color.

Odor musty, not recommended as edible. Habitat, grassy lawns, etc.

\section{L. granulosa. Batsch.}

Pileus, thin, convex or mealy plane, sometimes almost umbonate, rough with numerous granular or branny scales, often radiately wrinkled, rusty-yellow or reddish-yellow, often growing paler with age, flesh white or reddish tinged.

Gills, close, rounded behind and usually slightly adnexed, white.

Stem, equal or slightly thickened at the base, stuffed or hollow, white above the annulus, colored and adorned like the pileus below it, annulus slight, evanesent.

Spores, elliptical, .000I6 to .0002 inch long, .000I 2 to .ooor 4 inch broad.

Plant one to two and one-fifth inches high; pileus one to two and one-fifth inches broad; stem one to three lines thick.

Woods, copses, and waste places. Common. AugustOctober. 
This is a small species with a short stem and granular reddish-yellow pileus, and gills slightly attached to the stem. The annulus is very small and fugacious, being little more than the abrupt termination to the coating of the stem. The species was formerly made to include several varieties which are now regarded as distinct.-Peck's Reports.

\section{I. amianthina. Scop.}

Pileus, ochraceous, somewhat fleshy, convex then plane, somewhat umbonate, furfuraceo-granulose ; flesh yellow.

Stem, equal, slender, squamulose. Ring fugacious.

Gills, adnate, crowded, white then light-yellowish.

Smaller and thinner than A. granulosus, etc., from which it is distinguished by the adnate gills and yellow flesh, especially of the stem.

In woods. Uncommon. August. - Stevenson's British Fungi.

Lepiota Amianthinus, or flavofloccosus, of Batsch, on account of the beautiful yellow scales on the pileus and later granulose. I prefer the latter name, for the ring and veil are floccose granulose.

Abundant on mossy patches in open woods. Odor strong and acrid.

\section{Genus III. ARMILLARIA.}

The name of this family is derived from the latin Armilla, a ring, for the partial veil is in the form of a ring on the stem. The stem is fleshy and belongs to the fleshy stem group, with the gills and the gill-bearing part continuous with the stem. Only two species have been discovered growing in Lehigh County.

A. mellea. Flora Danica.

This species, called the honey toadstool, is abundant in our 


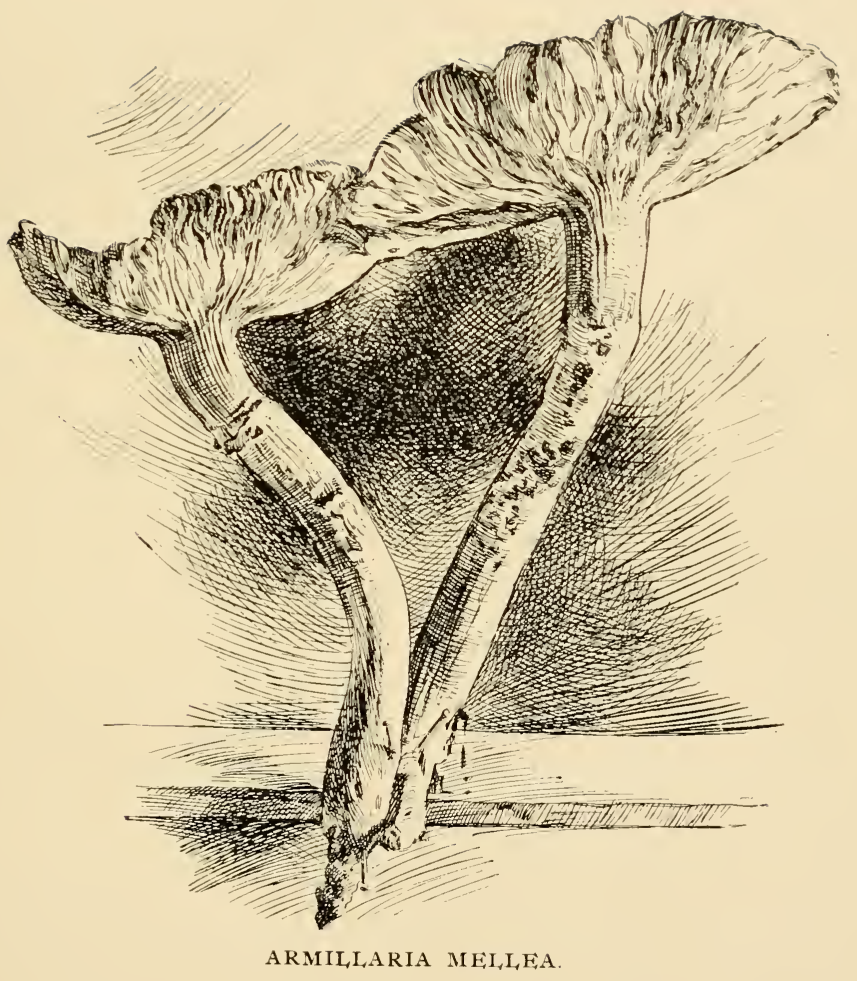



county, growing in profusion not only in low and damp situations, but on dry and elevated localities. The color is that of honey yellow, hence the name.

Pileus, fleshy, flesh white.

Gills, slightly decurrent and often tinged with yellow. When old they are tinged with brownish spots.

Stem, stuffed, then hollow, externally rigid, light yellow, woolly at the base, sometimes swollen at the base. Ring on stem characteristic near the top. In a raw state the honey toadstool is acrid and nauseous, but when boiled with salt it is said to be palatable. Grows around stumps late in fall.

This is one of the most common of the Agaricini, generally appearing in the fall and early winter. Almost every rotten stump has specimens surrounding it. It is supposed that the myceleum has the property of giving phosphorescent light on a dark night, frightening many a poor, superstitious victim.

\section{A. nardosmia. Ellis.}

The spikenard smelling toadstool grows on the ground in dense woods.

Pileus, thick and compact on the disk, brown spotted, flesh white.

Gills, crowded, white emarginate.

Stem, solid, sheathed by the veil, forming an annulus.

Kuhn's woods. October.

\section{GENUS IV. TRICHOLOMA.}

This is the first fleshy stem Leucospori fungi without a characteristic veil ; if present it is only in the form of an evanescent veil on the margin of the pileus.

Gills are continuous with the stipe and emarginate; that is, 
they are scooped at the attachment with the stem. The diagnostic characters are the fleshy stem, continuous with the flesh of the pileus or cap, and the gills sinuate.

All growing on the ground except a few species growing on rotten wood, reported by Prof. Peck.

This family is well represented in Lehigh County.

Fries divides the genus into different tribes, according to their biological character, viz :

I. The slimy Tricholoma.

2. The true Tricholoma.

3. The rigid Tricholoma.

4. The silky Tricholoma.

5. The spongy Tricholoma.

6. The watery Tricholoma.

T. terriferum. $\mathrm{Pk}$.

This is a beautiful, robust toadstool.

Pileus, convex, involute, wavy and involute on margin, viscid, pale yellow or whitish, generally with a good deal of dirt adhering to the top of cap on account of the sticky or viscid secretion on it, hence the specific name-earth-bearing Tricholoma.

Gills, are snow-white, rather close.

Stem, short and fleshy, slightly mealy.

Late in fall. Koch Island, near an abandoned ore bed.

\section{T. resplendens. Fr.}

Pileus, viscid, convex, expanded, pure white. This is the only white viscid species of Tricholoma.

Gills, nearly free, white.

Stem, solid white, two to four inches in diameter. 


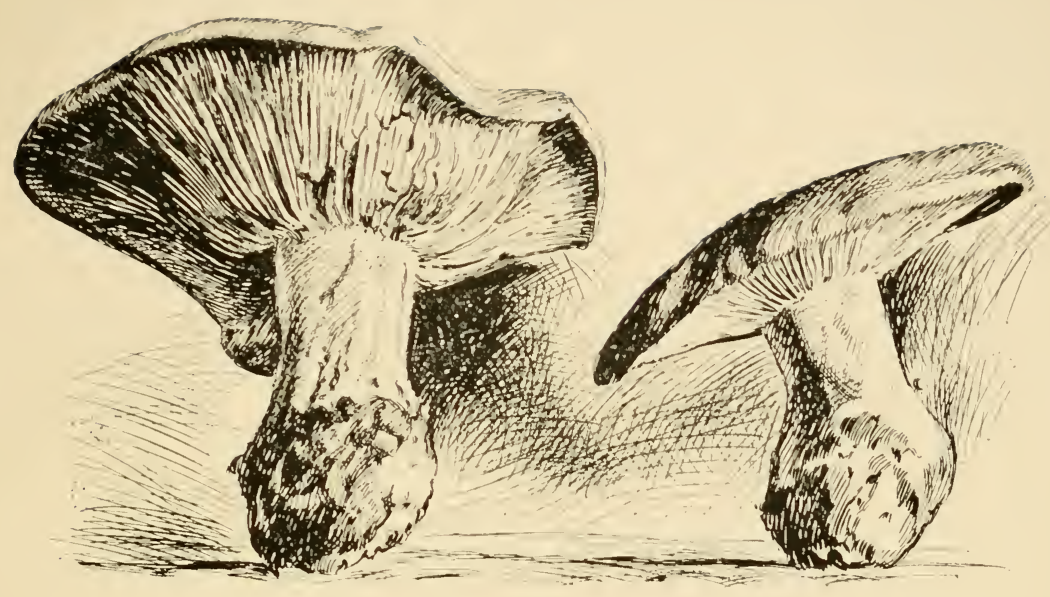

TRICHOLONA TERRIFERUM.

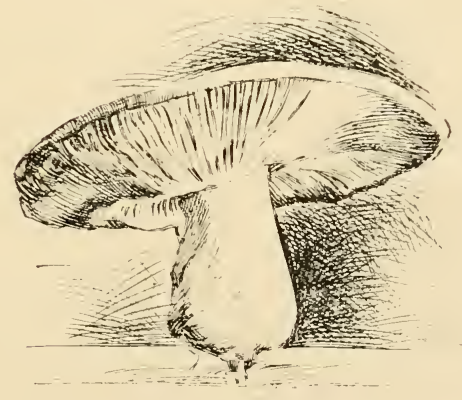

TRICHOLOMA PERSONATA. 

This is a pure white Tricholoma, very viscid. The habitat is in empty water ponds during a dry spell. It has a bitter taste and is not suitable for esculent purposes. In appearance it is not unlike a naucinus. Common in our woors.

On the ground in Kuhn's woods, near Cliapman's station. September.

T. sejunctum. Low.

Pileus, fleshy, convex then expanded, umbonate, slightly viscid, streaked with innate brown or blackish fibrils, whitish or yellowish, sometimes greenish-yellow, flesh white, fragile.

Gills, broad, subdistant, rounded behind or emarginate, white.

Stem, solid, stont, of ten irregular white.

Spores, subglobose, .00025 inch broad.

Pileus one to three inches broad; stem one to three inches long, four to eight lines thick.-Peck's Report.

A dark brown species, gills broad and frequently cracked. It is a robust-looking specimen. Common late in summer.

T. intermedium. $\mathrm{Pk}$.

Pileus, thin, campanulate, obtuse, glabrous, slightly viscid when moist, greenish-yellow, flesh white.

Gills, crowded, free or slightly adnexed, white.

Spores, broadly elliptical, .0002 inch long, .00016 broad.

Pileus two or three inches broad; stem one to two inches long, three to five lines thick.-Peck's Reports.

This specimen is called intermedium because it is intermediate between equestris and sejunctum.

T. terreum. Schaeff.

The earth-colored Tricholoma.

Pileus, flesh thin, convex, campanulate, floccose, scaly, mouse-color. 
Gills, adnexed, slightly emarginate, whitish at first then ash gray.

Stem, equal, solid to stuffed, whitish.

Pileus one to three inches broad.

This is named from its appearing like the color of earth. The color of pileus is a light fawn color with darker fibrils. It is a variable species in size, cespitose. You will find all sizes in a cluster, from a nickel to a silver dollar.

Woods and lawns; found nice specimens under a magnolia tree in Jos. Hertzog's lawn. Not poisonous.

T. personatum. Fr. Masked Tricholoma.

Pileus, compact, spongy, flesh thick, convex, with involute margin, of a pale, violet color. The color peculiar, when once seen can easily be identified.

Gills, emarginate, free, broad, close, white, with a peachblossom tinge.

Stem, same tint as the pileus and bulbous, villous, pruinose.

Pileus two to four inches, esculent, with an agreeable flaror.

This is the masked Tricholonı on account of its similarity to Tricholoma nudus.

On the ground, but late in the season, found them in December. Has no particular locality.

It is of a dull violaceous tint, growing in woods, lawns, and roadsides ; two to five inches broad. It has a musty flavor. Edible.

\section{T. nobile. $\mathrm{Pk}$. Noble Tricholoma.}

Pileus, very fleshy, spongy, yellowish white; flesh tinged with yellow; taste unpleasant.

Gills, broad, white, changing to yellow, rounded behind.

Stem, robust, floccose, pruinose.

Pileus two to four inches broad.

Kuhn's woods. 


\section{T. imbricatum. Fr.}

Pileus, fleshy, compact, dry, scales imbricated, from lightbrown to dark-brown.

Gi11s, white, becoming red or rusty-spotted.

Stem, white, with darker fibres.

Pileus two to four inches broad.

Odor mealy. Chaparral.

\section{T. subacutum. Fr.}

This derives its specific name from the acute umbo on the pileus.

Pileus, ovate, convex, expanded with an acute umbo, fibrillose with a silky lustre, white, turning to bluish-gray.

Gills, white, adnexed, slightly emarginate.

Stipe, stuffed or hollow, white.

Pileus, one to three inches.

Taste peppery ; but not poisonous. Kuhn's woods.

T. transmutans. $\mathrm{Pk}$.

The changing Tricholoma is convex, smooth, sticky, brownish, flesh white, odor farinaceous.

Gills, narrow, close, pale, yellow or white, changing to reddish when old, hence the name.

Stem, smooth, fleshy, silky, fibrillose, white, marked with reddish spots.

Size, two to four inches in diameter.

On the ground, Koch's Island. September to October.

\section{T. equestris. Linn.}

Pileus, fleshy, compact, convex, exrlanate, obtuse, squamulose, viscid, yellow near the margin. 
Gi11s, emarginate, free, somewhat crowded, whitish.

Stem, solid, dirty white or yellowish.

Pileus two to four inches broad.

Scarce. Found specimens in Bastian's open wood.

\section{GENUS V. CIITOCYBE.}

From Clitos, a declivity, and Cibe, a head.

This is the first genus with decurrent gills and a fleshy stem. Fries has the following definition: Universal veil, when present, is only frost-like, generally obsolete. Stem with a spongy pith, somewhat elastic. Margin more or less involute. The gill-bearing receptacle (hymenophore) quite continuous, owing to the apex of the stem being dilated. Gills running down the stem in an attenuated form, acute, never sinuate as in the Tricholoma. All growing on the ground, plant depressed in the center or (infundibuliform) funnel form. The thinner species are late, and stand low temperature. Many are remarkable for their fragrance. Few are edible.

The species are divided into two sections, the dry and watery (hygrophanous). To tell a hygrophanous specimen from a dry one is to make a section of the specimen. If it is watery and assumes a different color when dry, it is hygrophanous.

C. infundibuliformis. Schaff. Funnel-form.

Pileus, pale, tan color, fleshy at disc, convex, depressed, involute, margin even, flesh soft, white.

Gills, very decurrent, thin, close, soft, white.

Stem, thin and long, smooth.

Var. membranaceous, which is more spreading. 


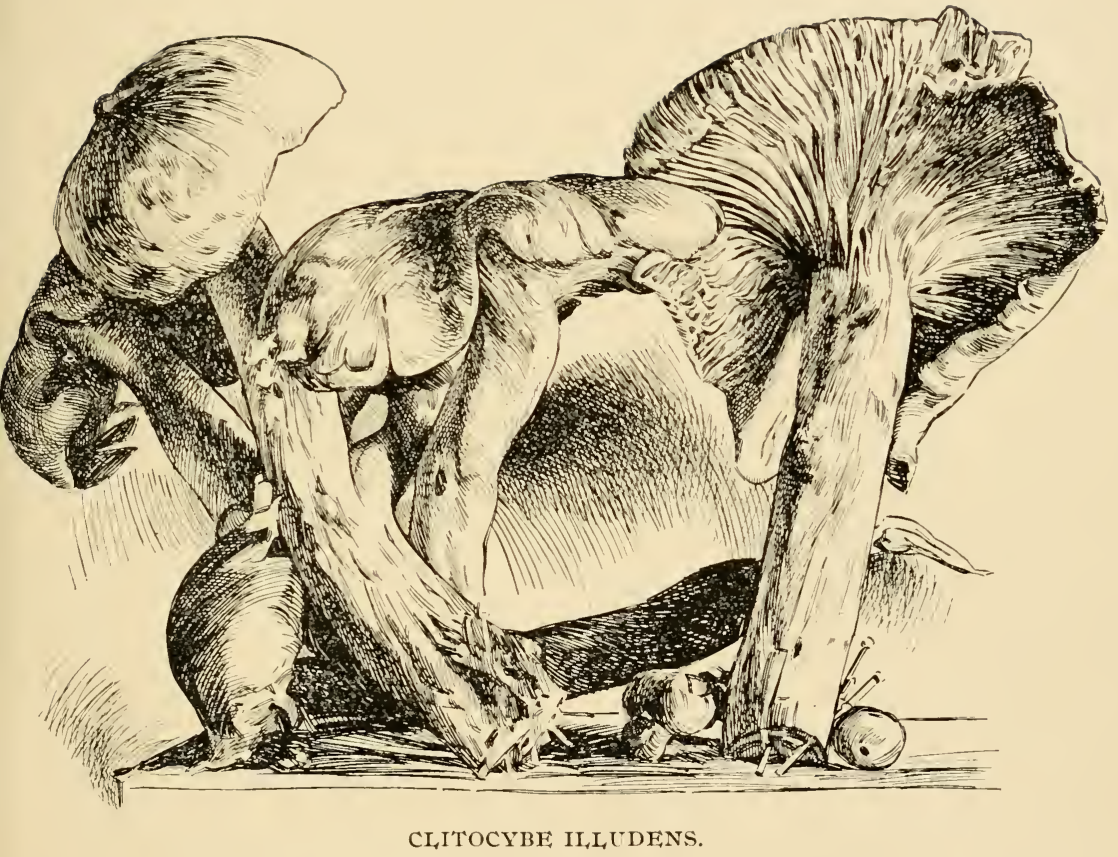



The funnel-shaped Clitocybe is a beautiful specinen growing almost in every open woods throughout our county. Very common in Spring Creek woods, etc.

It seems to be as common in Europe as with us.

C. multiceps. Pk. Manyhead Clitocybe.

This is a typical Clitocybe, having all the characters of the genus.

Pileus, fleshy, thin at the margin, convex, slightly moist in rainy weather, white.

Gills, white, decurrent, on one side adnate.

Stem, elastic, fleshy, solid.

Pileus one to three inches, growing in dense tufts. Many growing together, hence the specific name multiceps. It is rare. Only recorded by Falow and Macadams, of Massachusetts, and myself.

The Manyhead Clitocybe grows in clusters in yards and lawns. There are generally two crops in one season, one in early spring and another one late in fall. Of a dull white color. There are two localities in our village where they grow : one in the front yard of Tinsmith Heist and the other in the yard of Widow Gideon Yoder. Not poisonous.

\section{C. illudens. Schw. Shining Clitocybe.}

Pileus, of a beautiful yellow, can be seen from a distance, hence the specific name; convex, umbonate, spreading, deform from the cæspitose character.

Gills, decurrent, yellow.

Stem, long, firm, solid, smooth, tapering toward the base.

Pileus four to six inches broad; stem six to eight inches high.

This is a showy and magnificent plant. Not edible on account of its bitter taste.

The shining illudens is very common, growing all summer around stumps. A very beautiful golden yellow Agaric. It grows in clusters from fifteen to twenty in a cluster. 
C. monodelphus. Morgan. One Brotherhood Clitocybe.

Morgan, of Ohio, gives the following description of the One Brotherhood Clitocybe in "Mycological Flora of the Miami Valley, O."':

"Densely cæspitose. Pileus fleshy, convex, then depressed, at first glabrous, then scaly, honey color, varying to pallidbrownish ur reddish. Stipe elongated, solid, crooked, twisted, fibrous, tapering at the base, pallid-brownish or flesh color. Gills short, decurrent, not crowded, pallid flesh color. Spores white, a little irregular .0076 $\times .0055 \mathrm{~mm}$."

It may be easily mistaken for a ringless Armillaria mellea.

The One Brotherhood Clitocybe grows in clusters, from fifteen to twenty individuals springing up from a common point. The pilei are honey colored, with a few darker scales or disk, first described by A. P. Morgan, Ohio. Externally it has the appearance of an Ag. melleus. Appears about the same time as the melleus.

Grows in different localities in our county.

Specimens found in Albright's jungle, south of Trexlertown.

C. odora. Bull. Sweet-smelling Clitocybe.

This is easily recognized by its dull olive-green color of the pileus, and the sweet aniseed odor; convex at first, but soon becomes depressed in the center, making it saucer-shaped.

Gills, adnate, decurrent; a little paler than the pileus.

Stem, short, barely I $1 / 2$ inches long, thickened at the base.

The sweet-scented Clitocybe is the only species of the genus of dull green color, gills are whitish, has the odor of aniseed. Supposed to be esculent. Not very abundant. Habitat, open woods, Haus's Hill.

C. 1accatus. Fr. Shellac-colored Clitocybe.

Pileus, from one to two inches broad, almost membraneous, convex, then plane, depressed in the center. 
Gills, adnate, with a decurrent tooth, plane, flesh color to violaceous, at length mealy from the white spores, which are abundant.

Stem, tough, fibrous, stuffed, flexous, or crooked white villous at the base.

Var. amethysticus, whole plant violet blue.

The name of species is derived from lac, a resinous substance from a tree in the East Indies, which has a color similar to that of pileus.

This is a very perplexing species, since there are a number of varieties. It varies in size from specimens of three inches to so small that you can hardly believe it the same species. It also varies in color from the lac brown to almost purple; so the color of gills also varies. Abundant all over the county. Wherever I traveled I met with specimens.

C. ochropurpurea. Berk. Clay-purple Clitocybe.

This species is named from the light clay-colored pileus and the purple gills.

Pileus, convex, fleshy, compact, clay-colored, sometimes tinged with light purple around the margin, which is involute. There are some odd forms of the pileus of this species, so as to be almost unrecognizable.

Gills, purple, but some white with the white spores, decurrent, broad, distant.

Stem, robust, white, tinged with violet, solid, fibrous.

This is purely an American species and nearly related to laccatus. The pileus is of a light ochraceous color, and the gills are light purple, hence the specific name. Some seasons it seems to be abundant, while in others it is more rare. Old specimens have the gills whitened with the white spores.

\section{C. ditopus. Fr.}

The Two-legged Clitocybe, or stems growing together.

Pileus, two inches or more broad, convex, expanded, moist, ash-grey. 
Gills, adnate, crowded, at length turned up so as to make gills decurrent.

Stem, many growing together, from two to half a dozen.

Iinesite woods.

C. fragrans. Fr. The Fragrant Clitocybe.

Pileus, convex, involute, yellowish white, kind of watery, strong smell of aniseed or paragoric.

Gills, adnate, attenuated down the stem, crowded, white. Stipe, hollow, villous at the base.

Found in Elias Lichtenwalner's woods, which has since been cut.

C. media. $\mathrm{Pk}$. Between Clitocybe.

Pileus, grayish brown, convex, expanded, margin involute, flesh mild.

Gi1ls, broad, white, decurrent or adnate.

Stem, solid, elastic, paler than the pileus between nebularis and clavipes.

IIinesite woods.

C. nebularis. Batsch. The Smoky Clitocybe.

Pileus, cloudy, convex, involute, expanded, dry, covered with a greyish prunosity, flesh compact, white.

Gills, decurrent, crowded, pale white.

Stem, sordid like the pileus, thick, stout, obclavate fibrillose striate.

C. cyathiformis. Fr. Saucer-form or Cup-shaped Clitocybe.

Pileus, dark umber, plane, depressed when young, when old funnel-form.

Gills, deeply decurrent, crowded, cinereous, fuscous.

Stem, short, dark umber.

Not common. Haus's Hill. 
Genus VI. COLLYBIA. Fr. Syst. Myc.

Stem fistulous, cartilaginous, or stuffed with a pith, and coated with a cartilaginous cuticle, rooting. Pileus fleshy, smooth, margin at first involute. Gills adnate or nearly free.

Epiphytal on wood and leaves; not shriveling or drying, but rotting.

Fries divided this family into two series, according to the color of the gills: I. Gills white; 2. Gills cinnereous. The white-gilled Collybia were again divided according to the condition of stem : I. Stem striated or ribbed; 2 . Stem clothed with a downy coat; 3 . Stem naked or smooth.

C. velutipes. Curtis. Velret-stem Collybia.

Pileus, one to four inches broad, tawny yellow, fleshy at the center, thick on the margin, viscid or sticky when moist.

Gills, rounded behind, slightly adnexed, broad, tan or pale yellow.

Stem, cartilaginous (which they must be under this genus), hollow, umber, with a nice velvet coat.

This is a common intruder on old and young stumps, attacking both decayed and green wood. It has a peculiar liking for the Eelanthus glandulosus tree. You will frequently find clusters of it growing out of a crack from a hardy tree. It is the hardiest of the tribe. It will grow during the cold days of early winter.

C. platyphyllus. Fr. Broad-gilled Collybia.

Pileus, three to four inches broad, fuscous to greyish, streaked with darker fibrils, watery when moist, flesh white.

Gills, obliquely truncate behind, slightly adnexed, I $2 \mathrm{~mm}$. ( $1 / 2$ in.) and more broad, distant, soft, white.

Stem, short and thick, striated, root blunt, common in chaparral woods. 
This is a beautiful specimen, from dark-brown to a light fawn color, generally of a good size. I have found specimen measuring six inches in diameter. Stipe stout and cartilaginous, etc. Habitat, open woods.

\section{C. radicatus. Rehl. Rooting Collybia.}

Pileus, three to four inches broad, fuscous, olivaceous to light yellow, glutinous when wet, umbonate.

Gills, attenuated with a decurrent tooth, ventricose, shining white.

Stem, four to six inches high, smooth, glossy, striated sulcate, rooting deep with a spindle-shaped root.

This is a common toadstool found nearly in every open wood in Pennsylvania, also in lawns.

The diagnostic character is the long tapering root. It is easily recognized when once known.

\section{C. confluens. Pers. Tuffed Collybia.}

Pileus, barely over an inch broad, pale tan color, crowded, convex, plane, flaccid, margin thin, slightly striated.

Gills, free at length, remote from the stem, very crowded, narrow, linear, flesh color, then white.

Stem, clothed with a dense villous down, hollow.

Growing in woods on leaves. Common in Spring Creek woods.

C. dryophylus. Bull. Oak-loving Collybia.

Pileus, bay brown, one to two inches, convex, plane, depressed.

Gills, free, with a decurrent tooth, crowded, narrow, white. Stem, yellowish, cartilaginous, smooth, very fistulous.

Common on oak leaves.

Genus VII. MYCENA. Fr. Syst. Myc.

Stem fistulous, cartilaginous. Pileus, small, membraneous, at first conico-cylindrical by reason of the margin being 


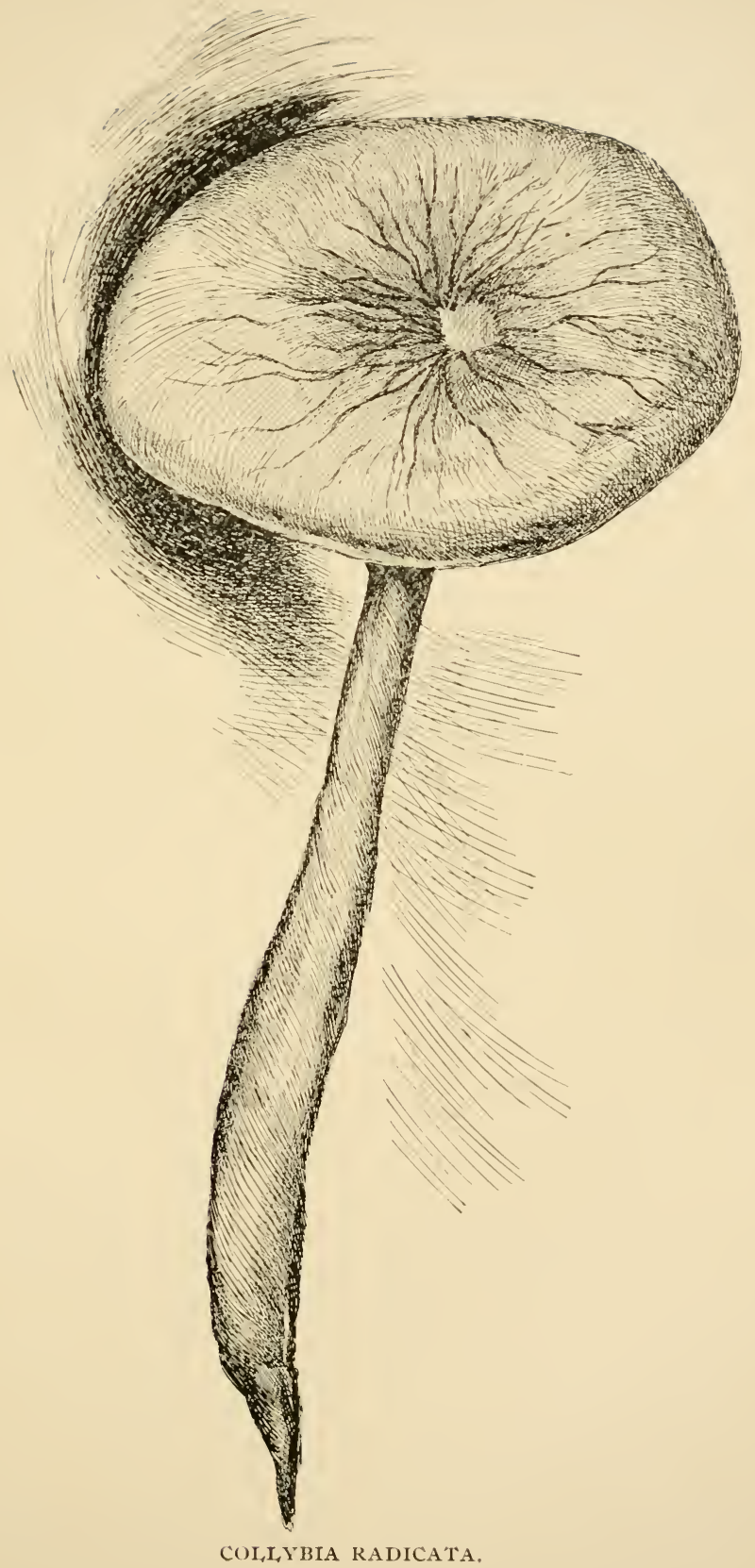



straight and pressed close to the stem. Gills not decurrent, distinguished from the other cartilaginous by the margin of the pileus, never involute, and from the pileus being umbonate. I have only few determined species; on accomnt of their small size they are as a general thing orerlooked.

\section{M. galericulata. Scop. The Peaked Mycena.}

Pileus, campanulate, expanded, margin striated to the peak or umbo, of a greyish color.

Gills, adnate with a tooth, connected by veins, whitish by flesh color.

Stem, rigid, polished, even fusiform, strigose rooted, on rotten stumps.

This is a common fungus during the warm summer season. It grows in heavy clusters on rotten stumps. Common from August to December.

The color of pileus a dirty white or greyish, lighter towards margin.

\section{M. rugosa. Fr.}

Pileus, darker and smaller than the galericulata, conicocampanulate, expanded, corrugated, always dry.

Gills, adnate, with a tooth, united behind with a collar, distant, connected by veins.

Stem, short, tough, rooted with a hairy base. Common on stumps late in the season.

This is one of the largest of Mycena, not as abundant as the galericulatus (Scop). Its habitat is near stumps and on decaying parts of it. Specimen found on chaparral ridge-woods.

M. corticola. Schw. Bark Mycena.

Pileus, thin, hemispherical, umbilicate, striate.

Gills, adnate, uncinate, broad, pallid.

Stem, short, curved, mealy.

Common on horse-chestnut bark. 
Genus VIII. OMPHALIA. Fr. An Umbilicus.

Stem cartilaginous, fistulous, but having the tube often stuffed with flocci, thickened upwards like a trumpet into the pileus. Gills truly decurrent. It is separated from Mycena and Collybia by the decurrent gills. The pileus is generally umbilicate, funnel-shaped. The species are $=$ well marked, are small in size, none larger than one inch broad. I have but a few species to record. No doubt on account of their small size they are often overlooked.

o. umbellifera. Linn. Umbel Omphalia.

Pileus, one-half inch broad, whitish, convex, plane, broadly obconic, slightly umbilicate, rayed with darker striæ.

Gills, decurrent, triangular, very distant.

Stem, short, dilated towards the apex.

Commonly growing on stumps.

O. pyxidata. Bull. The Box Omphalia.

Pileus, as much as 2.5 cent. ( I in.) broad, very hygrophanous, trick-rufescent or rufous-fuscous when moist, becoming pale, opague when dry, membranaceous, pelincid, umbilicate then infundibiliform, when moist smooth, sometimes at the margin, sometimes wholly radiate, striate, when dry flocculose or slightly silky.

Gills, decurrent, somewhat distant, distinct, narrow, but broader at the middle, flesh color, thin, pale yellowish.

Stem, thin, cartilaginous, fistulous.

A small brown toadstool, growing in grassy lawns, almost hidden by the grass and weeds.

O. campane1la. Batsch. Bell Omphalia.

Pileus, membraneous, convex, umbilicate, striate, hygrophanous.

Gills, decurrent, arcuate, yellowish.

Stem, fistulose, clothed with down.

A small species found in different localities in the Valley. 


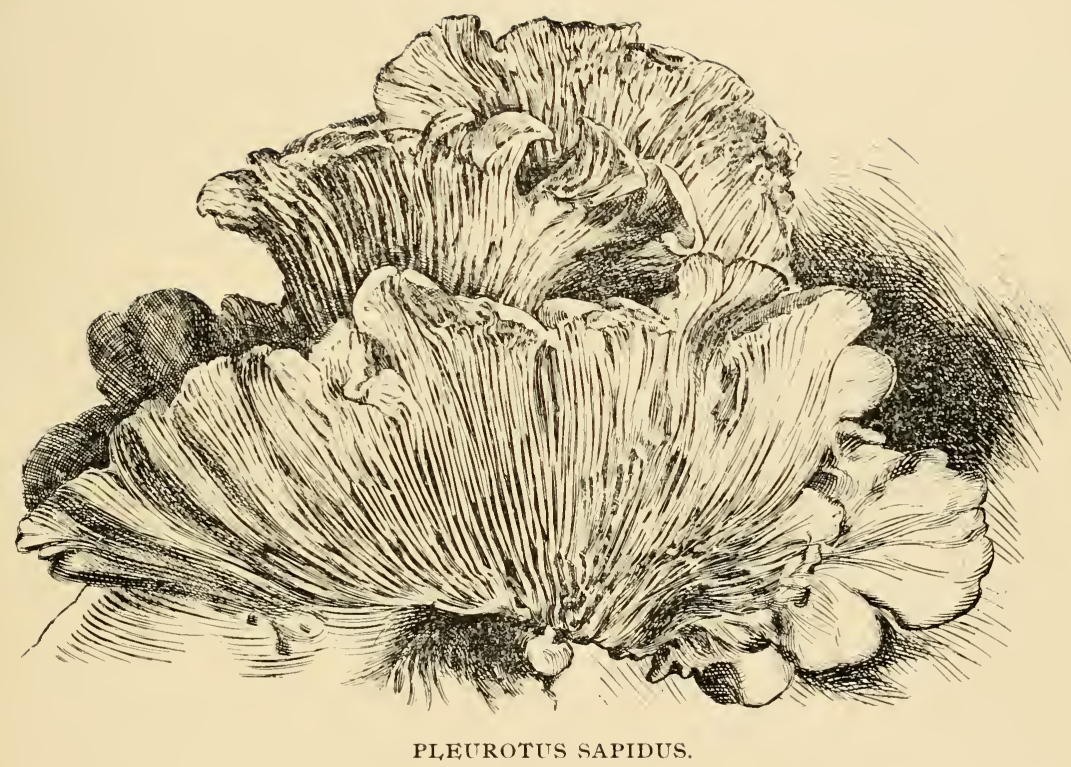





\section{GFnus IX. PLEUROTUS. Fr.}

This genus is very easily determined by the excentric, lateral, and without a stem, but must have the characters of an Agaricini and white spores. We have many fungi that are excentric, lateral and without a stem, such as many Polyporei.

The Pleuroti are easily distinguished from the two preceding genera by their mostly growing on wood. Our Pleuroti all grow on wood, found indiginous thus far.

Fries divides the Pleuroti unto three sections: First, the excentric, where the stem is surrounded by the gills, but one side shorter than the other, that is, the stem is not central. Second, where there is a stem, but the gills and pileus are all on one side. Third, Resupinati, without a stem, or only a trace, with gills turned toward the light.

\section{P. sapidus. Kalch. Sapid Pleurotus.}

This is the most common Pleurotus growing in our country. You will meet with it on all kinds of decaying logs; willow and oak seem to be preferred.

Pileus, excentric, expanded, from white to smoky brown.

Gills, broad, decurrent, white.

Stem, firm, straight or curved, white or whitish.

This is a variable species; it deviates from the type in having the spores turn slightly pinkish after being shed on white paper, but on dark paper they are white.

This is nearly allied to the cosmopolitan Ostreatus, with which it is confused. The color of spores is the principal diagnosis. The spores of specimen are a light pink on white paper and white on dark paper, whereas the Ostreatus is white o11 white and dark paper. There are a variety of forms. Some have an entire margin white, others are beautiful lobed.

Specimen was procured from an old Elanthus glandulosus stump.

More abundant in the fall, but is also met early in June. Edible. 


\section{P. Serotinus. Fr. Late Agaric.}

This late Agaric you can find on old logs in dense woods. It rarely makes its appearance before late in September, and good specimens can be found in December. It is a beautiful species. The stem part is adorned with dark-brown sputs on a yellow base. - Peck considered it a separate species and named it P. serotinoides, $\mathrm{Pk}$.

\section{Agaricus serotinoides. $\mathrm{Pk}$.}

Pileus, fleshy, one to three inches broad, compact, convex or nearly plane, viscid when young and moist, dimidiate reniform or suborbicular, solitary or cæspitose and imbricated, variously colored, dingy-yellow, reddish-brown, greenishbrown or olivaceous, the margin at first involute.

Gills, close, determinate, whitish or yellowish.

Stem, very short, lateral, thick, yellowish beneath and minutely tomentose or squamulose with blackish points.

Spores, minute, elliptical, .0002 inch long, .000I inch broad.-Peck's Reports.

The late agaric is truly a late fungus, not appearing before frost sets in. It is a beautiful specimen. The stipe is the beautiful part of it-of a beautiful golden yellow, speckled with darker dots. You will meet with it growing on old logs from September on to January. I have found well-preserved specimens in the latter part of December.

Found in Albright's jungle, near mill race.

P. niger. Schw. The Black Agaric.

This is the smallest of the Pleurotus and is resupinate-that is, with the gills facing the light. You will meet with it all summer on decayed, moist limbs, like so many black shirt buttons.

Jungle, Trexlertown. 
P. atrocœruleus. Fr. Black-blue Agaric.

This specimen is rather rare.

Pileus, thin, one-half to three-fourth inch, obovate, reniform, plane depressed, smooth, grayish-blue.

Gills, determined, distant, grey.

Stem, marginal, short, distinct.

Found species growing on mulberry trunk.

P. ostreatus. Fr. The Oyster Mushroom.

Pileus, two to four inches broad, soft, convex or slightly depressed behind, subordinate, often cæspitosely imbricated, moist, glabrous, whitish cinereous or brownish, flesh white.

Gills, broad, decurrent, subdistant, anastomosing at the base, white or whitish.

Stem, when present, very short, firm, lateral, sometimes strigose, hairy at the base.

Spores, oblong, white, .0003 to .0004 inch long, .00016 broad.-Peck's Report.

This species is frequently mistaken for the sapidus. They are so similar in external appearance that the only character is the pinkish spores on white paper. For many years I took the sapidus for this species. It was only after getting at the spores on white paper that I determined its proper place. It is scarce in Lehigh County. The only locality is on an elm stump, Spring Creek woods.

\section{SERIES II. HYPORHODII OT RHODOSPORAE.}

Spores salmon or pink color.

The genera under the pink-spored Agaricini are arranged in the same manner as the preceding white-spored series. They are not near so abundant as the preceding species. The gills are at first white, but soon turn to the pink color of the spores.

The term is derived from $H y p o$, diminutive, Rhodos, rose. 
Genus X. VOLVARIA. Fr. Volva, a wrapper.

Rosy-spored. Universal veil free, persistent, distinct from the epidermis of the pileus (constituting a volva). Hymenophore distinct from the stem. The Volvariæ are, as it were, Amanitæ with rosy spores, but they are more nearly related to the Plutei and the Psalliotæ. Gills rounded behind and free, ventricose.

Volvaria corresponds with Amanita. The species appear early in the year. They grow chiefly on rotton wood or in rich mould or manured ground; hence they are more frequent in gardens, hothouses, etc., than in woods. Some are said to be edible, but they soon acquire a disagreeable taste from the rapidity with which they decay.-Stevenson's British Fungi.

\section{V. bombycinus. Schaff. Silky Volvaria.}

Pileus, three to eight inches broad, wholly white, fleshy, broadly campanulate, everywhere silky.

Gills, free, broad, ventricose, crowded, light at first, but soon flesh color.

Stem, three to six inches long, thickened toward the base, with a large volva attached to the base.

The silky Volvaria, from bombyx, silk. Of a beautiful silky lustre. It is the first of the Hyporhodii. It is at first entirely enclosed in a volva, and is deceptive. Easily mistaken for an Amanita. It is to hyporhodii or the salmon-colored spore tribe what Amanita is to leucospori or whitespored tribe.

The silk agaric is one of the most interesting specimens of the family. It is wonderful to watch the exist of the hymenial parts out of the volva -like unto a chick out of the egg.

Found specimen on a hickory log (Carya), Spring Creek.

V. parvulus. Wein. The Small Volvaria.

This is the smallest of the series, growing in grassy yards, but very characteristic. 


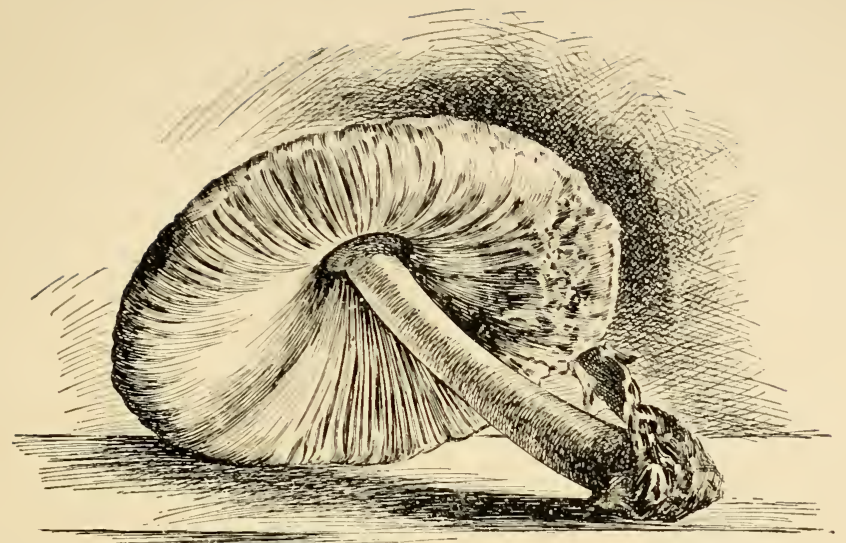

VOIVARIA BOMBYCINIS

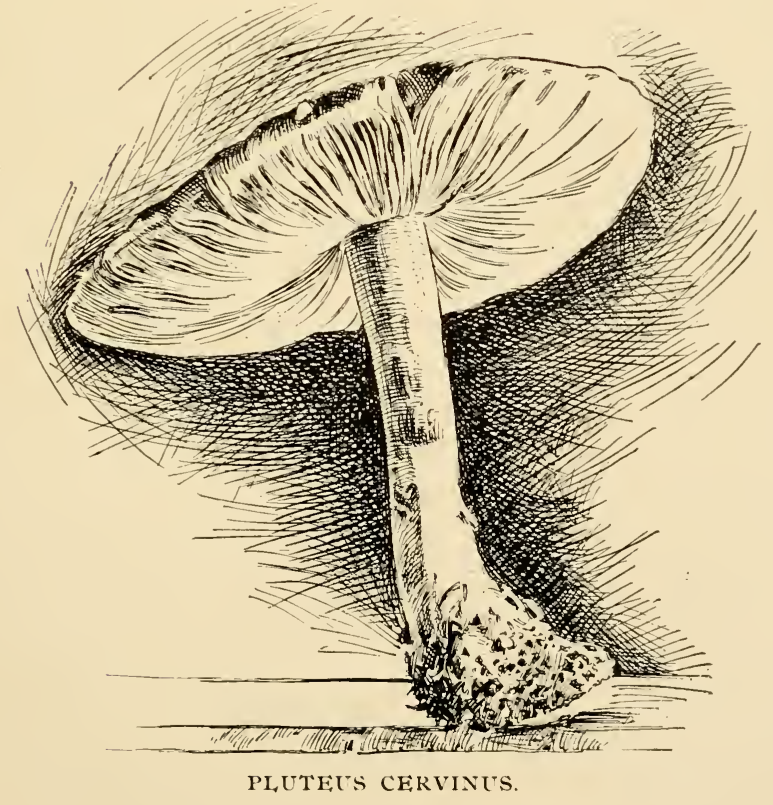



Genus Xi. PIUTEUS. Fr.

Rosy-spored, without a volva or ring. Gills free from the stem, white at first, then flesh color. Pluteus would agree with Lepiota, if we consider the prunosity as a universal veil.

P. cervinus. Schaeff. Fawn-colored Pluteus.

Pileus, three inches or more, campanulate, expanded, viscid in wet weather, smooth, except a few dark fibrils when young, margin entire, flesh soft and white.

Gills, free, separate from the stem, ventricose, crenulate, white at first, then flesh color.

Stem, solid, firm, white, spread over with a few dark fibrils, generally crooked.

Named from cervus, a deer. The top of pileus is colored like a young deer.

This is quite common in our vicinity, growing on old stumps, fence rails, etc. The flesh is pure white, gills also white at first, but soon becoming salmon color from the sliedding of spores. It can be found in early summer until late in autumn.

\section{P. granularis. $\mathrm{Pk}$.}

Pileus, convex, then expanded, subumbonate, rugosewrinkled, sprinkled with minute blackish granules, varying in color from yellow to brown.

Gil1s, rather broad, close, ventricose, free, whitish, then flesh-colored.

Stem, equal, solid, pallid, or brown, nsually paler at the top, velvety with a shorter close plush.

Spores, subglobose, about .0002 inch in diameter.

Plant two to three inches high, pileus one to two inches broad, stem one to two lines thick.-Peck's Reports. 
P. eximius. Smith.

Pileus, fleshy, campanulate when young, expanded, beautiful fringed on the margin, larger than the cervinus.

Gills, broad, ventricose, free, white at first, then rose-color, flesh white, firm.

Stem, thick, solid, fribrillose.

On sawdust and icehouses.

P. nanus. Fr. The Dwarf Pluteus.

Pileus, one inch, umber, darker at the disk.

Gills, free, flesh color.

Stem, solid, attenuated at the base.

On old logs. Jungle.

\section{Genus Xit. ENTOLOMA. Fr.}

Entos, within; loma, fringe.

Probably referring to the inner character of the veil of which there is only a trace. Pink spored. No distinct veil. Pileus fleshy, margin incurved. Gills emarginate, same as in Tricholoma in the white-spored series. Spores, so far as examined, angular. Entoloma is analogous with Tricholoma. All grow on the ground.

\section{E. clypeatus. Linn.}

Or nearer Entoloma strictior, Pk. From strictus, erect.

This is rather a perplexing species since the characters come so near clypeatus as to be hardly necessary to make a new species.

It is a beautiful plant, rosy-spored gills. The whole plant is beautifully regular and symmetrical. The principal diagnosis is the extensive white mycelium on base of the stipe. It is a genuine Entoloma.

Found in woods near Ziegel's Church. 


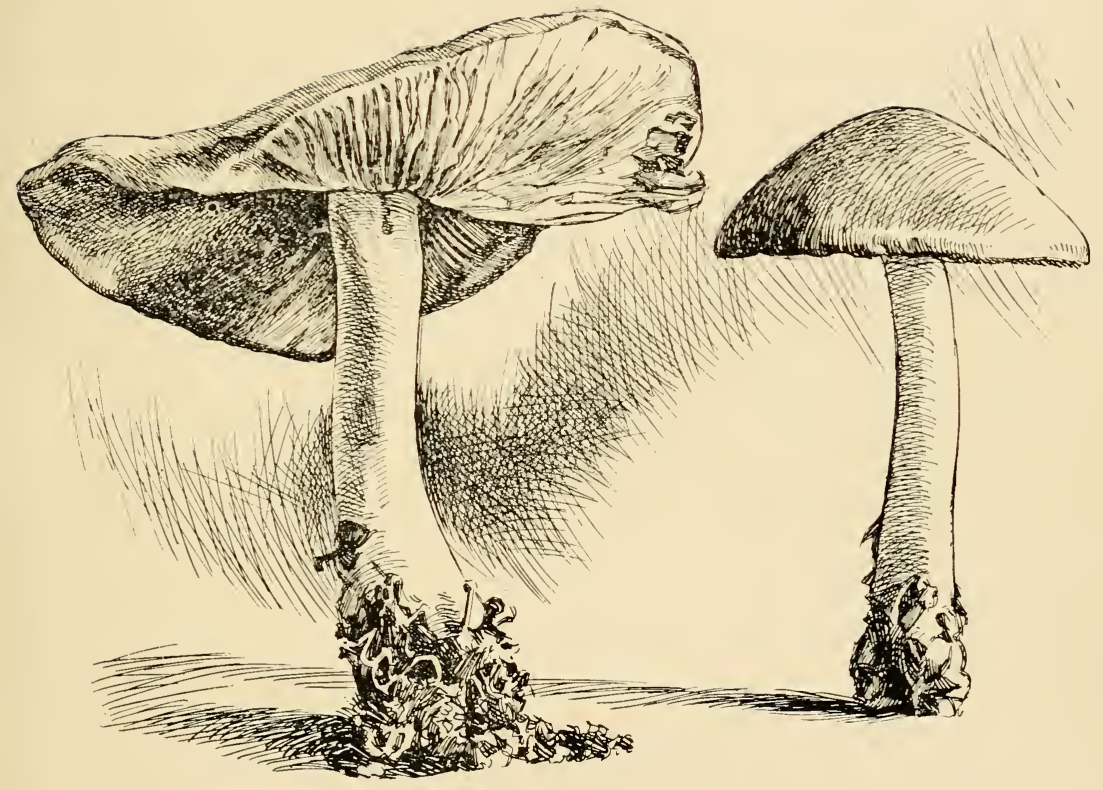

ENTOL,OMA RHODOPOL,IUS. 

E. rhodopolius. Fr. Rose-grey Entoloma.

Pileus, two to five inches broad, watery, fuscous when young, becoming pale, expanded, somewhat umbonate, margin undulate.

Gills, sinuate, becoming free.

Stem, hollow, white, fibrous, last red with spores.

Minesite woods.

\section{E. sinuata. Fr. Sinuate Entoloma.}

Pileus, five to six inches broad, becoming yellow, white, convex, expanded, lastly repand.

Gills, very broad, sinuate, crowded.

Stem, shining white, compact.

Minesite woods.

E. cuspidata. Pk. The Peaked Entoloma.

Pileus, conical, smooth, having a peak at the apex, margin irregular, yellow.

Gills, broad, ascending, broad at the margin of pileus, sinuate.

Stem, hollow, yellowish.

Jungle.

\section{Genus XiII. CIITOPILUS. Fr.}

Rosy-spored or salmon-color spores.

Stem fleshy, diffused upwards into the pileus, margin at first involute. Hymenophore continuous with the stem. Gills equally attenuated behind, decurrent, not sinuate. Growing on the ground; often strong smelling; pileus more or less depressed or umbilicate, with a similarly colored umbilicus.

Clitopilus corresponds with Clitocybe. 


\section{C. prunulus. Scop.}

Pileus, two to four inches broad, white, fleshy, compact, convex, flat and depressed in center, dry.

Gills, decurrent, white, then flesh color.

Stem, firm, solid, villous at the base.

The plum Agaric, so called from the white bloom covering the plant. It is at no season very common in our county, but met in open woods.

Pure white all over except the decurrent gills, which are of beautiful flesh color. The odor is that of new meal fresh from the mill.

There is a small variety, growing in lawns and roadsides, about the size of 25-cent piece, called the orcella.

Specimen found in Spring Creek woods, near Trexlertown.

\section{C. abortivus. B. and C.}

Perfect, imperfect, or altogether abortive.

Perfect form: Pileus, fleshy, convex, then expanded and more or less irregular, gray or lilac in color.

Stem, solid, nearly equal or somewhat deformed, concolorous.

Gills, arcuate and long decurrent in some specimens, in others nearly plane and adnate-decurrent, at first grayish, at length bright flesh color. Spores angular.

The imperfect and abortive forms present all stages of imperfection to a complete obliteration of all semblance of stipe and pileus when the fungus consists of a rounded, more or less lobed, mass.-Morgan's Mycologic Flora of the Miami Valley, Ohio.

The abortive clitopilus is so called from the many imperfect and abortive plants. The imperfect and abortive forms present all stages of development so as to puzzle the mycologist. The perfect is a beautiful fawn color. The abortive form generally grows near the perfect, sometimes surrounding the base of the stem, which makes it appear like so many puff balls or Lycoperdons.

Locality, Yoder's open woods and jungle, 


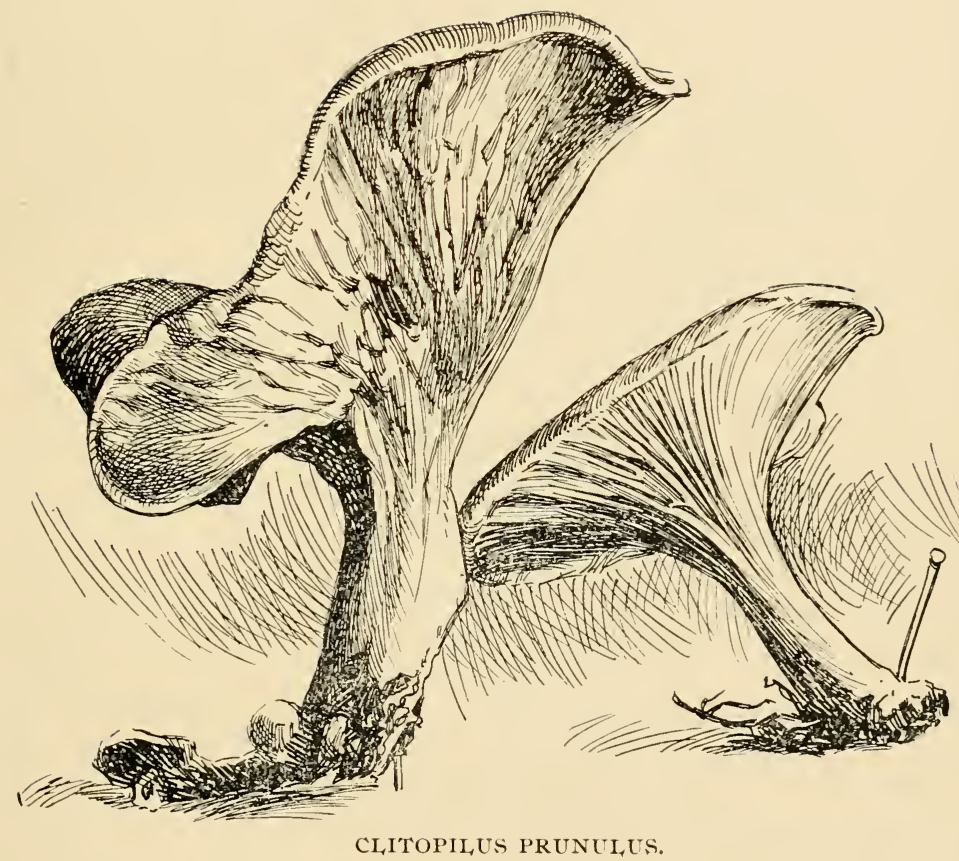

CLITOPILUS PRUNUL, 



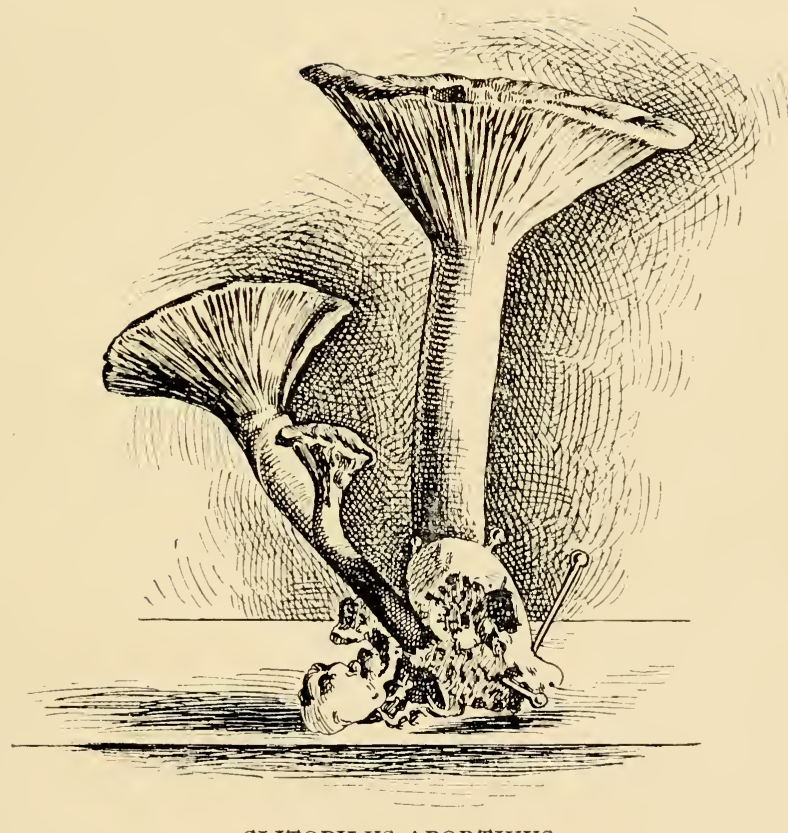

CLITOPILUS ABORTIVUS. 

GEnus XIV. LEPTONIA. Fr. Slender.

Rosy-spored, stem cartilaginous, tubular, polished. Pileus thin, umbilicate or with a darker disk. Margin at first incurved. Gills adnate, but readily separating.

\section{L. serrulata. Pers. Saw Leptonia.}

Pileus, dark blue, flesh thin, umbilicate, depressed, without striæ, squamulose.

Gills, adnate, with a dark serrulate edge.

Stem, thin, cartilaginous, paler than the pileus.

Jungle.

Genus XV. NOLANEA. Fr. A Little Bell.

Rosy-spored, stem fistulous. Pileus thin, campanulate, papillate, margin straight, pressed close to the stem. Gills free, not decurrent.

N. conica. Pk. Cone Nolanea.

Pileus, thin, membranaceous, conical, with a minute umbo or papilla, cinnamon color, striatulate when moist.

Gills, light flesh color, nearly free.

Stem, slender, straight, hollow.

Jungle.

\section{SERIES III. DERMINI. Fr.}

Skin or Membrane.

On account of the cuticle of the pileus being the principal generic character. It is the Ochrospora, Sacc.

Spores, reddish brown, brown, or ochraceous. There are no species with hymenophore free from the stem. 
The following genera have species growing in the Lehigh Valley :

Pholiota-with gills adnate and stem annulate.

Inocybe-with gills more or less sinuate and a scaly pileus. Hebeloma-with gills more or less sinuate and a smooth pileus.

Flammula-gills sharply adnate or decurrent.

Naucoria-stipe cartilaginous, gills adnate.

Galera-pileus campanulate, stipe cartilaginous.

\section{GENUS XVI. PHOLIOTA.}

Partial veil in the form of a ring, analogous to Armillaria in the white-spored series. They grow mostly on dead trunks of trees. Spores ferruginous or fuscous-ferruginous.

Stem confluent and homogeneous, with the hymenophore furnished with an annulus.

\section{P. precox. Pers. Early Pholiota.}

Pileus, fleshy, convex, obtuse, margin even, pale buff, watery near the gills, which is a character; when dry it assumes a dirty white color.

Gills, adnate, slightly sinuate, moderately broad, not ventricose; edge lighter than the other part, which gradually becomes brownish.

Stem, solid, which becomes hollow with age, juicy, white. Ring, near the top of stem, deflexed.

Spores, oval, .0003 $\times .0003$.

The early Pholiota is one of our first fleshy fungi in early Spring. In favorable weather it makes its appearance about the middle of May. Grain fields and grassy lawns are full of them. Never met with them in our woods. 
The name is derived from precox-early.

The species seems to be cosmopolitan, since it is recorded in nearly all the records on fungi, viz: Persoon, of France; Fries, of Sweden; Berkley, Cook, etc., England ; Lenz and Ebighaus, of Germany.

\section{P. durus. Hard Pholiota.}

Pileus, more compact than the Precox. Convex, then plane, cuticle cracked, margin even, color like the Precox, only paler.

Gills, adnate, with a tooth, ventricose, livid, then brown rust color.

Stem, hard, thickened upwards and mealy.

Ring, torn, more or less evanescent.

Not as common as the Precox. In manured gardens. June.

P. adiposa. Fr. Pineapple Pholiota.

Pileus, fleshy, convex, obtuse, very glutinous; the scales are darker than the surface, which is of a ripe pineapple color.

Gills, broad, rounded behind, adnate, with a tooth, ferruginous, edge white.

Stem, equal, curved, some slightly thickened at the base, brown below, yellow above.

Ring, is generally attached to the margin of the pileus, scarcely forming a ring.

The fat pholiota, so named from the thick and heary pileus, is a beautiful yellow color, with darker spots, viscid when moist; grows out of rotten spots on apple trees, or any other tree which has a favorable nidus. The albocrenulatus of Peck is almost similar. Specimens were found on a rotten spot on an apple tree in 'Trexlertown.

\section{P. spectabilis. Fr. The Showy Pholiota.}

Pileus, compact, convex, then plane, cuticle torn into silky scales, which disappear towards the margin, fleshy; flesh pale yellow. 
Gills, adnexed, rounded near the stem, tawny.

Stem, four inches high, one inch or more thick; solid, tough, and spongy, thickened towards the base, even bulbous.

Ring, rather thick near the apex.

This beautiful species is scarce, for I only met with it in a few localities. Koch's island, near Trexlertown. Grows on rotten oak stumps.

\section{P. squarrosoides. $\mathrm{Pk}$.}

Pileus, firm, convex, viscid when moist, at first densely covered by erect papillose or subspinose tawny scales, which soon separate from each other, revealing the whitish color and viscid character of the pileus.

Gills, close, emarginate, at first whitish, then pallid or dull cinnamon color.

Stem, equal, firm, stuffed, rough, with thick squarrose scales, white above the thick floccose annulus, pallid or tawny below.

Spores, minute, elliptical, .0002 inch long, .00015 inch broad.

Densely cæspitose, three to six inches high, pileus two to four inches broad, stem three to five lines thick.

Named from the dense squarrose scales covering the pileus and stipe. It is a late customer; does not appear until late in the season. Grows in tufts inside of rotten stumps and logs It is viscid when moist, shining when dry. Not edible.

Squarrosoides means like squarrosus, because it is almost similar to the squarrosus, Muell., of Europe.

\section{P. squarrosus. Müll. Scaly Pholiota.}

Pileus, fleshy, campanulate, expanded, covered with squarrose scales, tawny yellow.

Gills, yellowish, changing to brown, adnate or rounded near the stem. 


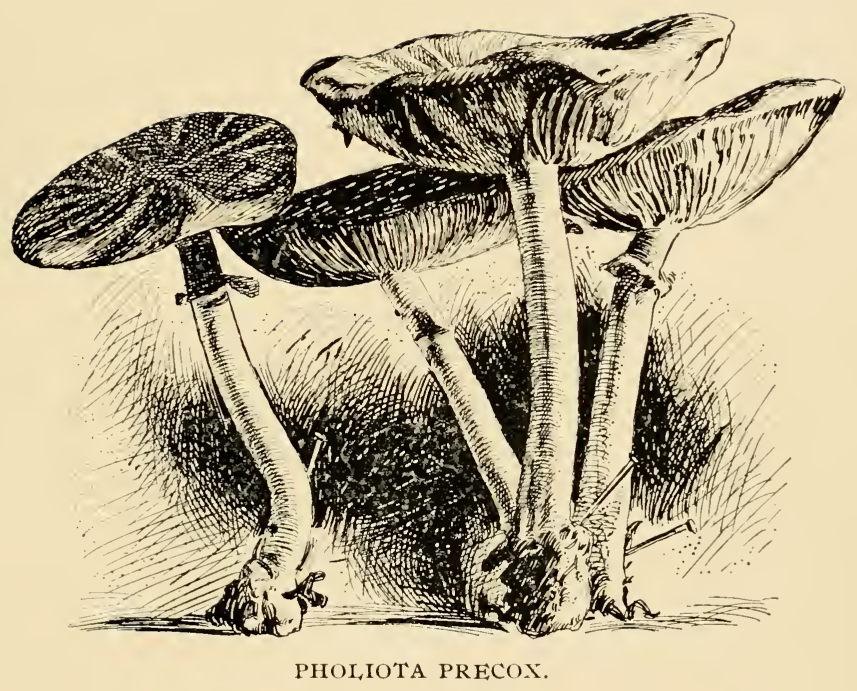



Stem, three to six inches high, fibrillose, squarrose, with reflexed scales, saffron yellow.

Ring, membraneous, rather heavy, with a slimy coat.

Frequent on rotten logs late in fall.

\section{P. marginatus.}

Pileus, fleshy, convex, smooth, hygrophanous, brown, becoming pale, first around the margin, then the whole of the pileus; margin thin, striated.

Gills, adnate, crowded, watery, cinnamon colored.

Stem, fistulous, soft, not scaly, pruinose above the fugacious ring.

The marginate Pholiota grows abundantly on damp, rotten logs; it is one of our visitors, and lasts till late in fall. Common in the damp thickets.

\section{P. æruginosa. $\mathrm{Pk}$.}

Pileus, convex, glabrous greenish, spotted with brown, slightly rinosa-areolate, flesh pale-green, one-half to two inches.

Gills, broad, rounded behind, adnate, ochraceous when young, becoming bright ferruginous.

Stem, solid, fribrillose, sulphur yellow.

Spores, copious, bright ferruginous.

Found on a railroad tie on the Catasauqua \& Fogelsville railroad, near Trexlertown. Named by Prof. Peck.

\section{P. curvipes. Fr.}

Dead trunks of young trees. August. Our specimens have the lamellæe floccose-crenate on the edge.-Peck's Reports.

The crooked-stem Pholiota is found growing on old logs late in autumn. The description of the typical species has the crooked stipe not as long. It generally prefers hemlock lumber to grow on, but is found to take hold of even the hardest timber. 
Genus XVII. INOCYBE. Fr. Sys. Myc. Fibrehead.

Universal veil fibrillose, concrete with the cuticle of the pileus, often free at the margin in form of a cortina. Gills somewhat sinuate, sometimes adnate. Spores fuscous-feruginous, corresponds with Tricholoma. It is readily distinguished by the silky fibrillose covering of the pileus, which never has a distinct pellicle by the veil. All grow on the ground.

\section{I. hirsutus.}

Pileus, one-half inch high when campanulate, one inch when expanded, fuscous, squarrose with pilose scales, margin fringed.

Gills, adnexed, pallid, then fuscous, slightly toothed.

Stem, solid, slender, fibrillose, scaly at the apex, dark-green at the base.

Trexlertown cemetery.

I. scaber. Rough Inocybe.

Pileus, convex, fleshy, obtusely gibbous, scaly, margin entire, grayish-brown.

Gills, rounded near the stem, close.

Stem, solid, equal, fibrillose, veiled.

Common in damp woods. Grows on the ground.

\section{1acerus. Fr. Torn Inocybe.}

Pileus, convex, expanded, obtuse, umbonate, squamose, fibrillose, dry.

Gills, adnexed, rentricose, tinged with flesh-color, then cinereous.

Stem, slender, short, rufescent, one-half to one inch long.

This species grows under trees, where there is not much grass, on bare, clayey soil. Abundant in groups. June to November. Throughout our Valley. 
I. pyriodorus. Pk. Pear-scented Inocybe.

Pileus, conical, obtuse, margin revolute, at last fribrosquamulose, fleshy, flesh whitish.

Gills, sinuate, dirty white, then light clay.

Stem, stuffed, firm, fibrillose, mealy, and pale above.

In open woods, on rich ground. Where this species wants rich soil the lacerus wants poor soil. Spring Creek woods, near the Lehigh creek.

I. geophyllus. Sow. The Earth Inocybe.

Pileus, strongly conical, expanded, umbonate, white, silky, flbrillose, dry.

Gills, adnexed, white at first, then earth-colored.

Stem, one to two inches high, subbulbosus, firm, mealy above.

On the ground in open woods. Common throughout the Lehigh Valley.

\section{GENUS XVIII. HEBELOMA.}

Partial veil, fibrillose clothed. Stem somewhat mealy at the apex. Margin of pileus incurved. Gills sinuate, adnate, edge more or less of a different color, whitish. Cuticle of pileus continuous, smooth, viscid. Spores clay-colored. Growing on the ground. Corresponds with Tricholoma in the white-spored group.

\section{H. glutinosa. Linn.}

Pileus, one to three inches, yellow-white, disk darker, convex, plane, viscous gluten, in wet weather flesh white, becoming yellow.

Gills, sinuate, afirate, somewhat decurrent, pallid, light yellow, clay color.

Stem, stuffed, somewhat bulbous.

Partial veil in form of a cortina. Yoder's open woods, Late. 


\section{H. longicauda. Pers.}

Pileus, one and a half to two inches broad, clay color, the disk sometimes becoming fuscous, fleshy, not compact, convex then expanded, umbonate, at length repand, even smooth, viscid; flesh soft, watery, but not hygrophanous.

Stem, four inches long, three to four lines thick, hollow, fragile, equal or thickened at the base, absolutely fibrillose, white, mealy at the apex, at length becoming tawny at the base. No cortina manifest.

Gills, arcuato-adnate, crowded, six lines broad, white clay, at length cinnamon, serrulated and somewhat dotted at the edge.

Odor weak, not unpleasant, in no wise that of the radish.Stevenson's British Fungi.

This specimen was found in an open woods near Albright's mill, in a marshy jungle. It does not quite agree with Sowerby's specimen. It did not quite fill the characters given by him for geophyllus. Caespitose. It was growing in rings almost like marasmius oreades.

\section{H. firmus. Pers.}

Pileus, two to three inches broad, brick-red, fleshy, campanulate then flattened, umbonate, the broad umbo darker, thin at the circumference, even smooth, viscid.

Gills, rounded, crowded, two to three lines broad, thin, arid, clay-color then ferruginous, unspotted, but white serrulated at the edge.

Stem, two to three inches long, one-half inch thick, solid, firm, somewhat attenuated and commonly darker downwards, clothed throughout with white floccose squamules. Cortina evident, white.

The gills do not distil drops, hence they are unspotted. Odor weak.-Stevenson's British Fungi. 
The stout Hebeloma. At first I took this to be a variety of the fastibilis of Fries, but on further investigation I came to the conclusion that it was a firmus.

It grows in clusters on claybanks along the roadside. It is an interesting species. The stipe is beautifully checkered with suow-white squamules. The odor is faint, not unlike a radisl.

Specimen found on a bank on the road leading from Dorneysville to Allentown, near the limekiln at the woods, September, I893.

\section{H. fastibilis.}

Pileus, convex, expanded, repand on one side, obtuse, smooth, margin involute, woolly, ochraceous, with a rusty tinge, sometimes with a dull reddish hue, fleshy.

Gills, broad, with drops of water on the edge, ventricose, emarginate, white at first, then ochraceous, edge serviate.

Stem, subbulbous, or nearly equal, somewhat rooting, clothed with white scattered somewhat squarrose scales, upper ones forming almost an annulus. Solid when young then hollow, frequently crooked at the base. Odor weak, radishlike or bitter.

Dorney's woods, October.

H. versipellis. Changeable Hebeloma.

Pileus, fleshy, convex plane, viscid, with a tenacious gluten, smooth, brown.

Gills, rounded, whitish, flesh-color, then clay-color with spores.

Stem, fibrillose, brownish internal, dirty white external.

Under an oak tree, near Trexlertown.

\section{GenUS XIX. FLAMMUI,A. Fr.}

Spores ferruginous, approaching yellow ochre, always bright in color; veil filamentous, often obsolete ; pileus fleshy ; either dry, squamulose, viscose, smooth, and silky. 


\section{F. Highlandensis. $\mathrm{Pk}$.}

Pileus, fleshy, thin, convex, becoming nearly plane, glabrous, viscose, yellowish red, paler on the inflexed margin, flesh white.

Gills, close, adnate, decurrent, with a tooth, pale, or yellowish when young, beconing ferruginous.

Stem, equal, stuffed, or hollow, fibrillose and minutely floccose, squamulose, yellow, spores elliptical .00024 to .0003 inch long, .00o 6 broad.

Found in a lawn near a burned or charred stump, and determined by Prof. Peck.

\section{F. rigida. $\mathrm{Pk}$.}

Pileus, thin, rather firm and rigid, convex, plane, glabrous, hygrophanous, rusty tawny when moist, buff or pale tan when dry.

Gills, adnate, white, rusty, with spores.

Stem, rigid, slightly striated with a tomentose base-one to one and a half inches broad.

Grows on chips. Found specimens in one locality from October to April. It ought to be named frigida instead of rigida, for it can bear any amount of cold.

\section{F. flavida. Pers.}

Pileus, fleshy, broadly convex, or nearly plane, glabrous, moist, pale yellow; flesh white or yellowish, taste bitter.

Gills, adnate, yellowish, becoming ferruginous.

Stem, equal, more or less curved, hollow, fibrillose, whitish or pale yellow, with a white mycelium at base.

Pileus one to two inches broad.

Found on decaying logs in open woods. Minesite woods. July and August.

F. sapinea. Fr. Bright-colored Flammula.

Pileus, convex, plane, finely flocco-squamulose. 
Gills, adnate, broad, golden yellow.

Stem, stuffed, sulcate, yellow, without a ring.

Pine boards. Lumber yards.

F. anomala. $\mathrm{Pk}$.

Pileus, umbilicate, irregular, smooth, whitish.

Gills, decurrent, pale, ferruginous.

Stem, short, irregular, whitish.

Spores, brown, ferruginous.

Koch Island. First discovered, September, 1994.

\section{F. rhodoxanthus.}

Pileus, fleshy, obconic, slightly tomentose when young, areolated when older, brown, with a yellow tinge, flesh yellow.

Gills, deeply decurrent, not very close, bright yellow.

Stem, even, solid, sometimes curved, slightly punctated.

This species is Berkley's Paxillus flavidus, named from a dried specimen, which did not have the characters of a Paxillus, that is, the easily separating gills from the hymenophore, and the anastomosing of gills near the stem. Scbweinitz named it Gomphidius rhodoxanthus, but it is no good Gomphidius, for it has not the typical gluten covering the plant. Flammula is the best pigeonhole for it; hope it will stay there. C. G. Lloyd first put me in mind to change it to the genus Flammula.

Genus XX. NAUCORIA. Naucum, a nut.

Species of this family are small with a cartilaginous stipe. Gills adnate, sometimes nearly free. Growing on wood on ground. Spores different shades of brown, veil absent, or attached to the edge of the pileus, stem cartilaginous, confluent with but heterogeneous from the hymenophore. 


\section{N. semiorbicularis.}

Pileus, fleshy, hemispherical, then expanded, even, smooth, viscid.

Gills, adnate, broad, crowded, pallid then ferruginous.

Stem, slender, tough, straight, pallid, ferruginous, shining, with a separable pith.

This is one of our most common toadstools in the Lehigh Valley, growing in their season in almost any location, grass lawns, roadsides, edges of woods, but very seldom in dense woods.

\section{N. pediades. Fr.}

Pileus, one to two inches broad, yellow or pale yellowish ochraceous then becoming pale, obtuse, even, dry, smooth, at length rimoso-rivulose, but always without striæ; flesh white.

Stem, two to three inches long, one to two lines thick, stuffed with a pith, somewhat flexuous, tough, equal, but with a small bulb at the base, slightly silky becoming even yellowish.

Gills, adnexed, two lines broad, at first crowded, at length somewhat distant, somewhat fuscous then dingy cinnamon.

Spores, fuscous ferruginous. The small bulb at the base is formed by the mycelium being rolled together. Stature variable.-Stevenson's British Fungi.

From its growing in fields, especially in grain fields. It grows in conjunction with the semiorbicularis.

Common in our fields during June and July.

\section{Genus XXI. GALERA.}

Spores ochraceo-ferruginous, veil often wanting. Pileus more or less campanulate, margin straight, at first depressed to the stem, stem cartilaginous, confluent with and heterogeneous from the hymenophore. 


\section{G. tener.}

Pileus, submembranaceous, conica-campantilate, obtuse, watery.

Stem, straight, fragile, rather shining.

Gills, crowded, adnate, broad.

Common in lawns.

\section{G. Hypnorum. Batsch.}

Pileus, membranaceous, conic, cinnamon, striated, watery when moist, pale when dry.

Gills, ascending, cinnamon color, whitish at the edge.

Stipe, cinnamon color.

Very little difference in character to the above, only smaller, and always found on a bed of moss. Common in our woods.

Genus XXII. CLAUDIPUS. Fr. Lame Foot.

Pileus excentric, lateral or resupinate-that is, without a stem. Spores rubiginous. A small group intermediate between Hyporhodii and Dermini.

\section{C. variabilis. Pers.}

Pileus, white, thin, resupinate; that is, gills turned towards the light, tomentose, even, being fastened in the center to a short villous stem.

Gills, at first white, then the color of the spores.

On rotten sticks. In nearly every open woods in the Valley.

\section{SERIES IV. PRATELII OT MELANOSPORAE.}

From pratum, a meadow.

Spores, purple brown or dark brown. There are four genera under this group. 
Psalliota is not used any more as a subgenus; since the other subgenera are elevated to the rank of genera, the genus Agaricus being retained in its stead.

The following genera are included under the Pratelli.

Genus XXIII. AGARICUS. Linn. Sys. Nat. 1735.

Spores dark brown-purple, dead brown, pale slate. Veil universal, concrete with the cuticle of the pileus and fixed to the stem, forming a ring. Gills free, rounded behind, at first white, then pink, and lastly purple brown. There are two species found growing in the I,ehigh Valley.

A. campestris. Linn. Common mushroom.

Pileus, fleshy, convex plane, dry, silky, floccose-squamulose.

Gills, free, ventricose, flesh-colored, then brown to almost black.

Stem, stuffed, even, white.

Ring, thick, spongy, medial.

This species is sometimes called campester in place of campestris. It is the common mushroom which from the most ancient times has been used for food; out of it the numerous varieties have been cultivated. Campestris and A. rufescens are the only Agaricini that allow of being cultivated. The young and undeveloped plants, called the buttons, are mostly relished. The spores and gills are dark purple when ripe and finally black. The gills are at first pink. The top of pileus dirty white with darker scales. Some years it is rather abundant in fields and copses.

This is the Pratiola of the Italians. "May he die of a pratiola," is the worst wish of an Italian for his enemy. It is curious that this innoxious fungi of England and America should be poisonous in Italy, but no doubt it is owing to the climate.

Fig. I represents a full plant. Fig. 2 represents a section of a young plant and a developed plant. 


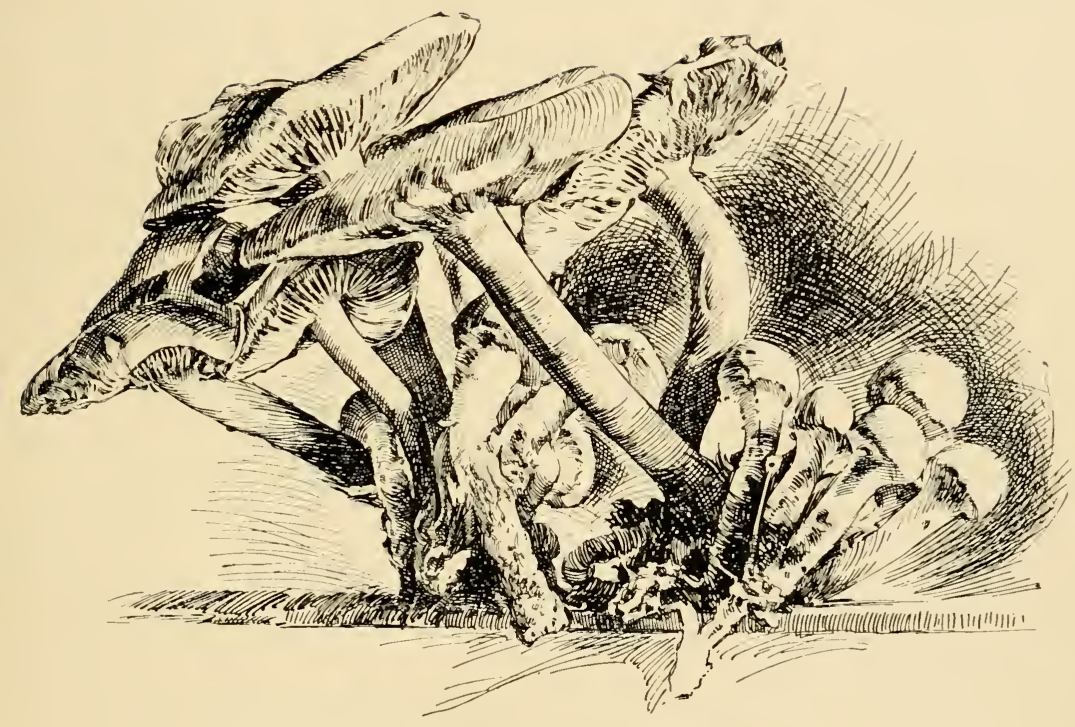

HYPHOLOMA PERPLEXIM. 

A. sylvaticus. Schaeff. Wood Agaricus.

Pileus, flesh thin, campanulate, then expanded, gibbous, fibrous.

Gills, free, crowded, dry, reddish, then brown purple.

Stem, hollow, white.

Ring, distant, thin.

Scarce in the Valley. Found specimens in Spring Creek woods, and near Allentown.

GenUs XXIV. STROPHARIUS. Fr.

Strophos, a sword-belt.

Hymenophore continuous with the stem. Veil annular. Gills adnate. Corresponds with Armillaria of the white-spored series.

S. squamosus. Fr.

Pileus, three inches broad, squamose, ochraceous, convex, flattened, viscid when moist.

Gills, adnate, crowded, cinereous, then dark fuscous.

Stem, tubular, hollow, ferruginous below.

Scarce. Haus's Hill and in woods near Catasauqua.

\section{S. semiglobatus. Batsch.}

Pileus, from one-fourth to one-half inch broad, yellowish, hemispherical, obtuse, viscous.

Gil1s, adnate, clouded with black.

Stem, fistulose, straight, yel'owish, glutinous veil with an incomplete ring.

Spring Creek woods.

\section{GFi US XXV. HYPHOLOMA.}

Veil woven into a web around the margin. Gills emarginate, spores dark purple. Hymenophore continuous with the 
stem. Veil woven into a web, which adheres to the margin of the pileus. Pileus fleshy, margin at first incurved. Gills adnate or sinuate. Hypholoma correspond with Tricholoma, Entoloma, and Hebeloma.

\section{H. perplexum. $\mathrm{Pk}$.}

Pileus, convex, fleshy, expanded, light, brown with a pale yellow margin, disk reddish.

Gills, rounded, sinuate, easily separating from the stipe, pale yellow, greenish cinereous, finally purple brown.

Stem, subequal, firm, fibrillose, hollow, yellow reddish at the base, light brown.

The $\mathrm{H}$. fascicularis and sublateritius are almost similar species, with very little difference, and are nearly related species.

This is called the troublesome agaric or toadstool owing to its nearly related character to the European $\mathrm{H}$. fascicularis. During the autumn nearly every stump is surrounded by clusters of it, and even as late as December you can find fully developed plants. It is easily recognized by its olive greenish gills and brownish yellow top. The young plant has a spider-web veil. It is no doubt poisonous. I have seell no record of its properties, and I am slow in testing its qualities.

Common on oak stumps throughout the Lehigh Valley late in fall.

\section{H. orne11a. $\mathrm{Pk}$.}

Pileus, convex, pale yellow, with darker scales, with a thin veil attached to margin; margin thick entire.

Gills, emarginate, yellowish at first, then dark purple from the spores.

Stem, crooked, smooth, solid.

Scarce in chaparral woods. Near Cedar Creek.

\section{H. appendiculatus. Bull.}

Pileus, thin ovate, expanded, watery, when dry covered 
with dry atoms, margin thin and often split, with a white veil hanging; the color when moist is dark brown, when dry nearly white.

Gills, adnate, crowded, white, then rosy brown.

Stem, fistulose, equal, white, fibrous, mealy at the apex.

The veiled hypholoma is common in our lawns and yards. It is of a dull white on top of pileus, very brittle, flesh thin, gills white at first, then violet and lastly dark with the dark purple spores. The stem is white and hollow. It is not poisonous. In young specimens the veil hangs from the margin of the pileus; hence the name.

\section{H. candolleanus. Fr.}

Pielus, thin, or somewhat fleshy, conical, expanded, watery, color same as the $\mathrm{H}$. appendiculatus.

Gills, rounded behind, crowded, purple or violet, then brown cinnamon.

Stem, hollow, straight, subfibrillose.

This is almost similar to the preceding, excepting the gills are purple from the first. It is named after De Candolle, the great French botanist.

Common in rich lawns.

Genus XXVI. PSILOCYBE. Persoon. Naked Head.

No veil. Stem cartilaginous, rigid, tubular. Pileus more or less fleshy, smooth, the margin more or less incurved.

Psilocybe corresponds to Collybia, Leptonia, and Naucoria. All grow on the ground.

\section{P. fœnisecii. Persoon.}

Pileus, pale fuscous or brownish, convex, campanulate at first, dry, smooth.

Gills, adnate, ventricose, fuscous, then umber.

Stem, fistulous, straight, white, pulverulent, then fuscous.

Common in grassy lawns, in profusion after summer showers. June and July. 


\section{SERIES V. COPRINARII.}

Spores black, hence the gills, which are all separate from each other, never become purple or fuscous. The genus Coprinus is readily distinguished by the gills cohering at first (not separate) and by their becoming fluid, etc. Intermediate between Agaricus and Coprinus.

\section{Genus XXVII. PAN AEOLUS.}

Veil all woven, often wanting. Pileus fleshy or membraneous without striæ. Margin exceeding the gills. Gills ascending to top of cone.

\section{P. separatus. Linn. Distinct, alone.}

Pileus, one inch high, cylindrical, whitish, obtuse, viscous, smooth.

Gills, adnate, separating, ascending, black.

Stem, long, tense, straight, attenuated from the thickened base, whitish, smooth.

Ring, distant, entire.

Common in open woods. Very partial to a heap of horse manure, deposited in open woods.

\section{P. campanulatus. Linn. Bell.}

Pileus, one inch high, and broad, fuscous, slightly fleshy, campanulate, convex, dry, shining.

Gills, ascending, crowded, varying grey and black.

Stem, fistulous, tense, straight, veil, fugacious.

The bell-shaped Panæolus grows in rich ground near a dung heap. The stipe is thin and long. Belongs to the black-spored family without the gills deliquescing, or Coprinarii. Not edible.

P. papilionaceus. Fr.

Pileus, slightly fleshy, hemispherical, rimoso-scaly when dry. 


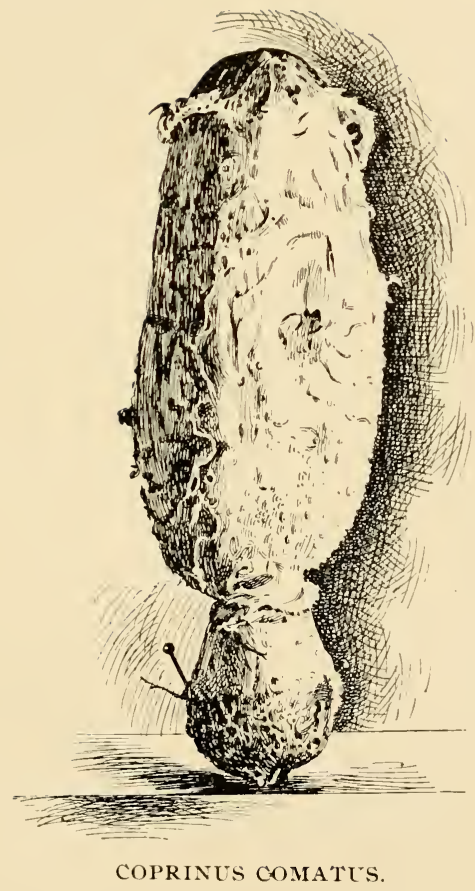



Gills, broad, adnate, very broad, varying tiuts of black. Stem, equal, whitish, white pulverulent at apex.

Common in grassy lawns.

\section{P. fimicola. Fr.}

Pileus, campanulate, convex, obtuse, smooth, marked near the margin with a narrow brown zone.

Gills, adnate, variegated with brown and greyish.

Stem, pale, fragile.

This is the dung agaric, growing only on dung. Common during the summer.

\section{GenUS XXVIII. PSATHYRELLA.}

Pileus membraneous, small and fragile, striated, margin not exceeding the gills. Gills dark but not deliquescing.

\section{P. disseminatus. Pers.}

Pileus, ovate, campanulate, furfuraceous, sulcate, striated, ochraceous at first, then white.

Gills, pinkish, adnate, cinereous, black when old.

Stem, tender, white, fistulose, pubescent at the base.

The scattered psathyrellus is a tiny little toadstool growing around trees and stumps. It grows in clusters two to three feet in extent; very delicate. They seem to melt away as soon as picked.

In lawns near or surrounding stumps of trees.

\section{Genus XXIX. COPRINUS. Persoon.}

Hymenophore confluent with or free from the stem. Gills membranaceous, at first closely pressed together and cohering, at length melting away into a black fluid. Spores 
oval, black. Called ink mushroom. An easily recognized genus. The biological difference of gills, as compared with the preceding genera, is very remarkable, in deliquescing to an inky fluid.

C. comatus. Fr. From coma, hair. Shaggy maned.

Pileus, cylindrical, white, shaggy, with hair-like scales, the darker disk remaining adherent. Margin striated.

Gills, free, ascending, broad, white, or pinkish at first, then deliquescent into a black fluid.

Stem, hollow, with spider-web fibres within, radiate, bulbous when young, lilac white.

The shaggy-maned mushroom is the type of the family. It is a very handsome plant, and easily identified by its beautiful cylindrical form and pure white color. It never expands fully, only as far as campanulate. The margin of gills are at first a beautiful pink, but finally deliquesce into an inky fluid. Edible, delicious, and tender.

Dr. Henry B. Bashore writes to the Medical Record as follows: "Its nutritive value is high, for it contains 25 per cent. of protoids," and calls it a valuable addition to our food supply.

Not as common as some of our smaller coprini, such as atramentarius, micaceus, Fir., etc.

\section{C. atramentarius. Fr.}

Pileus, fuliginous or smoky, slightly frosty, ovate, obtuse, deeply sulcate, soft to the touch, expanded.

Gills, ascending, free, ventricose at first, cohering, whitish, inky black.

Stem, ventricose, fusiform, tapering upward, rudiment of a ring at the base.

This species is named from the gills dissolving into an inky fluid (from atramentum, ink). This is one of the most common of our Corprini. It is easily identified by the peculiar base of the stem, which has a beveled ring where it enters the ground, dirty-white with darker scales. The flesh is thin, the pileus is nearly all gills. Gills at first light, then gradually becoming black. Edible. 
C. micaceus. Fr. Mica.

Pileus, yellow, ferruginous, at length date brown; flesh thin, margin lobed, striated, covered with mica-like scales.

Gills, adnexed, broad, deliquescent.

Stem, hollow and soft, fibrillose, whitish, with specimens with a strigose base.

Named from the glittering scales covering the young gills and pilens. It generally grows in clusters in grassy lawns and on rotten stumps, has a preference for willow stumps. It is an interesting specimen from its peculiar manner of growth. The scales are like so many beads made of diamonds. It sometimes grows in such thick clusters as to deform the center specimen. It grows all summer, from early spring until late in fall, and is recorded in every country where a record is had of fungi.

Edible ; suitable for catsup.

\section{C. tomentosus. Fr.}

Pileus, membranaceuus, cylindrical, conical, striated, floccotomentose, longitudinal cracked.

Gills, free, brownish black.

Stem, hollow, velvety, equal.

This is a beautiful Coprinus found in a cave cellar in our village. I was in doubt at first about the identity of the species. The affinities corresponded to those described by Fries as flocculosus, but after comparing character, it agreed sufficiently to place it with tomentosus.

The beautiful tomentose scales rub off easily and are not persistent.

In a cave cellar on the Weaver's hotel property, Trexlertown, Pa.

\section{C. ephemerus. Fr.}

Pileus, very thin, oval, subfurfuraceous, disk elevated, even.

Gills, adnexed, distant, whitish, brown, then black, melting. Stem, pellucid, smooth.

This is named from its transient existence, lasting only a few lours. It may spring up in the early morning and as soon as the rays of the sun touch it, it deliquesces into an inky fluid. When fully developed it is a nice specimen, beautifully striated from margin to center. Grows in well-manured grass plots. 


\section{Lloydii. N. Sp.}

Pileus, very thin, ovate at first, then campanulate, expanded, sulcate plicate.

Gills, light at first, at length dark.

Stem, fistulous, tender.

C. G. Lloyd discovered this new species south of Trexlertown, Pa., I898. It comes near C. ephemerus, but with characters sufficiently different to make it a good species.

\section{Genus XXX. CORTINARIUS.}

This genus received the name from cortina, a spider-web veil, which is the principal character of the genus. It requires a young specimen for its detection, for the veil is very delicate. Parts of it are thickened, which are attached to the margin of pileus and stem. The hymenophore and the gills are continuous with the stem. Gills persistent, dry, changing color, last pulverulent, with rusty spores, which drop slowly. Trama fibrillose. Spores rusty or clay color. Growing on the ground.

The veil and gills are the principal marks of distinction. They are very different in appearance in the different stages of growths, moist or dry. It is necessary to examine them in the different stages.

The genus is divided into six tribes or subgenera, which might be elevated to the rank of genus, the same as the subgenera of the genus Agaricus. They are :

TRIBE I. Phlegmacium or Schleimkopf, which has the pileus viscous, stem dry, veil spider-web.

TRIBE 2. Myxàcium (mucus). Whole plant is viscous, pileus and stem. The stem is thickly coated with gluten, but only when it is wet or moist; when dry it is glossy. The Germans call it the Schleimfuss pilze. 
TRIBE 3. Inoloma (a fibrous fringe). Pileus fleshy, dry, silky with scales fibrous, flesh not watery. Veil simple, stem dry and fleshy, somewhat bulbous. Germans call it Dickfuss.

Tribe 4. Dermocybe (Skinhead, Ger. Hautkopf). Pileus thin and equally fleshy, at first silky with a villous down, getting smooth when older, not watery. Stem equal, elastic, sometimes hollow. Veil single, fibrillose. Gills generally of a bright color.

Tribe 5. Telamonia (lint). (Ger. Guertelfuss.) Pileus moist, watery at first, smooth or sprinkled with whitish fibres, flesh thin or becoming so abruptly at the margin. Stem annulate below, from the universal veil or peronate with scales, somewhat corticate at the apex, with a partial veil.

Tribe 6. Hygrocybe (Moisthead, Ger. Wasserkopf). Pileus smooth or only covered with white fibrils, not viscous, but moist when fresh, changing color when dry, flesh thin, rarely more compact at the disk. Stem rigid, not sheathed. Veil thin, fibrillose. Gills thin.

\section{TRIBE I. Phlegmacium.}

Pelicle of pileus viscid when moist or wet. Veil dry, simple, that is, a spider-web veil from the stem to margin of pileus.

This tribe is divided into three subtribes. Two have the stem thickened at the base and the third has an even, elastic stem.

\section{C. (Phlegmacium) porphyropus. Fr.}

Pileus, thin, flattened, first lead color, later brownish, flesh turning to light purple when cut.

Gills, sinuate, adnexed, light purple, then cinnamon color, with spores. 
Stem, light brown, turns to a light purple or lilac on being bruised, solid.

This plant was found in a thicket south of Trexlertown.

\section{C. (Phlegmacium) caperatus. Fr.}

Pileus, fleshy, ovate, expanded, obtuse, moíst, incrusted with superficial white flocci, yellowish.

Gi1ls, fixed, serrate, crowded, clay colored.

Stem, stout, even, white, squamulose at the apex from the stout, membraneous ring.

From capero, to wrinkle, from the wrinkled condition of the pileus. This is placed by some authors under Pholiota, but Fries had the priority for Cortinarius. The pileus is of a pale yellow and rugose, spotted with film like white spots.

This beautiful Cortinarius is quite common in its season, in oak groves, growing singly on the ground.

\section{C. (Phlegmacium) communis. Pk.}

Pileus, fleshy, convex, whitish or gray, disk deeper color.

Gills, broad, emarginate, white, then ochraceous cinnamon. Stem, straight, sometimes inclined, even, white.

This is a very common species in our Lehigh County woods. Some of the species grow to a large size, while others are ordinary, depending on the soil favorable for development. It belongs to the tribe Phlegmacium, Schleimkopf of the Germans.

Found near Trexlertown. August.

\section{C. (Phlegmacium) selaginellus. N. Sp.}

Pileus, viscid, orbicular, fleshy, flesh turning purple when cut ; epidermis brownish purple, covered with soil, margin deflexed, never expanded, except the outside specimens.

Gills, purple from the first, broad, sinuate, rusty at last, from the spores.

Stem, curt, emarginate, bulbous, purplish, solid, veiled with the remainder of the purple spider-web veil. 
This is rather a small species, pileus never more than two inches broad; stem never more than an inch high. They grow caspitose, from ten to fifteen in a cluster, the center ones much deformed from side pressure.

Found on Koch's Island, late in fall, along the banks of a stagnant water pond, covered with selaginella, hence the proposed name.

\section{C. (Phlegmacium) 1uteofuscus. Pk.}

Pileus, fleshy, broadly convex, even, smooth, brown.

Gills, rather close, yellow, then cinnamon, deeply emarginate.

Stem, equal, nearly straight, solid, silky, striate, whitish, bulbous.

Height about four inches, breadth of pileus two inches, stem three to four lines thick.-Peck's Reports.

Luteofuscus ( $f u s c u s$, or light brown of pileus, yellow gills). This species is not common. I only found a few specimens. Belongs to the series scauri, a subtribe of Phlegmacium.

C. (Phlegmacium) purpurascens. Fr.

Pileus, four to five inches broad, bay brown, viscid, spotted when old, often depressed around the margin, which is at first inflexed then repand, flesh wholly azure blue.

Stem, solid, thick, marginate, bulbous, blue, darker when touched.

Gi1ls, emarginate, crowded, blue at first then cinnamon, violaceous blue when bruised.

In open woods throughout Pennsylvania.

\section{C. (Phlegmacium) subpurpurascens. Fr.}

Pileus, tawny-fuliginous, becoming pale, not compact, obtuse, at length very much dilated and undulato-flexuous, viscous, obsoletely streaked with fibrils, somewhat spotted; flesh soft, whitish (verv faint azure blue), unchangeable. 
Gi1ls, sometimes emarginate, almost free, sometimes decurrent, pallid, then cinnamon, becoming purple when bruised.

Stem, 7.5-10 cent. (3-4 in.) long, I $2 \mathrm{~mm}$. ( $1 / 2$ in.) thick, at length hollow, somewhat cylindrical, marginato-bulbous at the base, fibrillose below, naked above, smooth, slightly striate, pale azure-blue or whitish.-Stevenson's British Fungi.

Common in open woods.

C. (Phlegmacium) glaucopus. Fr.

Pileus, compact, expanded, viscid, floccose squamose, flesh yellowish.

Gills, emarginate, blue then pale, then rusty.

Stem, solid, thick, bulbous, which disappears, pale blue.

The pale blue stemmed Cortinarius. The flesh is also pale blue. It belongs to the subtribe Scaurii, or clubfoot. Chaparral ridgewood.

C. (Phlegmacium) cærulescens. Fr.

Pileus, convex, expanded, even, viscid; flesh soft, azure blue; flesh firm, not changing color when bruised.

Gills, adnate; distant, subdecurrent, violet, at length rusty, with spores.

Stem, bulbous, solid, flbrillose from veil.

This is one of the most robust of the family. The pileus is brownish convex. The base of stipe turbanate bulbous. The veil is pale blue. The gills intensely blue.

Laros's schoolhouse.

TRIBE II. Myxacium. Ger. Schleimfuss.

Slimy-stem Cortinarius. Pileus and stem glutinous, polished when dry.

C. (Myxacium) collinitus. Fr.

Pileus, convex, expanded, obtuse, glutinous, purplish when young, later brownish. 
Gills, adnate, clay colored, then cinnamon.

Stem, straight, besmeared with a glutinous veil.

Common in Kuhn's woods, near Chapman's Station on the Catasanqua \& Fogelsville Railroad.

\section{C. (Myxacium) stillatitius. Fr.}

Pileus, thin, convex, subumbonate, even, viscid, yellow.

Gi11s, emarginate, distant, ferruginous.

Stem, hollow, soft, attenuated, covered with a blue gluten.

Bastian's woods, near Wescoesville.

\section{TRIBE III. Inoloma.}

Pileus equally fleshy, dry, at first silky, with innate scales or fibrils, flesh continuous, not hygrophanous. Veil single. Stem, fleshy, somewhat bulbous. Species very distinct. There are Telamoniæ which resemble Inolomata, but they differ from them by having the pileus smooth, moist, then torn (whereas the Inolomata hecome smooth), or by being sprinkled over with white superficial fibrils, and by possessing a double veil.Stevenson's British Fungi.

\section{C. (Inoloma) violaceus. Linn.}

Pileus, fleshy, obtuse, villoso-squamulose, of a deep violet color.

Gills, broad, thick, distant, of a deep violet, becoming rusty. Stem, bulbous, spongy, villous, internally cinereous violet.

This is an old described species. It was named by Linneus over one hundred years ago. It is a beautiful species. The whole plant is of a light blue or violet color. Not very abundant, grows single in open woods.

Bastian's woods. It is recorded in all works on fungi. 


\section{C. (Inoloma) alboviolaceus.}

Pileus, fleshy, rather thin, convex, then expanded, sometimes broadly subumbonate, smooth, silky, whitish, tinged with lilac or pale violet.

Gills, generally serrulate, whitish-violet, then cinnamon color.

Stem, equal or a little tapering upward, solid, silky, white, stained with violet, especially at the top, slightly bulbous, the bulb gradually tapering into the stem.

Height, three to four inches, breadth of pileus two to three inches, stem three to six lines thick.-Peck's Reports.

The whole plant is of a light violet hue. You will often meet with it during the Cortinarii season. It springs up not only in dry and arid localities, but also in wet and swampy places.

\section{C. (Inoloma) autumnalis. $\mathrm{Pk}$.}

Pileus, fleshy, convex or expanded, dull rusty yellow, varigated or streaked with innate ferruginous fibrils.

Gills, rather broad, with a wide, shallow emargination.

Stem, equal, solid, firm, bulbous, a little paler than the pileus.

Height three to four inches, breadth of pileus two to four inches, stem six lines thick.-Peck's Reports.

This is an American species, named by Prof. Peck autumnalis on account of its occurring late in the season. I have found it nevertheless early in September in a wet jungle. It is very deceiving on account of the gills remaining pallid so long.

\section{C. (Inoloma) iodes. B. \& C.}

Pileus, convex, dry, fleshy, bright violet, spotted with alutaceus spots, which is a good character.

Gills, adnate, violet from the first, becoming rusty.

Stem, bulbous, violet, solid, streaked with fibres of the veil.

Common in open woods. It is one of the earliest of the family. 
C. (Inoloma) pulchrifolius. $\mathrm{Pk}$.

Pileus, convex, expanded, silky fibrillos, whitish or reddish gray, the margin often white by the veil.

Gills, emarginate, distant, bright purple, and last rusty from the spores.

Stem, solid, bulbous, fibrillose, white, often tinged with violet, violet within.

Found specimens on Koch's Island. Not common in the Valley.

\section{Tribe IV. Dermocybe.}

Pileus thinly and equally fleshy, at first silky with somewhat innate villous down, but becoming smooth when old, dry and not hygrophanous. Flesh watery when moist or colored. Stem equal or attenuated, externally more rigid, elastic or brittle, internally stuffed or hollow. Veil single, fibrillose, forming a zone in C. caninus. A natural group easily distinguished from Inolomata by the thinness and substance of the pileus and by the stem; and from the following tribes by the pileus not being moist or hygrophanous, and by its short floccose or atomate covering, its brighter color.

The species of this tribe are very changeable, and not easily defined on account of the changeable color of the gills. It comprehends two primary types ; first of $\mathrm{C}$. anomalus with the flesh of the pileus white, and secondly that of C. cinna-. momeus with the flesb scissle and colored.-Stevenson's British Fungi.

\section{C. (Dermocybe) cinnamomeus. Fr.}

Pileus, thin, obtuse, umbonate, cinnamon brown, silky with innate yellowish fibres.

Gills, adnate, cinnamon brown.

Stem, hollow, thin, equal, veiled. 
Named from the color of pileus, which is a cinnamon yellow, belongs to the tribe of Dermocybe, Hautkopf of the Germans. The pileus is thin in the flesh. Common in Minesite woods.

\section{C. (Dermocybe) sanguineus. Fr.}

Pileus, rather thin, convex or expanded, with decurved margin, silky or minutely squamulose, bright red.

Gills, rather close and broad, emarginate, a little darker red than the pileus.

Stem, equal, stuffed or solid, nearly smooth, concolorous.

Height about two inches, breadth of pileus six to twelve lines, stem one to two lines.-Peck's Reports.

Prof. Peck determined this species as merely a variety of the $C$. cinnamomeus.

Found in chaparral ridgewood, the only locality in the Lehigh Valley.

\section{Tribe V. Telamonia.}

Pileus moist, hygrophanous, at the first smooth or sprinkled with superficial whitish fibres of the veil. Flesh thin throughout or becoming so abruptly at the margin (not equally attenuated), scissile. Stem annulate below from the universal veil or peronate with scales, somewhat cortinate at the apex, hence the veil is somewhat double. To this tribe are referred some species, intermediate between this and the preceding one, on account of their double veil, the universal one forming a slight ring, and their pileus not being silky.-Stevenson's British Fungi.

\section{C. (Telamonia) distans. $\mathrm{Pk}$.}

Pileus, thin except the disk, convex, squamulose, baybrown when moist, tawny when dry.

Gills, broad, distant, thick, dark cinnamon color.

Stem, subequal, often a little tapering upward, solid, slightly fibrillose-scaly, concolorous. 
Height two to three inches, breadth of pileus one to two inches, stem four to six lines thick.-Peck's Report.

This is one of our earliest Cortinarii. Fuund in a dense underbrush south of Trexlertown.

TRIBE VI. Hygrocybe. Wasserkopf.

Pileus thin, campanulate, convex, even, color of chestnuts.

\section{C. (Hygrocybe) castaneus. Fr.}

Chestnut Cortinarius.

Pileus, thin, campanulate, convex, even, color of chestnuts.

Gills, crowded, ventricose, violet, brown when older.

Stem, cartilaginous, hollow, even, smooth, violaceus, white, with reil.

Common in moist places.

\section{GENUS XXXI. HYGROPHORUS.}

The hymenium waxy or watery. This genus is known by the watery condition of the gills. The species are not numerous in our county. The eburneus, erubescens, and coccineus are the more common.

H. pratensis. Fr.

Field or Meadow Hygrophorus.

Pileus, one to two inches broad, pale yellowish, compactly fleshy, with an umbo, thin towards the margin, convex, almost turbinate, from the stem being expanded upwards, even, smooth, moist, flesh firm, white.

Gi11s, deeply decurrent, arcuate, distant, thick, separating from the stem.

Stem, stuffed, attenuated downwards, whitish.

Common in pastures after a rainy spell. 


\section{H. conicus. Fr.}

Pileus, fragile, flesh thin, conical, carmine when young, smooth, viscid.

Gills, free, ventricose, yellowish, waxy.

Stem, hollow, fibrillose, striated.

This is an interesting species, and easily identified by its turning black. This is generally the first Hygrophorus to appear in spring, and crops appear all summer.

Abundant in Albright's woods, near Trexlertown.

H. eburneus. Fr. Shining White.

Pileus, fleșhy, compact, convex, plane, even, glutinous, margin soon naked.

Gills, decurrent, distant, veined at the base, entire.

Stem, stuffed, then hollow, glutinous like the pileus, rough at the apex, with dots in the form of scales.

Common late in the fall. Open woods in Pennsylvania.

\section{H. erubescens. Reddish.}

Pileus, two to four inches broad, whitish, becoming red, viscid, adpressed with squamules or becoming smooth, compact, flesh white.

Gills, white, decurrent, soft, with red spots.

Stem, short, robust, equal or attenuate at the base, solid, with red fibrils, dotted with red upwards.

Common late in fall all through the Valley.

\section{H. coccineus. Fr.}

Pileus, fragile, thin, convex, obtuse, viscid, scarlet, growing pale yellow.

Gi11s, adnate, with a decurrent tooth, connected by veins, yellow.

Stem, hollow, flattened, smooth, yellow.

This species is of bright scarlet color at first, but soon turns to a light yellow. Very fragile. Cosmopolitan. 
H. virgineus. Fr.

Pileus, fleshy, convex, obtuse, flat on top, moist, satin white.

Gi11s, decurrent, waxy, distant, venose connected.

Stem, stuffed, attenuated towards the base, white, dilated upwards.

Common in cemeteries and grassy fields.

\section{H. chlorophanus.}

Pileus, thin, convex, margin striated, yellow.

Gills, adnexed, waxy, ventricose, distant, whitish.

Stem, viscid when moist, yellow whitish.

Scarce in the Valley.

\section{GenUs XXXII. GOMPHIDIUS.}

Hymenophore decurrent on the stem. Gills composed of a mucilaginous membrane, scissile, continuous at the acute edge, pruinate with the blackish fusiform spores. Veil viscosofloccose. Growing on the ground, fleshy, putrescent, pileus at length turbinate; gills decurrent, distant, soft. A small genus, with great differences among the species, intermediate by its habit between Cortinarius and Hygrophorus.-Stevenson's British Fungi.

\section{G. vinicolor. $\mathrm{Pk}$.}

Pileus, thick, convex, and nearly plane, viscid, dark red, becoming black on drying.

Gi1ls, distant, decurrent, olive brown or blackish when mature.

Stem, subequal, smooth, solid, vinous color, paler within. 
Spores, fusiform, .0007 to .0008 inch long and .00024 to .0003 inch broad.

Pileus one and one-half to two inches broad.

Trexlertown cemetery, under a white pine tree, the only locality in the Lehigh Valley.

\section{Genus XXXIII. PAXILIUS.}

Hymenophore continuous with the stem, decurrent. Gills membranaceous, scissile, somewhat branched and here and there anastomosing behind, distinct from the hymenophore and readily separating from it. Spores dingy whitish or ferruginous. Fleshy, putresent, pileus at first with the margin involute then continuously and gradually unfolded and dilated, indeterminate.-Stevenson's British Fungi.

\section{P. involutus. Fr.}

Pileus, compact, convex, plane, then depressed, moist, becoming plane, margin involute and tomentose, brown, becoming darker.

Gills, branched and anastomosing behind, near the stem, easily separating from the hymenophore.

Stem, fleshy, solid, firm, thickened upwards, brown, spotted.

This genus is named from Paxillus, small stake. This specimen was found along the side of a mossy bank on the mountain near Macungie.

P. atrotomentosus. Fr. Dark Downy Paxillus.

Pileus, fleshy, convex, plane, then depressed or infundibuliform, granulose, margin thin, involute.

Gills, crowded, straight, branched behind, brownish.

Stem, solid, elastic, curved, ascending, clad with a dense black velvet covering.

Scarce in the Lehigh Valley. 


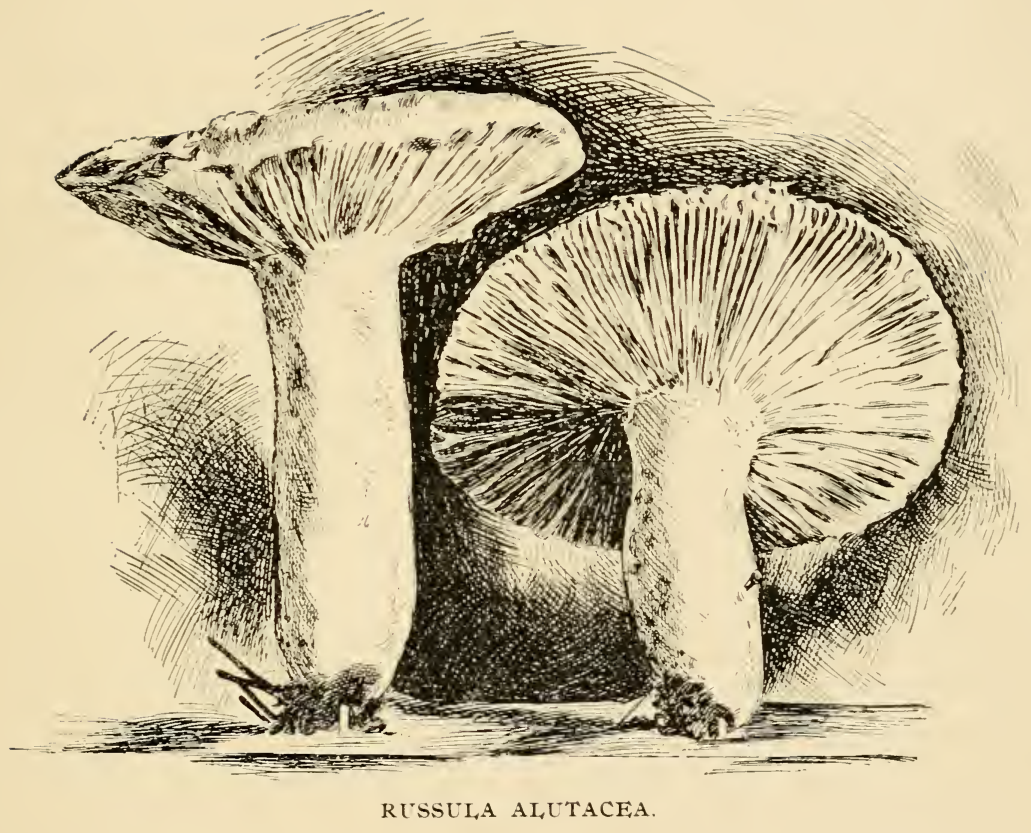





\section{Genus XXXIV. RUSSULA.}

From russulus, reddish.

This genus is one of easy recognition; but the individual species are quite different, on account of the similarity of color and stature, which it is often difficult to properly identify. It is an interesting genus, because it contains specimens with beautiful coloring.

The genus contains some of the best edible fungi, while some are very poisonous, so as to require good judgment and a knowledge of the characters between the good and bad. The best and safest method is first to be sure you have a Russula, which is easy, then break a piece off the stem and taste it. If it is acrid, that is, a burning sensation on your tongue, discard it at once, for all poisonous Russula are acrid and all nonpoisonous ones have a mild taste.

The Pennsylvania flora of Russula is quite numerous. No open grassy woods is without some specimeus. Russula is related to Lactarius in figure and stature, but lack the milky juice.

There are two species peculiar to Pennsylvania recorded in no other State-R. subdepallens, Pk., and a beautiful variety of $\mathrm{R}$. fœtens, var. rubescentipies, Pk. The family has some of the most palatable species, such as the virescens, alutacea, integra, etc.

For the purpose of more easily identifying species, the genus is divided into different groups. Masse divided the genus into two groups, the acrid and the mild, or the poisonous and the edible.

Fries made five groups, viz:

Compactæ, with a compact texture and brittle.

Furcatæ, with a compact texture and tough.

Rigida, pileus dry, without stria.

Heterophyllæ, from a typical species. 
Fragiles, texture soft and brittle, margin striated, with a viscid pellicle.

R. nigricans. Bull. Dark Russula.

Pileus, two to four inches broad, dark fuscous, at length nearly black, fleshy, flesh turning red when cut or bruised, convex, flattened, umbilicato, depressed, margin entire.

Gills, rounded behind, slightly adnexed, thick, distant, reddening when touched.

Stem, solid, equal, pallid when young, at length black.

Taste disagreeable, not edible. Easily identified by the black color.

Common in August and September throughout the Valley. Very abundant in Dorney's woods near Allentown, Pa.

\section{R. adustus. Pers. Smoky Russula.}

Pileus, fuliginous, cinereous, flesh compact, margin even and inflexed; center depressed.

Gills, adnate, decurrent, thin, crowded, unequal, white, not reddening when bruised.

Stem, solid, obese, of the same color as the pileus.

In appearance it is similar to R. nigricans, but differs from it in not having the red color on being bruised.

Common in Dorney's woods near Allentown.

\section{R. delica. Fr. Weaned Russula.}

Pileus, three to four inches or more broad, fleshy throughout, firm, umbilicate, regular, margin entire, smooth, white, flesh firm, juiceless.

Gills, decurrent, distant, unequal, white, exuding drops of water in wet weather.

Stem, solid, thick, short, white.

In appearance it is like unto Lactarius vellereus.

Common in open woods all through the Valley. July and August. 
R. sordida. $\mathrm{Pk}$.

Pileus, three to five inches broad, firm, convex, then depressed in center, dry, sordid white.

Gills, close, white, some few forked.

Stem, thick, equal, solid, concolor, when wounded becoming at first rusty, then bluish black.

Common in open woods throughout the Valley. It has a disgusting odor in drying.

\section{R. furcata. Pers.}

Pileus, greenish, entire, fleshy, compact, margin even, convex, plane depressed, margin thin, at first inflexed, pellicle separable in spots.

Gills, adnate, decurrent, rather thick, attenuated at both ends, frequently forked, shining white.

Stem, solid, white, attenuated downwards.

Taste bitter, considered poisonous. May easily be mistaken for $\mathrm{R}$. virescens (which are edible) owing to the green color; but the gills are decurrent and the pellicle of the pileus is even, not arcolated like in $\mathrm{R}$. virescens.

In open woods. Frequent. July and August.

\section{R. depallens. Pers.}

Pileus, pale red, inclining to darker red, fleshy, firm, generally irregular shaped and undulated, even, the thin adnate pellicle changing color, the spreading margin even, slightly striated when older, flesh white.

Gills, adnexed, forked at base, often with shorter ones mixed, white.

Stem, solid, attenuated downwards, white, becoming cinereous when older.

Common in woods. July and August. 


\section{R. subdepallens. $\mathrm{Pk}$.}

Pileus, fleshy, convex, then expanded or centrally depressed, nnargin entire at first, then tuberculate striated, blood red, or purplish red, mottled with yellowish spots, becoming paler, or almost white with age, often irregular, fleshy, fragile, white, becoming cinereus with age, taste mild.

Gilis, broad, subdistant, adnate, white, the interspaces venose.

Stem, stout, solid, spongy.

Spores, white, globose, rough, size .0003 inch broad.

Closely related to $\mathrm{R}$. depallens, from which it differs in having the margin striated, and pileus being spotted at first, the gills more distant.

This species was discovered by myself some years ago, near Trexlertown, under a hickory tree. It has returned every season from June to November. Peck's new species, copied from Torrey Botanical Club, ISg6.

\section{R. 1actea. Fr. Milky Russula.}

Pileus, convex, campanulate, often excentric, dry, without a viscid pellicle, cracked when old, margin straight, even, obtuse, milk white at first, then $\tan$ white, throughout compactly fleshy, flesh white.

Gills, free, very broad, thick, distant, forked white.

Stem, solid, compact at first, then spongy, always pure white.

Chaparral wood.

R. virescens. Fr. The Green Russula.

Pileus, orbicular, from three to four inches broad, innate flocculose. The prominent color is greenish, with a faint tinge of yellow towards the margin; umbilicate when full grown; margin not always entire, as the European description gives it. But more frequently slightly striated. 
Gills, pure white, free from the stipe, nnequal.

Stem, white, spongy, thick, erect.

This a common Russula in the Lehigh Valley woods in the proper and favorable seasons. Taste mild and nutty ; so much so that squirrels are very fond of them. You can often meet with specimens where they were gnawe by those little hungry animals, interfering largely with gathering specimens. These animals are good testers to tell the difference between the acrid and poisonous and the mild species of Russula.

R. lepida. Fr. Neat Russula.

Pileus, blood red, becoming pale whitish on the disk, convex, expanded, scarcely depressed, margin even, obtuse, dry.

Gills, rounded behind, rather thick, crowded, connected by veins, often red at the edge.

Stem, thick, even, white or rose color.

This is one of our handsomest species of the group. Common in all open woods in the Valley.

\section{R. rubra. Fr. Red Russula.}

Pileus, unicolor, cinnabar red, becoming pale when old, dry, without a movable pellicle, compact, convex, then flattened, here and there depressed, often rivuloso-rimose, margin obtuse, even, flesh white, reddish under the cuticle.

Gills, adnate, crowded, whitish, then yellowish.

Stem, solid, even varying white and red.

Very acrid; poisonous. Not very common; now and then you will meet with scattered specimens.

\section{R. flavida. Pk. Yellow Russula.}

Pileus, broad, fleshy, convex, yellow, becoming pale with age, flesh white, margin even, then tuberculate striate.

Gills, white, simple, broad in front, adnately interveined.

Stem, yellow, smooth, thick, short, equal, tapering upwards, solid.

Taste mild. In grassy open woods. Chaparral woods. 
R. heterophylla. Fr. Unequal-gilled Russula.

Pileus, variable in color, but never reddish or purple, fleshy, firm, convex plane, with a thin pellicle, which disappears, margin thin, even, or slightly striated.

Gills, reaching the stem in an attenuated form, very narrow, crowded, forked and dimidiate, white.

Stem, firm, solid, even, shining white.

Taste mild. In woods, especially on clayey slopes. Lehigh Valley. Edible ; mild to the taste.

R. cyanoxanthus. Schaff. Bluish Yellow Russula.

Pileus, lilac or purplish, then greenish, disk yellowish, margin blue or purple, convex, then plane, depressed in center, pellicle viscid, margin deflexed, remotely striated, flesh firm.

Gills, rounded behind, connected by veins, forked, white.

Stem, solid, spongy, stuffed, often cavernous, equal, white.

Mild. Common in woods near Cedar Fountain Creek.

\section{R. fœetens.}

Pileus, dirty white or yellowish, flesh thin, bullate, balllike, then expanded, covered with a pellicle which is adnate, viscid in wet weather, margin with ribs, which are at length tuberculate.

Gills, adnexed, connected by veins, with many dimidiate, whitish.

Stem, stout, stuffed, then hollow, concolor.

Acrid, poisonous. Odor fetid, sickening. Not very common in the Valley. Common in chaparral woods.

Var. rubescentipes. $\mathrm{Pk}$.

This is a beautiful variety found in an open woods under oak trees. It is of a beautiful red tint, especially the stem. Prof. Peck determined it and named it as above. 
R. emetica. Fr. Emetic Russula.

Pileus, fleshy, expanded, polished, shining; margin obtuse, at length sulcate; flesh white beneath the reddish viscid cuticle; rose red, yellow red, or even purple.

Gills, free, equal, broad, somewhat distant, white, and remaining white.

Stem, rugulose, firm, solid, white, or tinged with red.

Acrid ; very poisonous. Rare in Lehigh County.

This is a beautiful Russula-" a wolf in sheep's clothing." Of a beautiful red at first on top with a movable pellicle. Gills a pure white and of one length. Stipe pure white.

The whole plant has an innocent appearance, and yet is very poisonous. It has a different physiological modus operandi than the poisonous Amanita. The alkaloid is quicker and is more of a local irritant.

A good account of the properties of this poisonous Russula can be found in Lenz's "Schaemme," 6te Auflage von Dr. O. Wuensche, Gotha.

"Im August, 1760, fuegte es sich, das meine Koechin zu Triest rothe Taeub inge (Russula) nach Hause brachte, welche sie auf Anrathen als gute und schmackhafte Schwaemme gekauft hatte. Sie wurden mit Oel, salz und Pfeffer zubereited. Eine Viertelstunde darauf ueberfiel mich ploetzlich eine grosse Schwaeche und Beschwerlichkeit, Beaengstigung des Magens, die immer staerker wurde; zwang mich vom Tische aufzustehen, am offenen Fenster frische Luft zu Schoepfen und mich durch selbe zu erholen. Bald wurde ich mit einem starken Schwindel eingenommen-bald mit heftigem erbrechen ohne unterlass."

\section{R. fragilis. Fr. Tender Russula.}

Pileus, thin, fragile, plane, depressed, cuticle thin, becoming pale, viscid, margin tuberculate, striate.

Gills, thin, ventricose, white.

Stem, stuffed, hollow, shinning.

Acrid. Poisonous. Abundant in some of our woods. Sometimes it is mistaken for a small R. emetica.

\section{R. integra. Entire Russula.}

Pileus, fleshy, expanded, with a viscid cuticle; growing pale; margin thin, at length sulcate and tuberculate. 
Gills, nearly free, broad, equal, distant, white, then pallid, powdered with the yellow spores.

Stem, spongy, even, ventricose, white.

Taste mild, edible.

This is a very confusing Russula, on account of it assuming so many different colors. I was often deceived with it at first.

\section{R. nitida. Fr. Shining Russula.}

Pileus, somewhat fleshy, becoming rigid, convex plane, margin tuberculate striate; flesh white.

Gills, adnexed, crowded, white, then yellow.

Stem, stuffed, soft, white, growing pallid.

Acrid, nauseous, poisonous.

Common along roadsides throughout the Valley.

\section{R. atropurpurea. $\mathrm{Pk}$.}

Pileus, at first convex, then centrally depressed, glabrous, dark purple, blackish in the center, the margin even or slightly striate, flesh white, grayish or grayish-purple under the separable pellicle, taste mild, odor of the drying plant fetid, very unpleasant.

Gills, nearly equal, subdistant, sometimes forked near the stem, at first white, then yellowish, becoming brownish where bruised.

Stem, equal, glabrous, spongy within, white, brownish where bruised.

Spores, subglobose, minutely rough, pale ochraceous with a salmon tint, .0003 to .0004 inch long.

Pileus three to four inches broad; stem two to three inches long, five to eight lines thick.

Found a number of specimens in Dorney's woods near Allentown. Determined by Prof. C. H. Peck. Mild. 
R. alutacea. Fr. Tan-colored Russula.

Pileus, fleshy, expanded, with a viscid cuticle, growing pale; margin thin, tuberculate-striate; flesh white, pileus flesh color to tan color.

Gills, ventricose, free, connected with veins, equal, yellow, ochraceous.

Stem, blunt, surface longitudinal wrinkled, spongy within, white, sometimes yellow.

Taste mild, edible.

Common in open woods. You can get specimens almost in every woods after a rainy spell. June and July.

\section{R. pectinata. Fr.}

Pileus, convex, fragile, with a viscid pellicle, dirty white or ochraceous, margin spreading, with fine striation or sulcate striate, lastly tuberculous striate.

Gills, equal, light yellow, adnate.

Stem, straight, spongy, then more or less hollow, even, sinooth.

The specific name is from pecten, a comb, from the striæ at the margin being like the tooth of a comb. This species is generally found along the roadside in fence corners. It is not a gay species; the color is a dirty yellow or brownish.

\section{GENUS XXXV. IACTARIUS.}

Hymenophore continuous with the stem. Veil none, except in some species the margin of pileus is bearded. Pileus fleshy, of a vesiculose nature, generally depressed in the center. Margin at first involute. Stem fleshy, often hollow when old, gills milky, in nearly all the species the milk is at first white, changing to sulphur yellow, red or violet on exposure to the air, decurrent, with an acute edge; trama subversiculose. 
Spores white or yellowish, globose or elliptical. The milk agarics are an easily recognized family from the milky juice they contain, their shape and texture. The Russula is the only family that might be mistaken for a milk agaric, but the juice at once proves its place.

The pileus in some species is beautifully zoned, a good mark for a specific distinction. The stem is short and thick, smooth and even. Several species are edible, while others are acrid and more or less poisonous, but I never heard of a case of poisoning from this family. The reason is that the poisonous species are too peppery to be eaten, and yet one of the most acrid is now said to be edible.

L. uvidus. Fr. Moist Lactarius.

Pileus, at first convex, two to three inches broad, fleshy, depressed, somewhat zoned, viscid when wet, pale, rusty, cinereous, with a shade of lilac, speckled with small watery spots.

Gills, paler than pileus, decurrent, the short ones very obtuse, and truncate behind, connected by veins.

Stem, two inches high, one-fourth to one-half inch thick, spongy, at length hollow, strigose at the base, the whole plant white when cut, turning to a beautiful lilac.

Scarce throughout the Valley. Growing in moist localities.

\section{I. scrobiculatus. Fr. Spotted-stem Lactarius.}

Pileus, convex, centrally depressed, viscid when moist, reddish yellow, the margin at first involute, spreading tomentose.

Gills, adnate or slightly decurrent, whitish.

Stem, equal, hollow, adorned by pits of a darker color.

Spores, white, juice white, then yellowish. 
From scrobis, a trench, from the pitted stem. This is a beautiful plant with a yellowish hue. Not very abundant. Found on the Lehigh Mountain near Macungie.

\section{L. piperatus. Fr. Peppery.}

Pileus, compact, convex, umbilicate, then expanded and infundibuliform, even, glabrous, white.

Gills, narrow, close, like a fine-tooth comb, adnate, decurrent, white or cream color.

Stem, white, solid, compact, glabrous, milk white.

This species can be found in its season, almost in any open woods in the Valley. Easily identified by the peppery taste and narrow gills.

\section{I. vellereus.}

Pileus, white, compact, umbilicate or convex, tomentose, zoneless; margin at first inflexed, then reflexed tonientose.

Gills, distant, white, arcuate.

Stem, blunt, solid, pubescent, milk white.

Spores, .00019 x .00034 inch.

From vellus, fleece, on account of the wooly margin.

The color is nearly white. The margin involute at first, then expanded and depressed in the center. Too acrid for esculent purposes. Cosmopolitan.

L. indigo. Schw.

Pileus, convex, plane, depressed in the center, margin straight, flesh blue and compact.

Gills, decurrent, intensely blue, distant.

Stem, solid, curt, tapering downwards, blue when cut, even.

This beautiful species is rare in our Valley. Found it only in Dorney's woods near Allentown, Pa.

L. Gerardii. Pk.

Pileus, fleslıy, flat, dry, buff brown; flesh white, not changing color when cut. 
Gills, decurrent, white, acute, very distinct, interveined, veins conspicuous.

Stem, solid, concolor, with the pileus often crooked, tapering downward.

Common in chaparral woods.

L. atroviride. $\mathrm{Pk}$.

The Dark-green Lactarius.

Pileus, convex, plane depressed in center, with an adherent pellicle, greenish, with darker scales, margin involute.

Gil1s, slightly decurrent, broad, distant.

Stem, short, dark, scaly.

Milk, white.

This species is not common, growing in open woods near Allentown.

\section{L. serifluus. Watery Milk Lactarius.}

Pileus, fleshy, depressed in center, dry, smooth, brown, margin thin.

Gills, crowded, light brown, turning yellowish.

Stem, solid, equal, paler than the pileus.

common in open woods near chaparral. Alvin Bastian's woods.

I. fuliginosus. Fr. Dingy Lactarius.

Pileus, fleshy, soft, depressed, obtuse, dry, zoneless, at first clouded, with a dingy bloom, then naked, cinereous, tan colored, flesh when cut changing to salmon color.

Gills, tan colored, crowded, rather distant.

Stem, spongy, concolor, with pileus.

Milk white at first, then yellowish. Pileus from two to three inches broad.

Common in open woods. Chaparral woods. 
L. volemus. Fr.

Pileus, compact, rigid, plane depressed, obtuse, dry, golden tawny, at length rimoso-rivulose.

Gills, crowded, white, then yellow.

Stem, solid, hard, blunt, pruinose, generally curved like a pear stem.

From volema pira, a kind of a pear, from shape of stem. This is a very common species, of a beautiful rich brown. Milk white. Very abundant and mild. Edible.

\section{L. corrugis. $\mathrm{Pk}$.}

Pileus, convex, plane, expanded, corrugated, dry, bay brown ; margin at first inrolute.

Gills, adnexed, broad, yellowish.

Stem, curt, concolor with the pileus.

The corrugated Lactarius. In appearance it is almost similar to $\mathrm{L}$. volemus but differs by the wrinkled pileus; lighter in color and larger in size.

\section{L. subdulcis. Fr.}

Pileus, thin, papillate, convex, then depressed and polished, even, zoneless, rufous-cinnamon.

Gills, fragile, rufous, crowded adnate.

Stem, stuffed, then hollow, equal, slightly contracted at the apex, pruinose, rufous.

The subsweet lactarius is one of our common fungi. It makes its appearance early in the season and lasts until late in fall. It is not of a large size, of dull brown color, with a contracted stipe at apex. The milk is not abundant. Edible. Cosmopolitan.

\section{I. camphoratus. Fr.}

Pileus, fleshy, rather thin, depressed, dry, lightly zoned in color, smooth, brownish-red.

Gills, crowded, yellowish, red, adnate. 
Stem, stuffed, subundulate, of same color, mild, white.

This has a wrong name, for the odor is not like camphor; more like melilot. Scarce in woods near Allentown.

\section{L. mitissimus. Fr.}

Pileus, small, tawny, one to three inches broad, zoneless, flesh thin, convex, papillate, depressed around the papillæ, even, smooth; flesh pallid, dry.

Gills, adnate, decurrent by the depressed pileus.

Stem, elongated, stuffed then hollow, even, smooth, same color as pileus.

This small Lactarius grows abundantly in open woods, late in fall. I at first took it to be a small L. subdulcis.

\section{GrNus XXXVI. CANTHARELIUS. Adans.}

Hymenophore continuous with the stem, descending unchanged into the trama. Gills thick, fleshy-waxy, fold-like, somewhat branched, obtuse at the edge. Spores white. Fleshy, membranaceous, putrescent fungi, without a veil.

The distinguishing character of the genus consists in the fold-like gills. The Mesopodes commonly grow on the ground; the rest commonly on mosses, very rarely on word. Intermediate between Agaricus and Craterellus. Some are edible, others reckoned poisonous.-Stevenson's British Fungi.

\section{C. cibarius. Fr.}

Pileus, fleshy, flesh white, smooth, at first repand then turbinate or top-shaped.

Gills, thick, distant, of the same color.

Stem, attenuated downwards, smooth, tough, yellow, diffused into the pileus. 


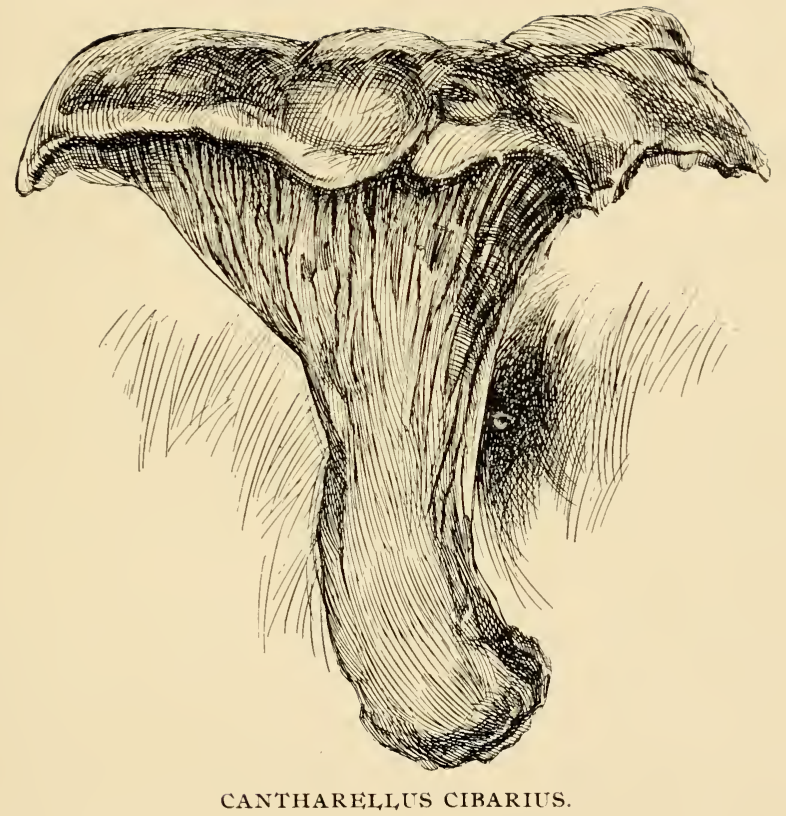



From cibaria, food. Egg yellow, from which the Germans call it Eierpilz. The smell is like that of ripe apricots. It is one of the most delicious dishes.

Cook says of it: "The cantharelle has a most charming and enticing appearance and odor. It is universally eaten in all countries where it is found. In England it is served at the Free Mason Tavern on State occasions." Trattennick says: "Not only this same fungus never did any one harm, but might even restore the dead."

It is common in our woods, growing in groups, during the rainy season of August and September. Cosmopolitan.

\section{C. aurantiacus. Fr.}

Pileus, fleshy, soft, depressed, tomentose, orange color, margin thin, involute.

Gills, dichotomous, crowded, dark orange.

Stem, solid at first, then hollow, crooked, unequal, lighter in color than the pileus.

From aurantiacus, orange yellow. This is often mistaken for the cibarius. The distinguishing mark is the odor and the gills or folds. Also this plant is more slender. This is poisonous and ought to be distinguished. Cosmopolitan.

C. infundibuliformis. Fr. Funnel-shaped Cantharelle.

Pileus, thin, umbilicate, then funnel-shaped, flocco-ochraceous.

Gills, thick, distant, dichotomous, yellowish.

Stem, dilated upwards, thin in the middle, and thickened at the base.

The funnel-shaped cantharelle is not common. Found specimens in woods near Allentown.

\section{C. umbonatus. Fr.}

Pileus, fleshy, thin, umbonate, then depressed, flocculose, dark cinereous.

Gills, straight, crowded, light color.

Stem, stuffed, elastic, villous at the base, cinereous. 
This is Prof. Peck's C. dichotomus in his Twenty-third Report; he was not sitisfied at that time of the identity, but he now considers it the same as Fries's umbonatus on account of the prominent boss on the pileus. The pileus is of a steel blue, the folds of the hymenium are branched, from which character Peck had named it dichotomus.

It lives along mossy banks. The specimens were found in Stephen's woods, near Hartzell schoolhouse.

\section{C. minor. Pk. Small Cantharelle.}

Pileus, fleshy, thin, convex, then expanded, often umbilicate or centrally depressed, glabrous, yellow, flesh pale yellow.

Gills, narrow, distant, sparingly branched, yellow.

Stem, slender, subflexous, subequal, smooth, stuffed or hollow, yellow, with a whitish mycelium at base.

Spores, subelliptical, .00025 to .0003 inch long, .000r 6 to .0002 inch broad.

Plant gregarious or subcæspitose, one to one and one-fifth inches high, pileus six to twelve lines broad, stem one to two lines thick.-Peck's Reports.

Common on clay bank in open woods in the Valley. On Koch's Island and Dorney's woods near Allentown.

\section{Genus XXXVII. NYCTALIS. Fr.}

Veil universal, floccoso-pruinose, subgelatinous.

N. asterophora. Fr. Star-bearing Nyctalis.

Pileus, small, barely a half-inch in diameter, convex, conical, flocco-pruinose.

Gills, often wanting; if present, adnate, distant, white, forked.

Stem, stuffed, pruinose, brownish.

The only specimen of this species was found near Cedlar Creek. Parasitic on Russula nigricans. 


\section{Genus XXXVIII. MARASMIUS. Fr.}

Spores white, subelliptical ; pileus tough, fleshy, or membranaceous; stem central and confluent with the hymenophore, but of a different texture; gills thick, tough, generally distant. Growing on decayed leaves, or root of grapes. This is the first genus of the nonputrescent fleshy Agarics. The principal diagnostic character is the reviving of shrivelled and dry specimens on the application of moisture. They are in form nearly related to the genus Collybia. The Lehigh Valley contains a number of good species.

\section{M. oreades. Fr. Fairy Ring Champignon.}

Pileus, fleshy, umbonate, convex, smooth, alutaceous, pale. Gills, free, broad, distant, cream color.

Stem, solid, equal, naked, with a villous coating, pallid, base naked.

This is not as common as many other species of the fleshy fungi.

The name Fairy Ring is derived from its manner of growing in circles, or part of circles. They seldom form a complete circle in our Lehigh Valley. The first appearance is as early as the beginning of June, when only a few are found. And new ones appear and the old ones revive, until quite a circle is formed again in September. The rings are formed from the excessive growth of the grass, from the fertilizing effect of the decay of the previous year's growth.

M. C. Cooke, in his "British Fungi," says: "That these fairy-rings were the nightly haunts, dancing-grounds, of fairy folks was a general belief before the existence of these little people came to be doubted." One old author writes: "They had always fine music among themselves, and danced in a moonshiny night around or in a ring, as one may see at this day upon every common in England where mushrooms grow."

The Rev. Gerard Smith thus describes the general character of those rings on the grass :

"The nimble elves

Tliat do by moonshine green sour ringlets make, Whereof the ewe bites not; whose pastime 'tis To make these midnight mushrooms." 
Rev. M. J. Berkeley says of the Fairy Ring Champignon: "When of good size, and quickly grown, they are the best of all fungi for the table."

\section{M. semihirtipes. $\mathrm{Pk}$.}

Pileus, thin, tough, nearly plane or depressed, smooth, sometimes striate on the margin, hygrophanous, reddish-brown when moist, alutaceous when dry, the disk sometimes darker.

Gills, subdistant, reaching the stem, slightly venose-connected, subcrenulate on the edge, white.

Stem, equal, even or finely striate, hollow, smooth above, velvety-tomentose toward the base, reddish-brown.

Plant gregarious, inodorous, one to two inches high, pileus six to nine lines broad, stem one-fifth line thick.-Peck's Reports.

Common on nut shells under hickory trees.

\section{1ongipes. $\mathrm{Pk}$.}

Pileus, thin, convex, smooth, finely striate on the margin, tawny red.

Gills, not crowded, attached, white.

Stem, tall, straight, equal, hollow, pruinose-tomentose, radicating, brown or fawn color, white at the top.

Plant two to five inches high, pileus four to six lines broad, stem one-fifth line thick.

Common on leaves in open woods.

\section{M. nigripes. Schw.}

Pileus, membranaceous, campanulate, umbonate, striate, somewhat pellucid, pure white.

Gills, adnate, arcuate, rather broad, pure white, growing pale.

Stem, somewhat bulbous, black, white farinose.-Morgan's Mycologic Flora of the Miami Valley, Ohio.

Common in an underbrush south of Trexlertown, Lehigh County, Pa. 
M. impudicus. Fr.

Pileus, slightly fleshy, tough, convex plane, then depressed; margin at length striate, plicate brownish, growing pale.

Gills, free, ventricose, flesh color, then whitish.

Stem, fistulose, purplish, velvety everywhere, base naked, rooting.

Scarce in the Valley. Odor very offensive.

\section{M. campanulatus.}

Pileus, membranaceous or campanulate, dry, smooth, radiate-sulcate, ochraceous-red, the disk a little darker.

Gills, few, distant, broad, narrowed toward the stem, free or slightly attached, whitish.

Stem, tough, smooth, shining, blackish-brown, hollow.

Height one to two inches, breadth of pileus three to six lines.

Common in open woods and grass plots. Pink form growing in a number of localities in the Lehigh Valley.

\section{M. rotula. Fr.}

Pileus, 6-8 mm. (3-4 lin.) broad, whitish, unicolorous, or with the umbilicus becoming fuscous, arid, membranaceous, slightly convex, umbilicate, plicate, undulato-crenulated at the margin.

Gills, adnate behind to a collar encircling the stem but removed from it, broad, few (often equal), very distant, white.

Common in lawns.

\section{M. saccharinus. Fr.}

Pileus, wholly white, membranaceous, convex, somewhat papillate, smooth, sulcate and plicate.

Gills, broadly adnate, narrow, thick, very distant, reticulato-united, whitish.

Stem, very thin, filiform or attenuated upwards, flocculose, then becoming smooth, inserted obliquely, reddish, pale at the apex.

On dry twigs of oak throughout the Valley. 
GENUS XXXIX. IENTINUS. Fr.

Lentus, tough or pliant.

This genus is characterized by the fleshy and leathery structure, and the edge of gills serrated or torn in a toothed manner. Spores white, orbicular. Nearly all grow on wood. A very natural genus, yet very polymorphic.

I. tigrinus. Tiger-spotted Lentinus.

Pileus, fleshy coriaceous, orbicular, umbilicate, whitish, clothed with innate scales.

Gills, attenuated, narrow, decurrent, toothed, white, then yellowish.

Stem, thin in proportion to the cap, squamulose, with a decided veil.

Not very abundant. Specimens were found on rotten logs at East Penn Junction, near Allentown.

\section{I. lepidius. Fr.}

Pileus, fleshy, compact, convex, then depressed, unequal, broken up into darker scales.

Gills, sinuate, decurrent, broad, torn, transversely striated, whitish.

Stem, stout, tomentose scaly, often crooked.

Common on railroad ties on the Catasauqua \& Fogelsville Railroad.

The pileus is beautifully scaled, ochraceous, brown, irregular, excentric. Stem is tomentose scaly. Some grow to an immense size. Fries mentions a specimen found which was more than two feet in height, growing from a dense leathery stratum which covered yards of wood, from which grew here and there an infundibuliform pileii.

\section{I. umbilicatus. $\mathrm{Pk}$.}

Pileus, umbilicate, dry, tough, bay brown.

Gills, arctuate, broad, strongly serrate, distant.

Stem, even, bent according to the attachment to the wood.

The umbilicate Jentinus is common on rotten oak limbs throughout the Valley. It appears late in fall. 


\section{L. strigosus.}

Pileus, bay brown, strigose, depressed in the center; margin involute, and strongly strigose, tough, leathery.

Gills, decurrent, edge torn, white at first, then brown. Stem, curt, strigose, excentric, concolor.

Not very common; found it on oak stumps throughout the Valley.

\section{Genus XL. PANUS.}

A name given to an arboreal fungus by Pliny. Fleshy and pliant, same as Lentinus, only the edge of gills are entire.

\section{P. strigosus. B. \& C. Hairy Panus.}

Pileus, eight inches broad, excentric, covered with coarse strigose hair, margin thin, white.

Gills, broad, distant, decurrent, straw color.

Stem, stout, two to four inches long, strigose like the pileus.

It is recorded as growing on oak stumps, but I have always found it on decayed spots on apple trees.

\section{P. 1ævis. B. \& C. Light Panus.}

Pileus, three inches, orbicular, depressed, white, covered with a dense mat of hair, margin inflexed and marked by triangular ridges.

Gills, broad, entire, decurrent.

Stem, attentuated upwards, excentric, lateral, solid, strigose beluw, spores white.

Scarce; found specimens on locust trees.

P. salicinus. $\mathrm{Pk}$.

Pileus, one-fourth to one-lialf inch broad, firm, thin, deflexed, hygrophanous, minutely farinaceo-tomentose, pinkish grey. 
Gills, moderately close, converging to an excentric point, dark ferruginous.

Stem, very short or obsolete, obliquely attached to the vertex of pileus.

An interesting specimen growing on willow limbs. When dry and shriveled it will revive on the application of moisture. In a jungle near Trexlertown.

\section{P. stipticus. Fr.}

Pileus, coriaceous, reniform, cinnamon, growing pale; cuticle breaking up into mealy scales.

Gills, determinate, thin, crowded, connected by veins, cinnamon.

Stem, lateral, short.

Common on old logs and stumps all through the Valley. Scarcely one inch broad.

The name stipticus is from the taste, astringent. Poisonous.

\section{GENUS XLI. LENZITES.}

Spores white, pileus coriaceous, dimidiate, sessile. Gills coriaceous, firm, unequal, branched, edge obtuse.

\section{L. betulina. Fr.}

Pileus, corky and coriaceous, firm, zoned, tomentose, pallid, margin of same color as the different shades of the pileus.

Gills, straight, somewhat branched, pallid.

Stem, none.

There is no hard fungi as common on stumps as this one. It is a beautiful sight to see a stump ornamented with it.

\section{L. vialis. $\mathrm{Pk}$.}

Pileus, corky, almost woody, firm, zoned.

Gills, thick, firm, serpentine.

Stem, none.

Common on hemlock timber. 


\section{GENUS XLII. SCHIZOPHYLLUM.}

Pileus fleshless, arid. Gills coriaceous, fan-wise branched, united above by the tomentose pellicle, bifid, split longitudinally at the edge. Spores somewhat round, white.

The two lips of the split edge of the gills are commonly revolute. The farthest removed of all the Agaricini from the type. Growing on wood.-Stevenson's British Fungi.

\section{S. commune. Fr.}

Pileus, adnate behind, somewhat extended, simple, and lobed.

Gills, grey, then brownish purple.

Stem, none, or merely a trace of it.

From communis, common. This deserves well the name, since there is no more common species to be found. Almost on any decayed piece of wood specimens can be found growing. It has a peculiar liking for ailanthus.

Easily known by the gills being double and split by coiling revolute. It can be found all the year round, summer and winter. Cosmopolitan. 


\section{ORDER II. POLYPOREI.}

Hymenium spread on the inside of tubes or pores, which are sometimes broken up into teeth or concentric plates. At first the tubes are merely circular ridges, but finally extend into tubes.

The following genera are included under this natural order, viz:

Boletinus.-Tubes not easily separable from hymenophore, and with a radiating structure.

STROBILOMYCES.-Tubes not easily separable from hymenophore, and without a radiating structure.

BolETUS. - Tubes easily separable from the hymenophore and from each other.

Polyporus. - Trama (tube partition) dissimilar in substance from the hymenophore.

TRAMETES. - Trama similar in substance and color with hymenophore.

D无DALEA. 一 Tubes labyrinthiform, ligneous.

Merulius. - Tubes incomplete, shallow sinuous folds, plant waxy.

Porothelium.-Hymenium papillose and submembranaceous.

No specimens discovered in the Lehigh Valley.

Fistulina.-Hymenium at first papillose, papillæ at length elongated and forming tubes; plant fleshy.

\section{GENUS XIIII. BOLETINUS. Kalch.}

This genus was founded by Kalchbrenner on the characters of Boletus cavipes as a type, viz: Hymenium not even, but extended into the tubes. Tubes not easily separable from the hymenophore and from each other and with a radiating structure. 


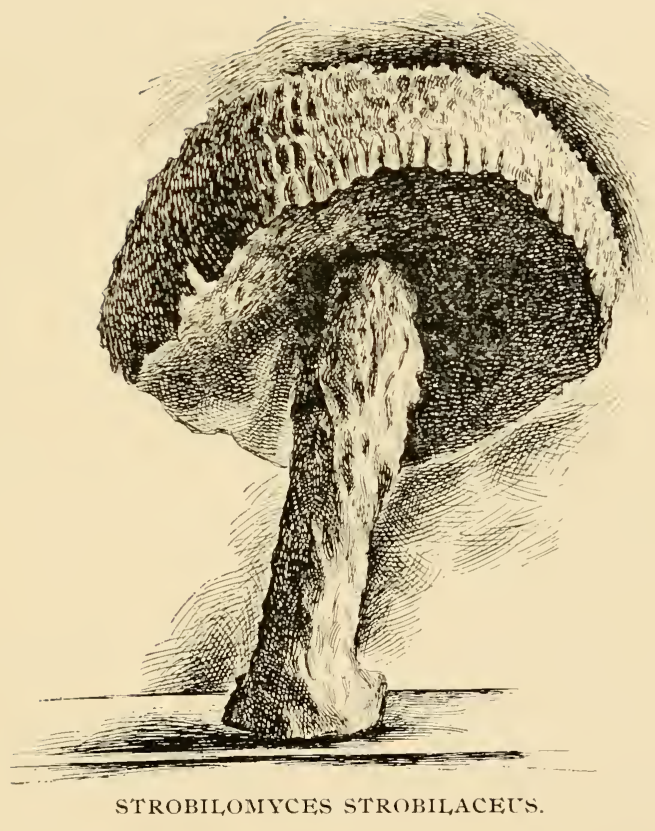



It is a question whether we have any species of the Boletinus growing in our Lehigh Valley in Pennsylvania. Some years ago I found a specimen which I considered Boletinus poroso, but after comparing it with exchange specimens I found that I had been mistaken - so I have none to record for the present. The identification of the different species of Boleti is troublesome. Fries himself admitted that no genus gave him as much trouble as the genus Boletus.

GEnus XLIV. STROBILOMYCES. Berk.

Hymenophore even, tubes not easily separable from it; large, equal. Pileus and stem distinctly squarrose, squamose, flesh tough.

\section{S. strobilaceus. Berk.}

Pileus, convex, rough with dark umber scales, two to three inches broad, margin veiled, flesh white, changing to red.

Tubes, adnate, white, angular, changing to red when bruised.

Stem, tapering upwards, sulcate at the apex, floccosetomentose.

Spores, dark brown, .0004 to .0005 inch.

Common in all our open woods.

\section{S. floccopus. Vahl.}

Pileus, convex, pulvinate, covered with an reolate fasciculate-squarrose, squamose tomentum, cinereous, at length blackish, margin veiled.

Tubes, large, grayish, depressed around the stem.

Stem, stout, lacunose above, umber-tomentose below, four to five inches long.

Spores, globose, brown, .00036 inch broad. 
According to Prof. Peck, the New York species differ only in the depressed tubes in the latter.

Equally common in our Lehigh Valley. Supposed to be edible; it has quite an agreeable nutty flavor when fresh.

\section{GenUS XLV. BOLETUS. Dill.}

Hymenium composed of easily separating tubes, distinct and easily separable from the hymenophore. Terrestrial, fleshy, putrescent, centrally stipitate fungi.

Species of the Lehigh Valley Boleti are included under the following heads or groups :

r. Luridi.-Tubes yellowish, with reddish brown mouth.

2. Viscipelles.- - Pileus viscid, tubes adnate to the stipe.

3. Subtomentosi.-Tubes adnate, pileus dry and tomentose.

4. Subpruinosi.-Pileus glabrous, tubes adnate.

5. Edules. - Tubes free, stuffed when young.

6. Calopodes.-Tubes adnate, stem beautifully veined.

7. Hyporhodii.-Tubes becoming flesh colored from the spore.

8. Versipelles.-Tubes free, whitish at first, veiled.

9. Cariosa.-Tubes white at first, then yellowish. Stem excavated, and not reticulated.

\section{Group I. Viscipelles.}

Pileus viscid, stem solid, tubes adnate, of one color.

\section{B. spectabilis. Pk. Showy Boletus.}

Pileus, convex, at first covered with a red tomentum, then squamose, viscid when moist, red, flesh pale yellow.

Tubes, at first yellow and concealed by the veil, orifices angular, adnate. 


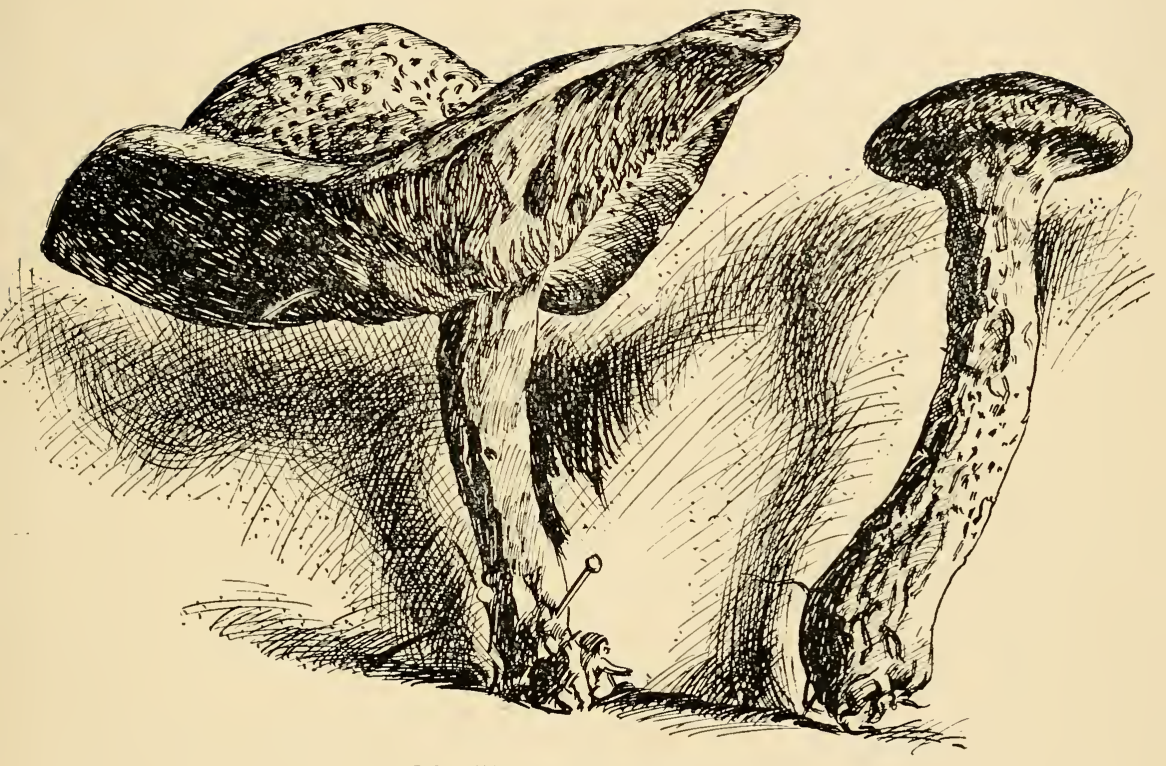

BOLETUS SPECTABILIS. 

Stem, equal, annulate, yellow above the annulus, red or red with yellow stains below.

Pileus two to five inches broad.

There are several localities in the Valley where it is quite common in its season, during August and September. Minesite woods is the best place to look for it.

\section{B. subluteus. Pk. The Yellow Boletus.}

Pileus, convex plane, viscid when moist, often obscurely virgate spotted, dingy yellow, inclining to ferruginous brown, flesh whitish to yellow.

Tubes, plane or convex, adnate, small, subrotund, yellow, becoming ochraceous.

Stem, slender, pallid or yellowish, dotted above and below the annulus with reddish glandules, annulus membranaceous, glutinous, collapsing, forming a narrow band around the stem.

Spores, subfusiform, ochraceo-ferruginous, .0003 to .0004 inch long, .00016 to .0002 broad.

Pileus one and one-fifth to three inches broad.

The yellow Boletus is not common with us, but occasionally it is found in mixed woods of pines and chestnuts.

\section{B. Americanus. $\mathrm{Pk}$.}

Pileus, thin, convex, plane, very seldom umbonate, viscid when moist, slightly tomentose when young, soon glabrous, sometimes vaguely dotted or streaked with bright red, flesh pale yellow, pinkish gray on exposure to the air.

Tubes, plane or convex, adnate, large, angular, pale yellow, becoming sordid ochraceous.

Stem, slender, never more than four lines thick, not at all annulate, yellow, brownish toward the base, marked with numerous brownish dots.

Spores, fusiform .00035 to .00045 inch long by .00016 to .0002 inch broad. 
This is quite common in our Valley. Wherever there are white pine trees you will almost be sure to find the B. Americanus in their proper season.

\section{B. inflexus. $\mathrm{Pk}$.}

Pileus, convex, compact, covered with a viscid pellicle, yellow, flesh pale yellow, margin inflected beyond the tubes, covering them, veil-like for about four lines or more.

Tubes, adnate, small, both tubes and orifices of one color.

Stem, elongated, same color as pileus or a little more pallid.

The plant stains yellow in handling.

This new species I found in Kuhn's woods, near a dried-up water pond, near Chapman's Station on the C. \& F. R. R.

Named by Prof. Peck, State Botanist of New York.

\section{B. granulatus. Linn.}

Pileus, two to three inches broad, hemispherical, at first covered with a brownish gluten, then turning yellowish, flesh thick, yellowish, does not turn blue, margin involute at first.

Tubes, at first white, then light yellow, compound, the margin distilling a pale watery fluid, which when dry gives the granulated appearance, adnate.

Stem, one inch or more high, one-half inch thick, pale yellow above, white below, granulated.

Spores, spindle shape, yellowish-ferruginous, .0003 to .00013 inch.

Abrndant in mixed woods of pine and chestnut. Minesite woods is the best locality in the Lehigh Valley. In its proper season I have seen the ground literally covered with them in all the different stages.

Some authors praise it very highly as esculent.

B. piperita. Bull. Peppery Boletus.

Pileus, convex, then plane, smooth, slightly viscid, yellow, inclining to reddish, flesh yellow, not changing color. 
Tubes, large, subdecurrent, angular, yellow, with a reddish tint.

Stem, one to two inches high, thin, more or less yellow.

Spores, oval, brown, .0003 to .00015 inch.

Found in an open woods of scrub oak, near Koch's abandoned orebed.

B. dichrous. Ellis. The Two-colored Boletus.

Pileus, convex, viscose, dull red, flesh soft, dull yellowishwhite, changing to greenish blue when wounded, finally yellow.

Tubes, subdepressed around the stem, large, unequal, straw-colored, changing color like the flesh when bruised.

Stem, thickened below, solid, corered with a red squamulose coat, except at the yellow apex, yellow within.

Spores, elliptical, .0007 inch long.

Found specimens in Kuhn's woods. Prof. Peck determined it as the above-mentioned species.

\section{Group II. Subpruinosi.}

Pileus glabrous, but more often pruinose, tubes adnate yellowish, stem equal, even, neither bulbous nor reticulated.

B. miniato-olivaceus. Frost. Olive-red Boletus.

Pileus, at first pruinose-tomentose, red, becoming glabrous and ochraceous red with age; flesh yellow, but instantly turing to a livid indigo blue, convex plane.

Tubes, bright yellow, adnate, or subdecurrent. Sensitive to change to blue.

Stem, glabrous, enlarged at the base, pale yellow, brighter yellow within, sometimes lurid at the base.

Spores, .0005 inch 1ong, .00025 broad. 
Var. sensibilis. $\mathrm{Pk}$.

I think our plant growing in the Valley is Prof. Peck's variety, for they are all very sensitive and turn to a livid blue when bruised.

Common in many of our open woods. Found some beautiful specimens in woods east of Allentown.

B. innixus. Frost. Leaning Boletus.

Pileus, convex, plane, glabrous, yellowish brown, slightly areolated when old, yellow in the interstices, flesh white.

Tubes, adnate, yellow, unchangeable.

Stem, slender, short, thickened at the base in large specimens, yellowish, streaked with brown, often bent.

Spores, .0004 to .0002 inch broad.

Found it growing on clay banks along the edge of woods near Allentown. It generally leans to one side, with a slightly crooked stem.

\section{B. pallidus. Frost. Pale Boletus.}

Pileus, convex, becoming plane or centrally depressed, soft, smooth, pallid or brownish white, flesh white.

Tubes, plane or slightly depressed around the stem, or nearly adnate, pale, whitish yellow, changing to blue when wounded, mouth small.

Stem, equal, slightly thickened at base, long, smooth, whitish, often tinged with red within.

Spores, yellow-brown.

Common in our woods.

\section{Group III. Subtomentosi.}

The species under this group are nearly the same except by the more evidently tomentose young pileus. Thus far I have only two species to record indigenous in our Valley; but those two species are quite common. 
B. subtomentosa. Fr.

Pileus, convex, plane, soft, dry, villose-tomentose, subolivaceous, concolor beneath the cuticle, often rimose areolate, flesh white.

Tubes, adnate or somewhat depressed around the stem, yellow, mouths large, angular.

Stem, stout, somewhat ribbed, sulcate, smooth or scurfy with dots.

Spores, .0004 to .0005 inch long, .00016 to .0002 broad.

This is the so-called red cracked Boletus, for when cracked the interstices are yellow. The flesh does not change to blue in our species.

Scarce in our woods. Found specimens in Dorney's woods near Allentown.

B. chysenteron. Fr. Red Cracked Boletus.

Pileus, convex or plane, soft, floccose, squamulose, often rimoso-areolate, brown or brick red, flesh yellow, changing to blue when exposed, red beneath the cuticle.

Tubes, adnate, greenish yellow, changing to blue when bruised, mouths large, angular, unequal.

Stem, subequal, fibrous striated, red or pale yellow.

Spores, fusiform, pale brown, .0004 to .0005 inch long to .00016 to .0002 inch broad. Pileus two to three inches broad.

Prof. Peck says in his Fifty-first Report: The variability of this species is quite perplexing. Two forms occur. In one form the pileus is red but fades to grayish buff. It has a persistently red, minutely scurfy stem. In the other the pileus is dark brown or olivaceous and the stem is pale red or yellow and red. In both the flesh may be either yellow or whitish, and the cracks in the pileus may be either red or pallid.

Common in open woods throughout the Valley. 


\section{Group IV. Calopodes.}

Stem stout, at first bulbous, typically venose, reticulated. Tubes adnate, their mouths not reddish.

B. ornatipes. $\mathrm{Pk}$. The Beautiful Boletus.

Pileus, convex, firm, dry, glabrous, or very minutely tomentose, grayish brown or yellowish brown, flesh yellow.

Tubes, adnate, plane or concave, mouths small, clear yellow.

Stem, firm, beautifully reticulated, yellow without and within.

Spores, ochraceous brown, .00045 to .00055 inch long, .00016 to .0002 inch broad.

This beautiful Boletus is found in seversl localities in our Valley. Koch Island.

\section{B. griseus, Frost.}

Pileus, broadly convex, firm, dry, subglabrous, gray or grayish black, flesh whitish or gray.

Tubes, adnate or slightly depressed around the stem, nearly plane, their mouths small, subrotund, white or whitish.

Stem, equal or slightly tapering upwards, distinctly reticulated, whitish or yellowish. Sometimes reddish towards the base.

Spores, almost the same in color and size as the $B$. ornatipes.

This species is quite common in our Valley. You will meet with them in quite a number of woods. It is difficult to get a specimen that is not worm-eaten. Edible.

\section{Group V. Edules.}

Tubes subfree, rounded, depressed around the stem, their mouths not at first reddish, commonly white stuffed. Stem 
stout, bulbous, not reticulated except in a few species. Flesh scarcely changeable. This group is taken from B. edules as a type.

B. separans, $\mathrm{Pk}$. Separating Boletus.

Pileus, convex, thick, smooth, often pitted or lacunose, brownish red or dull lilac, sometimes fading to yellowish on the margin ; flesh white, unchangeable.

Tubes, adnate, white and stuffed, then convex and depressed around the stem, ochraceous yellow, and sometimes separating from the stem by expansion of the pileus.

Stem, equal or slightly tapering upwards, reticulated either wholly or in the upper part only ; colored like the pileus or a little paler.

Spores, subfusiform, ochraceous.

This is one of the most common Boletus in the Valley. I at first took it for the B. edules, var. currugatus.

\section{B. edules. Edible Boletus.}

Pileus, convex, nearly plane, smooth, moist, at first compact, then soft, variable in color, grayish-red or tawny brown; flesh white, reddish beneath the cuticle.

Tubes, convex, nearly free, long, minute, white, stuffed at first, then yellow greenish.

Stem, various in length and thickness, with a coarse, fine or hardly any reticulation, white or brownish.

Spores, oblong, fusiform, .0005 to .oco6 inch long.

This species is scarce in our Lehigh Valley. You seldom meet with it in our woods. Found specimens in Minesite woods and in mixed woods near Emaus. Have not met with Prof. Peck's var. clavipes.

B. eximius. $\mathrm{Pk}$. Select Boletus.

Pileus, at first compact, convex, subpruinose, purplish brown, or chocolate color, sometimes with a faint tint of lilac, becoming smoky red, flesl grayish or reddish. 
Tubes, at first concave, stuffed, colored like the pileus, becoming paler, depressed around the stem.

Stem, stout, short, tapering upwards, abruptly narrowed at the base, minutely furfuraceous, covered like the pileus, purplish gray within.

Spores, subferruginous, .00045 to .0006 inch long, .0002 to .00025 inch broad.

This species was first found some years ago in an open oak woods near Cedar Creek in our Valley. I had it determined by Prof. C. H. Peck.

\section{Group VI. LURIDI.}

In this tribe the tubes and their mouths are differently colored, the latter being red or some shade of red (lurid). By this character the species are easily distinguished from those of other tribes.

\section{B. alveolatus. B. \& C. Alveolate Boletus.}

Pileus, convex, shining, bright crimson or maroon color, sometimes paler, with patches of yellow; flesh firm, white, quickly changing to blue where wounded.

Tubes, adnate, yellow, with maroon-colored mouths; hymenial surface secreting a glary fluid in drops.

Stem, rough, with deep reticular depressions or alveolate; with a bright red or yellow margin.

Pileus two to three inches broad.

Spores, yellow brown, .0005 to .0006 inch long, .00016 to .0002 inch broad.

This species is quite common, and on account of the bright red pileus it is not easily overlooked. Chaparral woods.

B. 1uridus, Lurid Boletus.

Pileus, pulvinate, tomentose, umber, then subviscid, dingy, flesh yellow, turning quickly to blue where wounded. 
Tubes, free, yellow, becoming greenish, mouths round, vermilion, becoming orange.

Stem, stout, vermilion, somewhat orange at the top ; reticulate or punctate.

Pileus two to four inches broad.

Spores, .0006 inch long, .00035 inch broad.

The lurid Boletus is found not only in our lowlands, but also on the mountainside woors. Considered very poisonous.

\section{Group VII. Versipelles.}

Tubes at first white or whitish, minute, round, equal, forming a convex stratum free from the stem.

\section{B. sordidus. Frost.}

Pileus, convex, subtomentose, brown; flesh white, turning greenish.

Tubes, free, long, at first white, changing to bluish green.

Stem, brown, smaller at the top, and greenish at the apex.

Pileus about two inches.

Spores, .0004 to .0005 inch long, .0002 inch broad.

Scarce. Found in Spring Creek woods.

\section{B. versipelles. Orange Cap Boletus.}

Pileus, convex, dry, at first compact, minutely tomentose, then squamose or smooth, reddish, or orange red, the margin appendiculate with the inflexed remains of the membranaceous veil ; flesh white or grayish.

Tubes, concave or nearly plane, free, minute, sordid white, their mouths gray.

Stem, equal or tapering upwards, solid, rugose-squamose, whitish or pallid. 
Spores, .00055 to .0007 inch long, .00016 to .00025 inch broad.

Pileus two to six inches broad.

This beautiful robust Boletus is not very common in the Lehigh Valley. I found it in several localities. Dearolf's crossing, Salisbury Township ; Bastian's woods, near the Auburn \& Allentown Railroad.

\section{B. scaber. Fr.}

Pileus, convex, glabrous, riscid when moist, at length rugulose or rivulose.

Tubes, free, convex, white, then sordid, their mouths minute, rotund.

Stem, solid, attenuated above, roughened with fibrous scales.

Spores, same as in B. versipelles.

Pileus one to four inches broad.

Common in open woods. You will meet with the different varieties in the same localities. Var. fuliginous is often met with.

B. chromapes. Frost. Chrome-footed Boletus.

Pileus, convex, plane, slightly and sometimes fasciculately tomentose, pale red or pinkish; flesh white, unchangeable.

Tubes, subadnate, more or less depressed around the stem, white or whitish, becoming brown.

Stem, equal, tapering upwards, scabrous-punctate, whitish or pallid, chrome yellow at the base both without and within, sometimes reddish above.

Spores, oblong, .00045 to .00055 inch long, .000 6 to .0002 inch broad.

Pileus two to four inches broad.

Common in the Valley.

\section{Group VIII. Hyporhodii.}

'Tubes adnate to the stem, whitish, then white incarnate from the rosy spores. 


\section{B. felleus. Bull.}

Pileus, convex or nearly plane, firm, becoming soft, glabrous, even, variable in color, pale yellowish, grayish brown, reddish brown, or chestnut; flesh white, often changing to flesh color where wounded, taste bitter.

Tubes, adnate, long, convex, depressed around the stem, mouths angular, white, becoming tinged with flesh color.

Stem, variable, equal, tapering upwards, short or long, sometimes bulbous at the base, subglabrous, reticulated upwards. Colored like or a little paler than the pileus.

Spores, .0005 to .0007 inch long, .000I6 to .0002 inch broad, flesh colored.

Common in woods and pastures throughout the Valley.

\section{B. gracilis. $\mathrm{Pk}$.}

Pileus, convex, glabrous or minutely tomentose, rarely squamulose, ochraceous brown, tawny brown, or reddish brown ; flesh white.

Tubes, plane or convex, depressed around the stem, nearly free, whitish, becomish pale flesh colored, mouths subrotund.

Stem, long, slender, equal or slightly tapering upwards, pruinose or minutely furfuraceous, even or marked by slender elevated anastomosing lines which form long narrow reticutions.

Spores, .0005 to .0007 inch long, .0002 to .00025 inch broad.

Pileus one to two inches broad.

Found it growing in woods near Wescoesville.

\section{Genus IX. CARIOSI.}

Stem never reticulated, stuffed with a spongy pith, at length commonly excavated, tubes at first white, then often yellowish, mouths minute, round. 


\section{C. castaneus. Bull.}

Pileus, convex, plane or depressed, firm, even, dry, minutely velvety tomentose, cinnamon or reddish-brown; flesh white, unchangeable.

Tubes, free, short, small, white, becoming yellowish.

Stem, equal or tapering upwards, even, stuffed or hollow, clothed and colored like the pileus.

Spores, .0004 to .0005 inch long, .00025 to .0003 inch broad.

Pileus one and one-fifth to three inches broad.

This species does not seem to be partial to woods, for you will find it growing under isolated trees along the roadside. Along the road from Trexlertown to Allentown, near a place called Crocksville.

Genus XLVII. POLYPORUS. Fr. Hym.

Hymenophore descending into the trama of the pores, which are not easily, if at all, separable, and changed with them into a distinct substance.

The trama is different in substance from the hymenophore, and often in color.

The better to identify the different species they are divided into different sections.

Section i. Mesopus. Pileus entire, stem central.

$$
\text { P. flavovirens. B. \& Rav. }
$$

Pileus, three to six inches broad, expanded, funnel-form, fleshy; flesh white, tomentose, yellow, green or olivaceous, rimose when old.

Pores, medium, toothed, white, decurrent down the white, tapering stem.

This is quite common in our woods, growing in groups of fifteen to twenty plants under one tree. Dorney's woods near Allentown. 


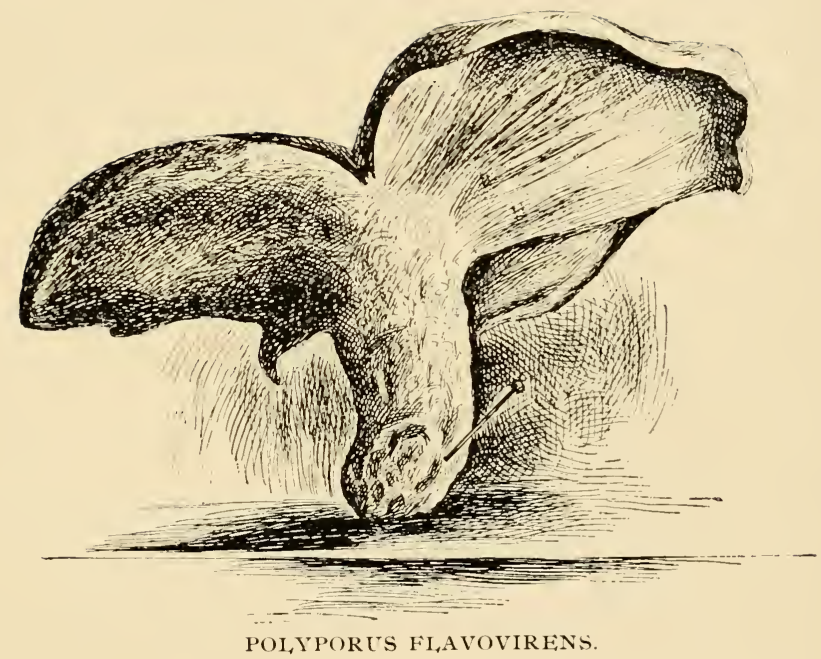

POI,YPORUS FLAVOVIRENS. 

P. brumalis. Fir.

Pileus, slightly fleshy and tough, leathery, subumbilicate, zoneless, in the first season dingy villous, in the second squamulose, becoming smooth, pallid.

Pores, oval, angular, slender, acute, denticulate, white.

Stem, thin, slightly bulbous at the base, hirsuto-squamulose, pale.

This species you will find throughout the Valley growing on halfrotten sticks.

\section{P. arcularius. Batsch.}

Pileus, thin, plane, brownish, funnel-shape, margin covered with stiff hair.

Pores, shallow, rotund, brown.

Stem, thin, scaly, attached to rotten logs.

Common in woods on decayed logs.

\section{P. rufescens. Fr.}

Pileus, spongy, flesh soft, unequal, wooly.

Pores, large, sinuose and lacerated, white or flesh colored.

Stem, short, irregular, tuberous at the base.

On the ground around stumps. Common near Trexlertown.

P. perennis. Fr.

Pileus, coriaceous, thin, plane, then infundibuliform, velvety, becoming smooth, zoned.

Pores, minute, angular, acute, at first veiled, then naked and torn.

Stem, firm, bulbous below, brown.

Spores, oval, white, .ooor to . rooor 8 inch.

A nice species of Polyporus. Not common. Found specimens in Spring Creek woods and Glen Onoko. 
P. Schweinitzii. Fr.

Pileus, thick, spongy, then corky, strigoso-tomentose, rough, bright brown.

Pores, large, variable, and torn, sulphur greenish.

Stem, thick, very short or obsolete, ferruginous.

Very scarce in the Valley. Only met with it in one locality and that was in the Minesite mixed woods of pine and chestnut.

Section 2. Pleuropus. Stem lateral.

P. picipes. Fr.

Pileus, fleshy, rigid, coriaceous, even, smooth, depressed behind.

Pores, decurrent, rounded, small, tender, white, at length reddish-gray.

Stem, excentric and lateral, equal, firm, at first velvety, then pitch black below.

Common on old stumps throughout the Valley. Has a liking for willow stumps.

P. 1ucidus. Fr. Shining Polyporus.

Pileus, corky or woody, flabelliform, sulcate, rugose, yellow, then reddish chestnut, varnished and shining as well as the lateral, equal stem.

Pores, long, minute, white, then cinnamon.

Stem, reddish, varnished, sometimes sessile.

Pileus two to six inches broad.

Common on oak stumps. There are many different forms, varying so much so as to disguise the natural type. The pileus may be stipitate, it may be sessile, or assume some other fantastic form. The most wonderful specimen that I ever saw was found in Schuylkill County, by a Mr. Horn, of Bethlehem, Pa., who may still be in possession of it. There were at least fifteen fully developed pilei on different branches, with odd forms. Some mimicked a profile of a man's face ; some were in the form of a boot; while others were elongated in the form of fingers. 
P. elegans. Fr. Elegant Polyporus.

Pileus, fleshy, soon becoming woody, expanded, even, smooth, pallid.

Pores, plane, minute, subrotund, pallid, yellowish white.

Stem, excentric, even, smooth, pallid, base from the first abruptly black.

Common on rotten branches lying on the ground all throughout the Valley.

SeCtion 3. Marisma. Divided into numerous pileoli.

P. anax. Berk.

Pileoli, very numerous, brittle, dimidiate expanded, at length spathulate, even, alutaceous.

Pores, firm, obtuse, shallow, white, then brownish.

Stems, or branches united into a very short trunk.

This species is often confounded with the old P. intybaceous, which has the spores oval, whereas our species has them round.

Common in chaparral ridgewoods.

\section{P. giganteus. Fr.}

Pileoli, imbricated, fleshy, tough, somewhat coriaceous, flaccid, somewhat zoned, bright brown, then dark brown, depressed behind, pileoli very numerous.

Pores, minute, shallow, round, pallid, at length torn.

Stem, branched, connate from a common tuber.

This is perhaps the largest fungus growth to be found in our Valley. I found specimens three feet or more in diameter growing on stumps. The flesh turns fuscous when bruised.

Common in nea ly every wood in the Valley.

\section{P. Berkleyi. Fr.}

Pileoli, fleshy, tough, becoming hard and corky, large, many in a head, subzonate, alutaceous. 
Stem, short or none, arising from a long and thick caudex. Pores, large, irregular, angular, pale.

On the ground, near superficial roots of trees. They grow to an immense size, equal to the P. giganteus. Throughout the Valley.

\section{P. umbellatus. Fr.}

Pileoli, numerous, broad, fuliginous, rufous, entire, umbilicate.

Pores, minute, white.

Stem, elongated, separate, united at the base, white.

Found on a rotten stump in woods near Cedar Creek woods.

\section{P. sulfureus. Fr.}

Pileoli, broad, imbricated, undulated, nearly smooth, egg yellow, flesh cheesy.

Pores, minute, often formed of inflexed masses.

Stem, often connate into a yellow unrecognizable mass.

Common on decayed willow branches. Spores white.

\section{Section 4. Apus. Without a stem.}

This section is divided into four groups, viz:

I. Anodermei-without a separate cuticle on the pileus.

2. Placodermei-pileus indurated, covered with a more or less hard crust.

3. Inodermei-pileus at first dry, covered with a thin, more or less fibrous, cuticle.

4. Resupinate-without a pileus.

Group I. P. rutilans. Fr. Reddish Polyporus.

Pileus, fleshy, tough, thin, soft, at first villose, then smooth, not zoned, tawny cinnamon, growing pale, of the same color within. 
Pores, short, minute, equal, acute, cinnamon.

You can find it on decayed logs, lying on a wet place. Lehigh Valley.

\section{P. adustus.}

Pileus, more or less imbricated, fleshy, tough, firm, thin, villous, cinereous, margin straight, blackish.

Pores, short, minute, round, obtuse, whitish, soon cinereous brown.

\section{P. gilvus. Schw.}

Pileus, corky, woody, hard, effusco-reflexed, imbricate and concrescent, subtomentose, then scabrous and uneven, reddish yellow, then subferruginous, the margin acute.

Pores, minute, round, entire, brownish-ferruginous.-Morgan's Mycologic Flora of the Miami Valley, Ohio.

common on all kinds of decayed logs throughout the Valley.

P. dichrous. Fr.

Pileus, fleshy, tough, thin, soft, effusco-reflexed, even, silky, white.

Pores, short, minute, round, obtuse, brown-cinnamon.Morgan's Mycologic Flora of the Miami I'alley, Ohio.

This is rather an unliappy species on account of its different synonyms:

Glæoporus conchoides, Fr., Mont., and Polyporus nigropurpurascens, Schw. It was placed under another genus by Montgomery, Glieoporus conchoides, on account of the gelatinous hymenium.

\section{Group 2. Placodermei.}

Species under this group are also called Fomes.

P. applanatus. Fr. Flattened Polyporus.

Pileus, expanded, tuberculose, sulcate zoned, smooth, hard, cinnamon, becoming white, crustaceous, rigid, within solt, floccose, margin tumid, white, then cinnamon. 
Pores, very small, subferruginous, orifice whitish, brownish when bruised.

On living and dead trunks of different species of trees.

This is one of the most common species of ligneous fungi in the Valley. They are called shelves by the common people. The hymenium or under surface is white, as if whitewashed; this white plane surface is used to delineate pictures of trees, houses, etc., which are permanent. I have a specimen on which I delineated tents, copied from the cover of "George Kennan's Life in Siberia" five years ago, and they are as plain as when put on.

\section{P. rimosus. The cracked Polyporus.}

Pileus, pulvinate-ungulate, much dilated, deeply concentrically sulcate, cinnamon, then brown or blackish and exceedingly rimose; context very hard, fibrous-radiating, tawnyferruginous; the margin broad, pruinate-velvety, rather acute.

Pores, minute, indistinctly stratified, tawny-ferruginous, the mouths rhubarb color.-Morgan's My'cologic Flora of the Miami Valley, Ohio.

This is only found on locust trees, on decayed spots, and very scarce in the Valley.

\section{P. ribes. Currant-Bush Polyporus.}

Pileus, corky, coriaceus, rather soft, plane, velvety, ferruginous, then umber, margin acute, slightly zoned.

Pores, short, small, naked, tawny.

The currant-bush Polyporus grows at the neck of the root and stem. Not common in the Lehigh Valley. Found specimens in Salisbury Township, near Emaus, in John Reinhard's garden.

\section{P. salicinus. Fr.}

Pileus, woody, hard, undulate, smooth, in great part resupinate, margin short, obtuse, cinnamon, then brown.

Pores, very small, round, ferruginous, cinnamon, hard when dry.

Common on dead branches of swamp willows. 


\section{P. albellus. Pk.}

Pileus, thick, sessile, convex or subungulate, subsolitary, two to four inches broad, one to one and a half thick, fleshy, rather soft, the adnate cuticle very thin, smooth or sometimes slightly roughened by a slight stigose tomentum, especially toward the margin, whitish, tinged more or less with fuscous; flesh pure white, odor acidulous.

Pores, nearly plain, minute, subrotund, about two lines long, white, inclining to yellowish, the dissepiments thin, acute.

Spores, minute, cylindrical, curved, white, .00016 to .0002 inch long. - Peck's Reports.

Common on poplar logs throughout the Valley.

\section{P. borealis. Fr.}

White, then yellowish, 5 cent. ( 2 in.) and more broad and thick.

Pileus, spongy, then corky, compact, somewhat pulvinate, hairy, internally composed of parallel fibres, margin spreading.

Pores, adnate, unequal, sinuoso-flexuous and torn, white.

This plant is quite common on oak stumps in Minesite woods.

\section{P. connatus. Fr.}

Pileus, corky and woody, effused, more or less imbricated, confluent, velvety, white within and without.

Pores, minute, roundish, white.

Common at the base of living trees where there is some moss growing.

Group 3. Inodermei. Pileus with a dry cuticle.

P. versicolor. Different-colored Polyporus.

Pileus, coriaceous, thin, rigid, plane, depressed behind, velvety, even, and shining; variegated with colored zones.

Pores, minute, acute, and torn, white, then pallid. 
This is one of the most common dry Polypora fungi growing in the Valley. There is barely a half-decayed stump that does not have a beautiful rosette growing. It does not seem to be very particular for a host, for it grows on any kind of wood.

\section{P. pergamenus.}

Pileus, coriaceous, thin, effuso-reflexed, villous, zoned, cinereous-white, with colored zone.

Pores, unequal, torn, violaceous, then pallid.

Almost as common as the versicolor and has the same habit.

P. cinnabarina. Schw. Cinnabar Polyporus.

Pileus, dry, more or less spongy, flesh light or yellowish red, fibrous on top of pileus.

Pores, carmine, small, round, entire.

This species is easily identified by its beautiful carmine red color, of both pileus and pores.

Common on decayed cherry logs.

\section{P. hirsutus. Fr.}

Pileus, corky, coriaceous, convex plane, hairy, with rigid bristles, zoned or rather sulcate with concentric ridges, of one color, which is white.

Pores, round, obtuse, white or grayish, then brown.

Common on different kinds of decayed wood.

\section{P. cupulæformis. B. \& C.}

Pileus, cup-shaped, resupinate, attached to its host with a thin pellicle.

Pores, small, brown, shallow.

Common on decayed chestnut branches. This is a peculiar species inasmuch as it looks like a Peziza. When I first found it, I took it for a dry Peziza, but could not detect any ascospores, so I was at a loss until Prof. C. H. Peck helped me out of the dilemma. 
Group 4. Rersupinatus. No pileus.

The species under this head are also called Poria.

P. inermis. Ellis.

This is a common yellow-pored Polyporus growing on dry poplar limbs, becoming black.

Circumference, marginate, adnate.

P. vulgaris. Fr.

Wholly composed of firm, dry, crowded, small, round, nearly equal, pores.

Circumference, broadly effused, thin, closely adnate, even, white.

Common on old moist boards.

P. Vaillantii. Vaillant's Polyporus.

Circumference, white, free, forming fibrous ribs which unite into a membrane.

Pores, slightly rufescent.

On cordwood and stumps, to hasten the decay. A good friend of the farmer to rid new land of stumps.

\section{P. incarnatus.}

Whole plant flesh color. Pores small flesh color. Generally on dry hickory limbs.

Genus XLVIII. MYRIADOPORUS. Pk.

This new genus was found by Prof. Peck on the cellular structure of several Polyporoid species. They are supposed to be abnormal forms of some polyporus species. 
M. rubra. $\mathrm{Pk}$.

This species is supposed to be a form of Polyporus salmonicolor, Ellis.

There is a beautiful specimen growing near Trexlertown on a halfdecayed poplar log.

\section{GENUS XLIX. TRAMETES.}

Hymenophore descending into the trama of the pores without any change.

T. suaveolens. Fr. Sweet-scented Trametes.

Pileus, corky, soft, villous, zoneless, white.

Pores, round, large, brownish white, odor like aniseed.

Common on willow throughout the Valley.

T. sepium.

Pileus, corky, becoming hard, slightly zoned, with a darker zoned margin.

Pores, elongated, anastomosing.

Common on half-decayed fence-posts throughout the Valley.

\section{Genus L. DADALEA. Fr.}

Pores labyrinthiform, trama same in substance and color as hymenophore.

D. quercinus. $\mathrm{Pk}$. Oak Dædalea.

Pileus, corky, rugulose, uneven, zoneless, becoming smooth.

Pores, at first round, then broken into contorted or gill-like labyrinthiform sinuses, edge obtuse. 
They grow to an immense size in the Valley. I have seen them to measure from six to eight inches across.

Common on oak stumps.

D. confragosa. Pk. Willow Dædalea.

Pileus, corky, convex, coriaceous at first, then rigid, rough, subzonate, reddish brown.

Pores, sometimes round like a Polyporus, sometimes elongated into gill-like plates, like a Lenzites.

The typical labyrinthiform is very seldom met with in our Valley. This same species has been taken for a different species, the D. cratægus. Common on willows.

\section{D. unicolor. Fr. One-color Dædalea.}

Pileus, coriaceous, villous-strigose, cinereous, and zones of the same color.

Pores, labyrinthiform, at length torn and toothed.

Common on dead branches of maple. It is called unicolor on account of the similar color of the hymenium and the pileus.

\section{Genus LI. FAVOLUS. Fr.}

Hymenium alveolate, radiating, formed of the densely anastomosing gills, elongated. Spores white. Dimidiate, somewhat stipitate.

T. canadensis. Klotsch.

Pileus, fleshy, tough, thin, reniform, fibrillose, scaly, and tawny, becoming pale and glabrous.

Pores, or alveoli angular, elongated, white at first, then straw color.

Stem, excentric, lateral, very short or none.

Common on dead hickory branches throughout the Valley. Favolus Europeæ and Favolus alveolarius, D.C., are considered the same, only named in different periods of growth, young or mature specimens. 


\section{GenUS LII. MERULEUS. Fr.}

Hymenium soft, waxy, forming shallow pores, reticulated, forming folds.

M. tremellosus. Schrad.

Resupinate, reflexed, fleshy tremelloid, tomentose, white, margin dentate-radiate, folds porose, variable, pinkish.

Common on logs and stumps.

\section{M. corium. Fr.}

Resupinate, effused, soft, papery, circumference free, white, villous. Hymenium netted, porose, pallid, tan color.

On dead limbs, not very abundant.

\section{M. rubellus. $\mathrm{Pk}$.}

Pileus, sessile, confluent and imbricated, repand, thin, convex, somewhat tenacious, subtomentose, glabrate, red, becoming pale. Hymenium whitish or reddish; the folds much branched, porose-anastomosing.

Pores, white, elliptic, .004 to .005 mm. long.-Morgan's Mycological Flora of the Miami Valley, Ohio.

This species is very scarce in our Lehigh Valley. I only remember finding it once on a soft wood log near Chapman's Station.

\section{Genus LiII. FISTULINA. Fr.}

Hymenophore fleshy. Hymenium inferior. There is only one species recorded belonging to this family, viz:

\section{F. hepatica. Liver Fungus.}

Pileus, dimidiate, red juicy, undivided, flesh mottled like beet root, pileus covered with a more or less gelatinous cuticle, 
which is furfuraceous tuffed. Hymenium papillose; papilla at length elongated, forming distinct tubes, which are beautifully tinted vermilion.

This is common on chestnut stumps, and on account of its size and red color it is not esily overlooked. It is sometimes called beefsteak fungus on account of its edible qualities. Edible. 
ORDER III. HYDNEI. Fr.

Hymenium inferior or amphigenous, at first definitely protuberant, spread over persistent spines, bristles, teeth, tubercles, or papillæ. Fr. Epicr.

The following genera are included :

Hydnum.-Spines discrete at the base.

IRPEX. - With gill-like teeth, concrete with pileus.

RADULUM.-Hymenium with irregular tubercles.

PHLEBIA.-With crowded folds and wrinkles.

GRANDinia.-Covered with granules.

\section{Genus LIV. HYDNUM.}

Hymenium awl shape, spines at first papilliform, then elongated, distinct at the base.

\section{H. repandum. Linn.}

Pileus, fleshy, compact, more or less repand, nearly smooth, pale yellow, irregular in form, excentric; flesh pallid, pileus two to three inches broad.

Spines, unequal, conical, entire or sometimes bifid, or even compressed, not changeable, whitish.

Stem, short, thick, solid, paler than the pileus.

Spores, white, round with a small papilla at one end.

This is not as common any more as years ago. I remember fifteen or twenty years ago you could find specimens in nearly every woods in the Valley, whereas you seldom meet with a specimen now. Edible.

\section{H. imbricatum. Linn. Imbricated Hydnum.}

Pileus, fleshy, plane, slightly umbilicate, tessulated scaly, floccose, not zoned, number; two to three inches broad; flesh reddish, margin rounded. 
Spines, entire, numerous, short, grey ish white.

Stem, short, thick, firm, whitish.

Spores, brown, .00025 to .0002 inch.

On the ground in mixed wood of pine and chestnut. Common in Minesite woods. Edible.

\section{H. compactum. Fr.}

Pileus, compact, tuberculate, undulated, cinereous, or brownish, commonly downy, flesh with a bluish tint.

Spines, brown, white at the tips.

Stem, deformed, tuberculate, short.

Pileus from one to six inches broad.

This deformed species is common near Cedar Creek, and other localities in the Valley.

H. zonatum. Batsch. Zoned Hydnum.

Pileus, thin, coriaceous, expanded, deeply umbilicate, zoned rugose, margin pale, ferruginous.

Spines, slender, pale fuscous, nearly the color of the pileus. Stem, nearly equal except the base which is tuberculate.

Not as common as the H. compactum. Chaparral woods. Not edible; too tough.

H. graveolens. Del. Strong-scented Hydnum.

Pileus, soft, soon becoming hard, coriaceous, not zoned, but beautifully marked with a white center in contrast with the umber margin.

Spines, short, white, or light grey.

Stem, slender, tapering downwards.

Has a strong odor of sweet melilot. In woods near Emaus.

H. erinaceus. Bull. Hedgehog Hydnum.

Tuberculiform, growing in a mass, with the spines on top or pendant. 
Pileus, four to six inches broad, often consisting of smaller pileoli, giving it the appearance of a hedgehog.

Spines, white, elongated, pendulous.

I am not certain about the identity of this species. It may be the Hydnum caput-ursi, for in appearance they are so much alike. I forwarded a specimen to Prof. Burt, of Middleburg, Vt., who made it $\mathbf{H}$. caput-ursi.

\section{H. ochraceum. Per.}

Pileus, effuso-reflexed, coriaceous, thin, zonate ochraceous, minute, pinkish yellow, often for a long time resupinate.

This is common on decayed willow branches all throughout the Valley. You seldom meet with a pileate form, and if you do it is merely a narrow rim.

H. septentrionale. Fr.

Rare; specimen found in Spring Creek woods and determined by Prof. C. H. Peck.

\section{GENUS LV. IRPEX.}

Lignatile, teeth connected at the base, otherwise like Hydnum.

I. crassus. B. \& C.

Effused, crustuso-adnate, white, circumference determinate.

Spines, compressed, springing from a porous base, connected.

Common on oak fencerails throughout the Valley.

I. 1acteus. Fr.

Pileus, membranaceous, clothed with stiff hair, more or less sulcate, milk white.

Spines, compressed, radiate, margin porous.

You will find it more often on hickory stumps. 
Genus LVI. RADUI,UM. Fr.

Lignatile, hymenium with obtuse tubercles.

R. pallidum. B. \& C.

At first orbicular, then confluent and effused, with a narrow reflexed tomentose margin, pallid, Tubercles terete, short, deformed, scattered or sometimes collected in lines or groups. -Morgan's Mycologic Flora of the Miami Valley, Ohio.

On alder branches.

\section{Genus LVII. PHLEBIA. Fr.}

Lignatile, hymenium with crowded folds and wrinkles.

P. cinnabarina. Schw.

Effused, even, or encrusting on dalf-decayed logs, of a bright cinnabar color.

Common on old, decayed logs.

\section{Genus LVIII. GRANDINIA.}

Lignatile, hymenium waxy when wet, granulated when dry, granules obtuse, entire, permanent.

\section{G. granulosa.}

Waxy, effused, agglutinate, tan colored, circumference determined.

You will find it as a dirty white crust, covering some soft wood. Jungle near Trexlertown, $\mathrm{Pa}$. 


\section{ORDER IV. THELEPHOREI.}

Hymenium even, coriaceous or waxy, costate, or papillose. The following genera are included under this order:

CRATERELLUS.

THELEPHORA.

LACHNOCLADIUM.

STEREUM.

HYMENOCH ETE.

Corticium.

CyPHELLA.

Exobasidium.

Genus LiX. CRATERELLUS. Fr.

Fleshy, hymenium even, smooth, at length rugose, putrescent when old.

\section{1utescens. Fr.}

Pileus, tubæform, soon pervious, undulated pruinose, yellowish.

Stem, hollow, yellow.

Hymenium, costate, folds far apart.

Scarce in chaparral ridgewoods.

\section{C. cornucopoides. Fr.}

Pileus, membranaceous, tubæform, squamulose, dingy black.

Stem, tapering downwards, and expanded upwards, color same as pileus.

Hymenium, rugulose, greyish.

This is quite common in our woods, growing in groups on the ground. Was considered poisonous at one time. The Germans called it the Todten Trumpete. It is now known to be edible. 


\section{C. clavatus.}

Pileus, 5 cent. ( 2 in.) broad, somewhat light yellowish, fleshy, turbinate, truncate or depressed, flexuous, unpolished, attenuated into the solid stem; flesh thick, white.

Hymenium, even, then corrugated, purplish then changing color.-Stevenson's British Fungi.

Found scattered specimens in woods near Cedar Creek.

\section{GENUS LX. THELEPHORA.}

Hymenium costate or ribbed, of a tough, fleshy substance, more or less piliate.

\section{T. palmata. Fr.}

Pileus, palmately branched from a common stalk, brown, branches flat, even, tips fimbriated. When freshly gathered it has a fetid odor.

Kuhn's woods, near Chapman's Station, on the Catasauqua \& Fogelsville Railroad.

\section{T. laciniata. Pers.}

Coriaceous, soft, incrusted, brown, pilei imbricated, fibrous squamose, margin fimbriated, at first white, hymenium inferior, papillose.

Not very common. Jungle near Trexlertown.

\section{T. Schweinitzii.}

Cæspitose, white or pallid. Pilei soft-coriaceous, much branched; the branches flattened, furrowed and somewhat. dilated at the apex.

Stems, variable in length, often connate or fused together into a solid base.

Hymenium, even, becoming darker colored.-Morgan's My'cologic Flora of the Miami Valley, Ohio. 


\section{T. cristata. Fr.}

Incrusting, tough, pallid, passing into branches, branches cohering into a mass, with the apices fimbriated.

Hymenium, papillose, whitish grey.

On branches and stalks of weeds.

\section{Genus LXI. IACHNOCLADIUM.}

Pileus coriaceous, tough, repeatedly branched; the branches slender or filiform, tomentose. Hymenium amphigenous. Fungi slender and much branched, epixylous or terrestrial.

\section{I. semivestitum. B. \& C.}

Coriaceous, pale or sordid brown, tomentose.

Pileus, much branched from a slender stipe of variable length, expanded at the angles; the branches filiform, straight, somewhat fasciculate, glabrous at the tips and paler in color.Morgan's Mycologic Flora of the Miami Valley, Ohio.

Very common on the ground in swampy localities.

\section{GENUS LXII. STEREUM.}

Hymenium even, separated from the pileus by an intermediate fibrous stratum. Not beset with bristles.

S. versicolor.

Pileus, effused, reflexed, zoned with different colors like unto Polyporus versicolor.

Hymenium, even, smooth, brown.

Common on old trunks of different species of trees. 


\section{S. spadiceum. Fr.}

Pilei, spreading, finally reflexed, villous ferruginous, margin rather obtuse, white, even beneath, smooth and brownish, bleeding when bruised.

Common on stumps.

\section{S. hirsutum. Hairy Stereum.}

Pileus, coriaceous, effused, strigose, somewhat zoned, becoming pallid; margin obtuse.

Hymenium, pale yellow, even, smooth, naked, juiceless.

On stumps and hemlock lumber.

\section{S. radians. $\mathrm{Pk}$.}

Coriaceous, rigid.

Pileus, effused and reflexed, radiate-virgate with innate fibres, pallid with bay zones, glabrate, shining.

Hymenium, even, glabrous pallid.-Morgan's Mycologic Flora of the Miami Valley, Ohio.

S. albobadium. Schw. The White-brown Stereum.

At first resupinate, bright brown with a white border ; soon confluent and effused with a narrow submembranaceous margin; the margin undulate or subpileate, thin, subzonate, brown.

Hymenium, bay brown, somewhat velvety.

Common on dry shrubbery.

\section{Genus LXIII. HYMENOCHAETE.}

Hymeniun same as stereum except that it is beset with stiff colored bristles. 


\section{H. rubiginosa. Lev.}

Pileus, rigid effuso-reflexed, velvety, dark rubiginous, intermedium stratum tawny ferruginous.

Hymenium, ferruginous, velvety.

Common on old weeping willow stumps.

\section{H. curtisii. Berk.}

Pileus, coriaceous, effuso-reflexed, brown, slightly sulcate. Hymenium, even, velvety with brown bristles.

Common on half-decayed oak branches.

\section{H. agglutinans.}

Common on living alder whips, about the only stereum growing on living wood.

\section{H. corrugata.}

Effused, crustaceous, spread over different kinds of dead wood, much cracked, and corrugated when dry, dark lead color.

In woods near Fogelsville, $\mathrm{Pa}$.

\section{GenUs I.XIV. CORTICIUM. Fr.}

Hymenium soft and fleshy when moist, collapsing when dry, often rimose.

\section{1acteum. Fr.}

Membranaceous, milk white beneath.

Hymenium, waxy when moist, cracked when dry.

Common on hickory branches.

\section{1æve. Fr. Even Corticium.}

Membranaceous, villoso-fibrillose beneath, circumference fibrous.

Hymenium, even, flesh color.

On different kinds of dry wood. 


\section{C. salicinum.}

Effused, spreading over willow bark, dark purple at first, then pruinose with the white spores swelling when moist, becoming membranaceous when dry.

Common on willow branches throughout the Valley. Received the name from its growing on willow.

\section{Sambucum.}

Effused on elder bark, white, cracked when old and dry. Common on dry elder bark.

\section{C. ochraceum.}

Effused, even, waxy, white at the circumference, ochraceous towards the center.

On hemlock boards in lumber yards.

C. incarnatum. Flesh-colored Corticium.

Waxy when moist, rigid when dry, agglutinate.

Hymenium, red, flesh color.

Common on dead chestnut trees in our woods.

C. cinereum. Fr. Ash-grey Corticium.

Waxy when moist, rigid when dry, agglutinate.

Hymenium, cinereous, with a delicate bloom, which when examined are papilloid elevations. Cooke has made a separate genus on this character, and named it Peniophora cinerea.

Common on dead branches.

Genus LXV. EXOBASIDIUM. Pk.

'Tuberculate, green, covered with a white bloom when shedding spores. Parasitic on ericacer. 
E. azaleæ. Pk.

Transforming the flowers of azalea nudiflora into an applelike excrescence. They are from one to two inches in diameter, with an acid taste.

They are known by the common folks as honeysuckle apples, and eagerly eaten by voracious schoolboys. At maturity they are covered with white basidiospores. Hence the name Exobasidium, outside spores.

Genus. LXVI. CYPHELLA. Fr.

Cup-shaped, elongated behind, hymenium inferior.

C. fulva.

The only species found in the Valley. Common on dry poplar branches near Allentown, Pa. 


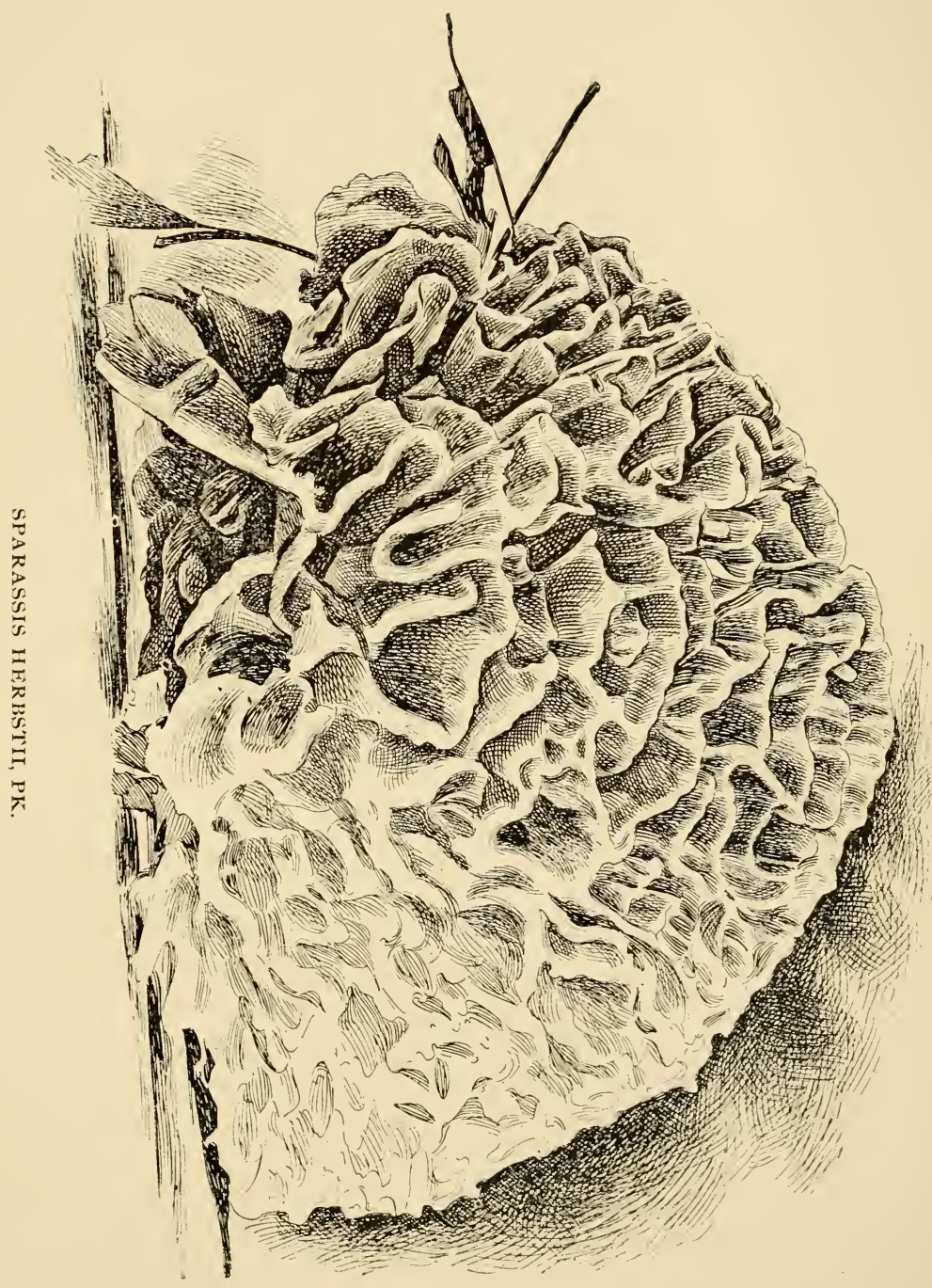





\section{ORDER V. CLAVARIEAE. Corda,}

Hymenium scarcely distinct from the hymenophore, vertical, amphigenous, reaching to the apex, even, at length wrinkled. The following genera are included, viz:

Sparassis.-Fleshy, frondose, laciniate.

Clavaria. - Stem branching, dry.

CALOCERA.-Gelatinous, then horny.

TyPHUlA. - Stem flaccid, thread-like.

Pistillaria.-Waxy, then horny.

GenUs LXVII. SPARASSIS. Fr.

Fleshy frondose, branches laciniate.

\section{S. Herbstii. Pk.}

Plant much branched, forming tufts four to five inches high and five to six inches broad, whitish, inclining to ereamy yellow, tough, moist, the branches numerous, thin, flattened, concrescent, dilated above and spathulate or fan-shaped, often somewhat longitudinally curved or wavy, mostly uniformly colored, rarely with a few indistinct, nearly concolorous, transverse zones near the broad entire apices.

Spores, subglobose, or broadly elliptical, .0002 to .00025 inch long, .00016 to .0002 broad.

This species is evidently closely allied to S. spathulata, Schw., but differs especially in its paler color, with no rufescent hues, in its much more branching habit, and in the absence of any distinct zones.

Prof. Peck writes as follows in a letter dated August 25, 1894: "That was a splendid fungus you sent me by express. I believe it to be an undescribed species of Sparassis. It comes near Sparassis spathulata, Schw., 
but that is described as 'pallide rufescens,' pale reddish, zonate and scarcely branched, 'vix ramosa' characters not applicable to your plant. I propose with your permission to name it Sparassis Herbstii, Pk."

Found it in an open oak woods under an oak tree near Cedar Fountain Creek.

\section{Genus LXVIII. CLAVARIA.}

Fleshy, branched, or simple, without any stem of a distinct substance. Hymenium dry.-Berkeley Outlines.

The Clavarei of the Lehigh Valley are quite common in a number of localities.

They are divided first into two sections: branched and the simple. The branched species are again divided into the white-spored species and ochraceous species.

\section{C. amethystina. Bull. Blue Clavaria.}

Fragile, much branched, violet blue, branches round, even, obtuse. Spores white.-Cook's British Fungi.

Common in Minesite woods.

\section{C. cristata.}

Branches white, dilated above in laciniate apices. Spores white.

Common on ground in woods.

C. pyxidata. Pers. The Cup Clavaria.

Fragile, waxy, much branched, with a thin main stem, white, branches ending in a cup, spores white.

Common on damp, rotten logs in the jungle.

\section{C. abietina. Pers. Firwood Clavaria.}

Very much branched, ochraceous, trunk somewhat thickened, clothed with white down, branches straight, crowded, longitudinally wrinkled when dry. Spores ochraceous. 


\section{C. inequalis.}

Yellow, gregarious, somewhat fasciculate, fragile, stuffed. Clubs variable, simple or forked, continuous downwards, of the same color. Spores white. - Stevenson's British Fungi.

Common in grassy lawns and cemeteries.

\section{C. spinulosa. Pers.}

Trunk short, rather thick ( 2.5 cent., 2 in.), pallid. Branches elongated, crowded, tense and straight, attenuated, somewhat cinnamon (fuliginous-date-brown: Pers.), of the same color at the apex.-Sterenson's British Fungi.

Common in woods on oak leaves. Kuhn's woods.

C. fragilis. Brittle Clavaria.

Fasciculate, fragile, clubs hollow, attenuated below, white. Albright's pasture land.

\section{C. mucida.}

Club simple, light yellow, becoming rufescent when old.

Found on a moist maple log covered with green algæ. Kuhn's woods.

\section{GenUS LXIX. CALOCERA. Fr.}

Gelatinous; tough when moist, horny when dry; hymenium viscid.-Cook's British Fungi.

\section{C. stricta.}

Simple, elongated; base blunt, linear, yellow, even when dry. Common on logs with a crack, from which the plant issues. Koch's Island. 


\section{GROUP II. BASIDIO-GASTROMYCETES.}

The name Gastromycetes or Gasteromycetes is derived from the Greek gaster, a stomach, and mukes, a fungus. The hymenium is enclosed in a cavity surrounded by a membranaceous covering called a peridium (from peridio, I wrap around), which sooner or later shed the enclosed spores, which are formed inside on basidii and spicules. The peridium may be simple or double. To shed the spores it may open by an orifice or it may open by decay. The cavity consists of two parts : the threaded part, which consists of threads called the capillitium, and a cellular part, from which the capillitium arises, is called the gleba. In some species the hymenium is deliquescent, such as the Phalloides.

Berkeley in his "Outlines" gives the following definition of this family: "Hymenium more or less permanently concealed, consisting in most cases of closely packed cells, of which the fertile ones bear naked spores on distinct spicules, exposed only by the rupture or decay of the investing coat or peridium."

The following natural orders are included under this group or family :

HyPOGEA.-Subterraneous. No specimen found.

Phalloides. - Terrestrial. Hymenium deliquescent.

NidUlARIACE

LYCOPERDACEA.-Cellular at first. Hymenium drying up into a mass of spores and threads.

Order I. PHALLOIDEAE. Fr.

Volva universal, the intermediate structure gelatinous. Hymenium deliquescent.-Berkeley Outlines. 


$$
1
$$



The following genera are included under this head:

Phallus. - Pileus free around the stipe.

Mutinus.-Pileus adnate to the stipe.

Phalilogaster.-Enclosed in a peridium, gleba lobed.

C.yanophallus. - No species found in the Valley.

Clathrus.-No species found in the Valley.

\section{Genus I. PHALLUS. Linn.}

Pileus perforated at the apex, free all around, reticulated.

\section{P. impudicus. Linn.}

Pileus, conical, reticulated; margin of the articulation nearly entire.

Stem, white, naked.-Berkeley Outlines.

This species is not as common as the duplicatus. The volva first issues out of the ground the size of a hen's egg, white, and consists of two coats distended with jelly. Odor carrion-like.

\section{P. duplicatus. Laced Stinkhorn.}

Volva, globose or oval, thick, whitish, sometimes with a pinkish tinge.

Stem, cylindrical, cellulose, tapering slightly upwards.

Vei1, netted, surrounding the whole of the stipe from pileus to volva, often torn.

Head or pileus pitted after deliquescence, apex acute, six to eight inches high.

Odor very repugnant, like unto rotten Limburger cheese. As disgusting as it is to the sense of smell, so beautiful it is to the sight. When perfect there can't be seen finer lacework than on this plant. It grows in lawns and open woods and is easily detected by its odor.

\section{P. Ravenelii. B. \& C.}

Pileus, or head, conical, elongated, surface not reticulated after deliquescens, the apex smooth and finally perforate. 
Stem, cylindrical, tapering at each end.

Veil, small, concealed by the margin of pileus.

Volva, globose or ovoid, pinkish, divided into segments. Size five to seven inches high; not near so robust as the other two species.

This is quite common in a locality called the jungle, near Trexlertown, during August and September.

\section{Genus II. MUTINUS. Fr.}

Pileus continuous with the stipe, the gleba covering the outside of the apex.

M. bovinus. Huds.

Pileus, acuminate, perforate at the apex.

Stem, cylindrical, tapering gradually to the apex, of a pinkish hue throughout, four to five inches high or higher.

Volva, oblong-ovoid, pallid, divided into two to three segments. Agrees well with M. caninus except the odor.

Found scattered specimens in different localities through the Valley.

M. brevis. B. \& C.

Pileus, broadly clavate, conical, but always more or less obtuse.

Stem, bright red, coarsely or pitted cribose, attenuated below.

Volva, globose, segments two to three, parted.

This is scarce in our Valley, and being so small it is easily overlooked. Found specimen in Laros's lawn, Breinigsville, $\mathrm{Pa}$.

\section{GENUS III. PHALIOGASTER. Morgan.}

Peridium pyriform, stipitate, consisting of a single layer, covered by an evanescent cortex. Gleba lobed, irregularly 
lobed. The entire contents deliquescent at maturity, adhering in distinct masses to the inner surface of the ruptured peridium.

\section{P. saccatus. Morgan.}

Peridium, spherical or pyriform, stipitate or nearly sessile, surface smooth, whitish, stained with a dull flesh color. Character same as in the genus.

Found under a spruce tree in Chas. K. Mosser's lawn, Breinigsville, Pa. Forwarded specimen to A. P. Morgan. 


\section{ORDER II. LYYCOPERDACEA}

Peridium composed of two distinct layers, globose, sessile, sometimes more or less stipitate. Hymenium filling the inside cavity, called the gleba; at length, when the spores begin to ripen, there is a copious effusion of water, of the color of the future spores; finally after maturity it is nothing but threads and spores, which are immense.

The following genera are included, viz:

QuELETIA.-Stipitate puffball.

GEASTER.-Earth stars.

BovisTA.-The Bovista puffball.

Clavatia. - The closed puffball.

LYCOPERDON.-The open (with a pore) puffball.

MitREMYCES. - The mitre puffball.

SCLERODERMA. - The hard puffball.

\section{Genus IV. QUELETIA.}

\section{Q. mirabilis. Fr.}

Peridium, globular, dirty white, smooth, dehiscent by decay. Inner peridium very thin, subgleba none.

Spores, light rusty.

Stem, free from the peridium, in a socket like the stem of Agaricus campester; elongated, lacerated, scaly, white, solid.

On a bed of spent oak tan, Mosser's tannery, I893. This is a very rare puffball. From a postal, in return from Prof. Peck after receiving a specimen for identification, I quote as follows:

"State Hali, Albany, N. Y., August, 26, I893. "My DEAR SIR: Thanks for your kind offer to send me more specimens of Queletia mirabilis. I would be glad to have a few more. So far you are the only one in this country to find it.

"Very truly yours,

"Chas. H. PhCK." 

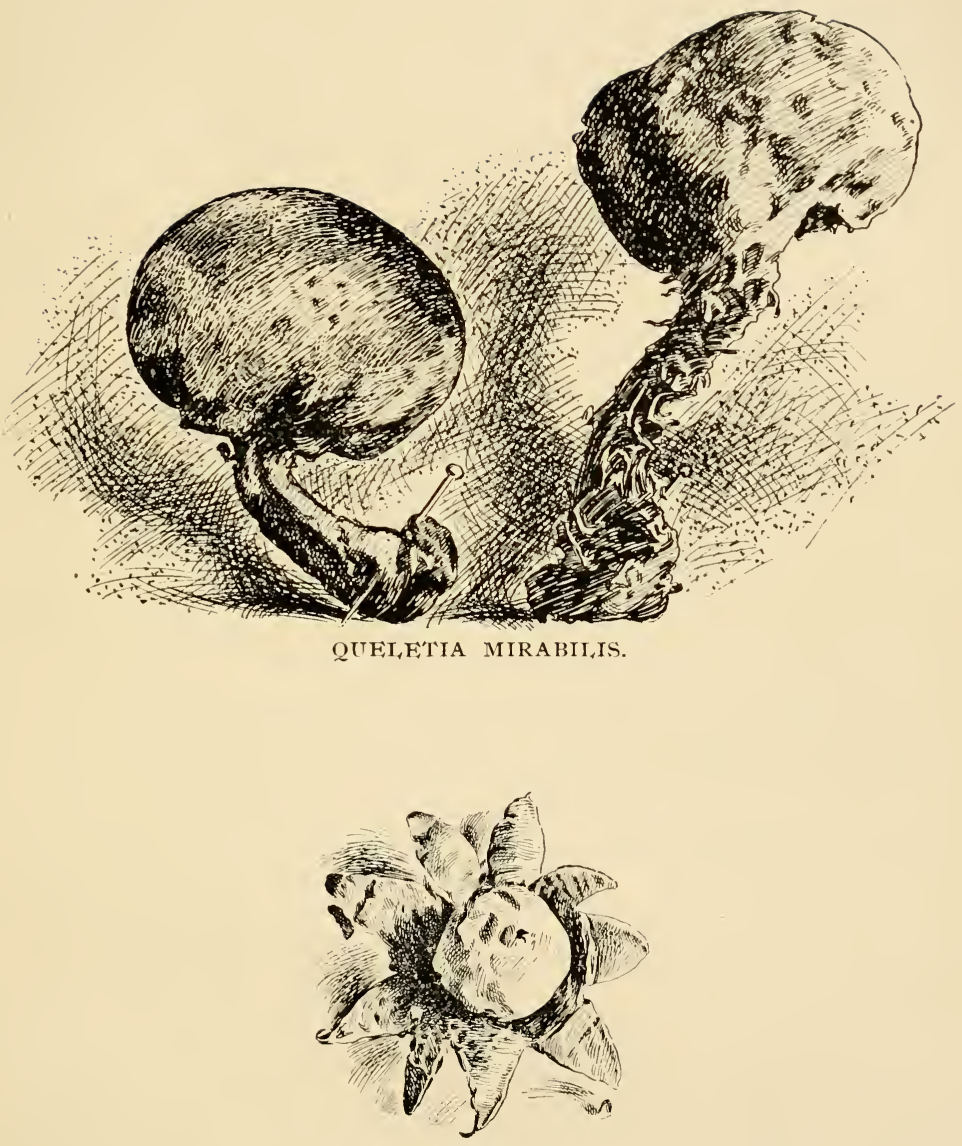

GEASTER MAMMOSLS. 

Genus V. GEASTER. Mich. Earth Stars.

Peridium globose, consists of two coats; outer coats splitting at the apex downward, into several segments, which become reflexed in a stellate form; inner peridium thin, membranaceous then papyraceous, sessile or with a short pedicel.

Capillitium takes its origin from the inner surface of the peridium, also a distinct columella. Threads simple, slender; spores small, globose.

\section{G. mammosus. Chev.}

Outer peridium, five to seven parted, sometimes more, hygrometric, sessile, pale to brown, mouth fimbriated, seated on a circle. Columella short, with a broad base.

Capillitium, thinner than the spores.

Found in different localities. Charles K. Mosser's lawn, under an evergreen hedge-fence.

\section{G. limbatus. Fr.}

Outer peridium, many parted, into seven to ten segments, stellate. Inner peridium globose, pale dark brown pedicellate, mouth lacerated.

Columella, large, convex, threads of capillitium thicker than the spores.

Spores, minutely warted.

Found in Spring Creek woods.

\section{G. minimus. Schw.}

Outer peridium multifid, the segments seven to nine parted. Inner peridium ovoid, pedicellate, white to pale brown, mouth conic, ciliate-fimbriate, seated in a plane circular disk. Columella slender, nearly obsolete; threads of the capillitium thinner than the spores, hyaline.

Spores, globose, warted.

Trexlertown cemetery. 
Genus VI. MITREMYCES. Nees.

Mycelium composed of numerous cord-like glutinous fibres, which branch and anastomose, forming a rooting base.

Peridium subglobose, composed of different layers, the outer one torn into segments. Mouth a stellate fissure of half a dozen rays. Capillitium threads long, slender, hyaline.

There is only one species of this genus.

\section{1utescens. Schw.}

Characters same as the genus.

Found specimens in Minesite woods, near Allentown, $\mathrm{Pa}$.

\section{Genus VII. BOVISTA. Dill.}

Peridium membranaceous, persistent, bark distinct, at length shelling off. Capillitium adnate to the inside of the peridium. Spores pediculate or sessile.

\section{B. pila. B. \& C.}

Peridium, globose, sessile, with a stout mycelium; cortex thin, white at first then brown.

Capillitium, firm, compact and persistent, at first clay colored, at length purple brown.

Found specimens in Spring Creek woods. Identified by A. P. Morgan, Ohio.

Genus ViII. Cravatia. Fr.

Peridium large, sessile; cortex thin, adherent. Inner peridium thin and fragile, breaking up into fragments from above downward. Spores and capillitium in a dense mass. 


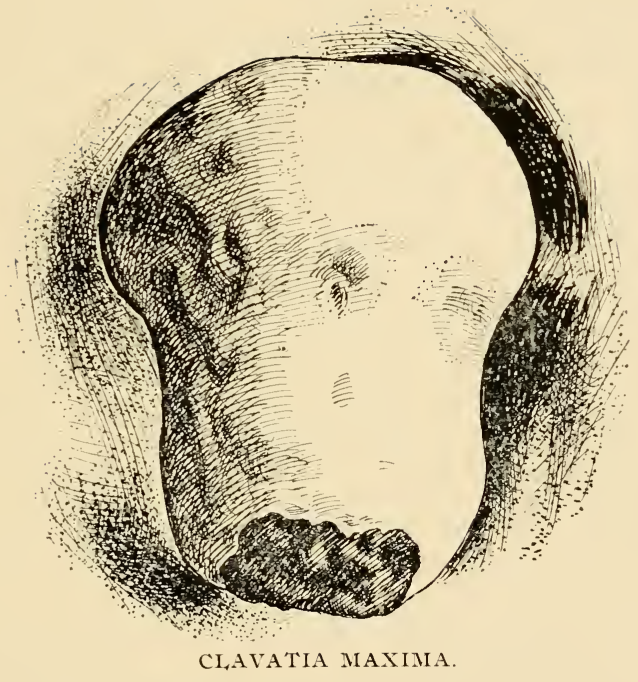





\section{C. maxima. Schaff. Giant Puffball.}

Peridium, large, five to ten inches in diameter, globose, white, cortex flocculose, or smooth and glossy. Inner peridium thin, breaking into fragments, subgleba shallow, or hardly any.

Spores and capillitium, greenish yellow, threads very long.

This is the Lycoperdon gigantea of most authors; it being separated by Fries on account of its dehiscing without a mouth. Edible. Common all through the Valley.

Nearly everybody, even the schoolboy, knows what a puffball or devil's snuffbox is. They shun it as a dangerous thing to handle, for fear the dust might come in their eyes and make them blind. The dust is really irritating, and is supposed to have narcotic properties, since the fumes are used to stupefy bees, to get the honey. As irritating as this dust is, so innocent the flesh is when eaten before it turns or is turning to dust. It is then excellent eating. Unfortunately this fungus deteriorates very speedily after gathering. If when cut or broken, yellow stains are seen, it ought not to be used. Mrs. Hussey says each slice ought to be dipped in the yolk of an egg and fried like an omelet.

The advantage of using puffballs as a diet is in its large size. One Lycoperdon giganteus is enough for a breakfast of two or three men. Also, it cannot be mistaken for a poisonous fungus, for all puffballs are safe, except the hard Sclerodermæ, which are too hard and bitter to be even tasted.

\section{C. cyathiformis. Bosc.}

Peridium, large, obovate, base thick, with a cord-like root ; cortex smooth, easily peeling off, gray, taking on violet.

Inner peridium, thin, pale purple, breaking up into scaly fragments.

Subgleba, large, taking up one-third of the cavity, concave or cup-shaped, purple.

Spores and capillitium, at first violet, then pale purple. Spores globose, echinulate.

In external appearance it is very similar to the C. maxima; but the purple spores and subgleba at once gives you the diagnosis.

Edible. Not as common as the C. maxima, and not quite as large. Along the roadside and grassy lawns. 
GENus IX. IYYCOPERDON. Fr. Puffballs.

Mycelium fibrous, rooting at the base. Peridium small, globose, obovate, with a thickened base; cortex with more or less spines, scales, warts, or granules. Inner peridium thin, dehiscent by an apical mouth. Subgleba cellulose, continuous with the capillitium. Capillitium and spores very abundant. Threads of two kinds: one set arises from the peridial wall and the other set from the subgleba.

This genus includes puffballs with an apical opening, whereas the Clavatia has none.

They are divided into two series, a purple-spored series and an olive-spored series.

\section{Purple-spored Series.}

\section{I. echinatum. Pers.}

Peridium, ovoid, with a narrow base, mycelium of slender white fibres; cortex covered with long brown spines, often coherent at the apex.

Subgleba, taking up one-third of the cavity.

Spores and capillitium, olivaceous, then violet, to brownish purple.

Growing on decayed leaves in open woods. Spring Creek woods.

\section{I. pulcherrinum. B. \& C.}

Peridium, obovoid, with a short base, mycelium a cord-like root; cortex covered with white spines, coherent at the base.

Subgleba, medium large.

Spores and capillitium, at first olivaceous, then brownish purple, spores globose, minutely warted.

Scarce in well-manured fields and woods. Found specimens in different localities.

\section{I. atropurpureum. Vitt.}

Peridium, dingy rufous, opening by a minute obtuse mouth, bark at first rough, with spines, sterile base, broad and shallow. 
Spores and capillitium, olivaceous, then purple, threads branched, the main stem about as thick as the spores. Spores echinulate.

Growing on the ground.

\section{L. glabellum. $\mathrm{Pk}$.}

Peridium, obovate, with a soft, delicate, velvety bark, yellowish, inner peridium smooth and glossy.

Spores and capillitium, olivaceous, then purple. Spores globular, warted.

Found specimens in chaparral ridgewoods.

\section{Olive-spored Series.}

\section{L. gemmatum. Fr.}

Peridium, turbinate, depressed above, elongated into a kind of thickened stem; bark farinose, adnate, covered with persistent warts or spines.

Spores and capillitium, olivaceous.

There is no species of puffball so common as this. You will meet with it not only in meadows and grainfields, but in open woods.

\section{I. separans. $\mathrm{Pk}$.}

Peridium, broadly ovate, often much depressed, plicate underneath, with a cord-like root; cortex a dense wlite coat of convergent spines, which at maturity peel off in flakes, revealing a thin furfuraceous layer of minute yellowish scales covering the inner peridium.

Subgleba, broad, occupying about one-third of the cavity. Spores and capillitium, dark brown.

Found specimen in an open grassy place in chaparral ridgewoods.

\section{I. pedicellatum. $\mathrm{Pk}$.}

Peridium, obovate, with a slender mycelium; cortex whitish, changing to dirty brown, covered with convergent 
spines at the apex; these at length fall away, leaving a wrinkled or obscurely pitted surface.

Subgleba, occupying about one-fourth of the cavity.

Spores and capillitium, olivacens brown, the thread much branched. Spores globose, with long persistent pedicels.

Scarce in the Valley. Found specimens in Albright's jungle.

\section{L. pyriforme. Schaff.}

Peridium, obovate or pear-shaped, with a profusion of mycelium threads; cortex with a thin coat of minute brownish scales or granules, which are quite persistent.

Subgleba, small, compact.

Spores and capillitium, brownish olivaceous, threads thicker than the spores.

Growing in compact clusters; so much so as to compress the inside specimens out of shape. Equally common with the L. gemmatum all through the Valley. This is about the only puffball that grows on wood.

\section{Wrightii. B. \& C.}

Peridium, globose, sessile, white, minutely spinulose, often converging at the apex.

Subgleba, obsolete.

Spores and capillitium, greenish yellow, then brown olivaceous. Spores minutely warted.

Common in gravelly paths. This is our sniallest puffball.

\section{Genus X. SCLERODERMA. Pk.}

Peridium firm, with an innate bark, bursting irregularly, flocci adhering on all sides to the peridium, and forming distinct veins in the central mass. Spores large, granulated.Berkeley Outlines. 


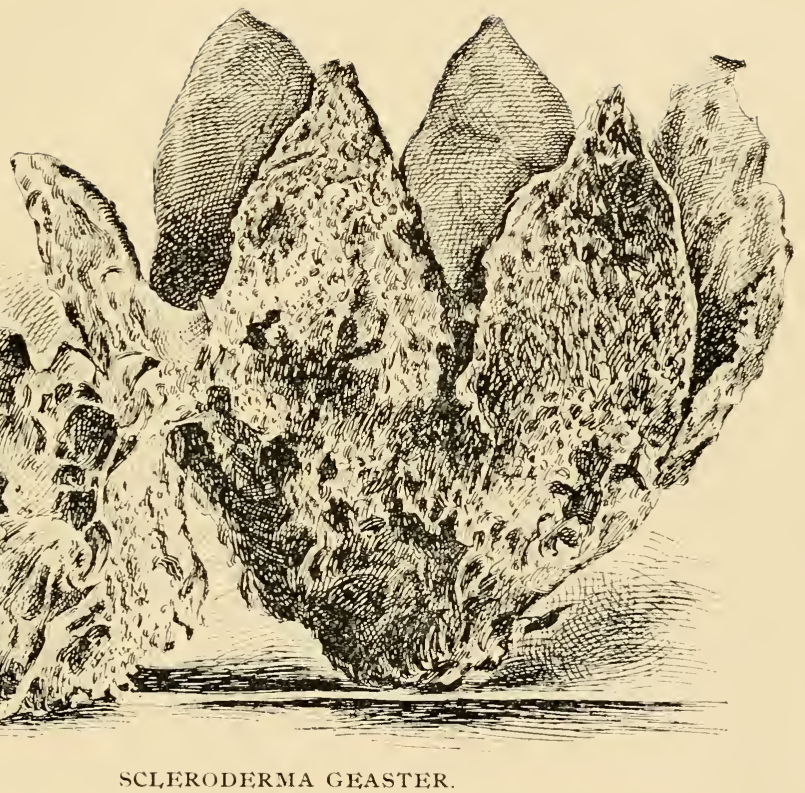



S. vulgare. Common Scleroderma.

Peridium, corky, hard, sessile, opening by fissures, inner mass bluish black.

Spores, dingy.

Common all through the Valley. Can pick bushels of it in some localities.

S. verrucosum. Pers. Warty Scleroderma.

Peridium, with a very short stem or almost sessile, warty, thin, and fragile; flocci and spores brown.

Common in open woods and roadsides.

\section{S. geaster. Fr.}

Mycelium a mass of fibres, larger than the plant itself.

Peridium, corky, hard, rough, dehiscing into irregular stellate limbs, buried part of the sessile base in the ground. Inner mass dark brown or black. The limbs, when extended, measure from four to five inches.

This interesting plant is scarce in the Valley. Found it growing at the side of the mountain road leading to a place called Stein's Spring, near Nacungie, $\mathrm{Pa}$.

There is a disagreement among the different authorities as to the priority of the different names of this plant. A. P. Morgan, of Preston, Ohio, the best authority in America, may be consulted on this subject. 
ORDER III. NIDULARIACEA. Tul.

Birdsnest Fungi.

Spores produced on sporophores, compacted into one or more globose or disciform bodies, contained within a distinct peridium.-Berkeley Outlines.

The genera included under this natural order are as follows:

Cyathus.-Peridium cup-shaped, of different membranes.

Crucibulum. - Peridium of one uniform membrane.

Nidularia. - Peridium globose, sporangia involved in mucous.

SPHERobolus. - Peridium double, sporangia ejected.

\section{Genus XI. CYATHUS. Pers.}

Peridium composed of three membranes, at length bursting at the apex, and closed by a white membrane. Sporangia attached to the walls by an elastic cord. - Berkeley Outlines.

\section{C. striatus. Hoffm. Birdsnest.}

Truncate, broadly open, externally ferruginous, hirsutotomentose, internally lead color, smooth, striated.

Sporangia, whitish, broadly umbilicate; covering of the cup thin ; spores thick, oblong.

This is a common fungus, growing on old stumps all through the Valley.

\section{Genus XII. CRUCIBULUM.}

Peridium consisting of a uniform, spongy, fibrillose felt, closed by a flat, furfuraceous cover. Sporangia plane, attached by a long cord, springing from a little nipple-like tubercle.Berkeley Outlines. 


\section{C. vulgare. Tul.}

Peridium, tawny tan color, externally nearly even, internally quite even, smooth, shining, mouth quite entire, naked. Sporangia pale ochre, whitish; spores minute.

Common on hemlock boardwalks and logs.

Genus XIII. NIDUIARIA. Tul. Imbedded Birdsnest.

Peridium globose, sporangia numerous, small, enveloped in mucous.

\section{N. pisiformis. Tul.}

Cæspitose in a nest, globose, rootless, brown.

Sporangia, subrotund, dark brown, spores colorless, elliptical.

On old logs throughout the Valley all summer.

GENUS XIV. SPHAEOBOLUS. Tode.

Peridium double, an inner one which is elastic, and when ripe ejects the sporangia for some distance.

\section{S. stellatus. Tode.}

Globose, pale yellow, outer peridium of two coats lined by an inner elastic one. The outer peridia split in a stellate manner, and the inner suddenly inverts itself and throws the sporangia to a considerable distance.

Not common in the Valley. Found specimens in Spring Creek woods. 


\section{GROUP III. BASIDIO-UREDINEAE.}

The old name Coniomycetes of Fries denotes more fully the nature of this group than the one in use at the present time. Coniomycetes means dust fungi, for the species are distinguished for the vast predominance of dust-like spores. They are divided into two series: those growing on dead or dying plants (saprophytic), and those growing on living plants (parasitic). The species of former series are no doubt dualisms of higher fungi ; the structure of the greater part of them is very similar. All are interesting in so far as dualism is concerned, and the beautiful varieties and fascinating forms of the spores, by which they are determined, is interesting. There is nothing more true in the old adage, "The tree is known by its fruit," than in this group, for it is impossible to get any characters from the vegetative organs, which are nothing but small spots on old logs, dead leaves, etc.

There are three natural orders included under this series of the Uredines or Coniomycetes :

SPHERONEMEI.-Perithecium distinct, free.

Melanconier.-Perithecium wanting.

TORLULACEI.-Spores tomiparous.

The number of complete and autonomous species are very few, if any. For the descriptive literature in conjunction with the Pyrenomycetes, I would refer you to Ellis's great work on this subject.

\section{SERIES II. Parasitic Uredines.}

The species of this series only grow on living plants; the mycelium threads are imbedded in the tissues of the host-plant. The Germans call this series Hypodermei on account of their 
forming under the epidermis of leaves, petioles, and even flowers. They are of far greater importance than the first series, since they are very destructive to the different kinds of fruits and cereals. They are commonly called ruts and brands. Dualism is frequently met with in this series in the form of uredospores or rust, and teleutospores or brand; the former stage is also called the summer spores, and the latter the winter spores. This class of fungi are frequently called microscopical fungi, since their identity can not be accomplished unless you bring to your aid a good compound microscope of a medium power, with a one-fifth objective. To study this series of Uredines a person ought to be well acquainted with our phanerogamous plants, especially with the specific botanical name, for the parasite is generally named after the specific name of the plant.

The natural orders included under the parasitic Uredines are as follows :

ECIDIACE两.

PUCCINIACEA.

Cooke, in his British Fungi, has a large natural order under this group, Cæomacei, the genera of which are now included under the above two natural orders.

\section{ORDER I. ACIDIACEAE.}

Peridium distinctly cellular, cup-shaped, margin free.

The following genera are included, viz:

Roestelia.-Peridium elongated.

PERIDERMIUM.-Peridium elongated, growing only on pine needles.

Fcidium.-Peridium cup-shaped, margin recurved.

C死OMA.-Spores in vertical chains, with spermogonium. 
GENUS I. RESTEIIA. Reb.

Peridium elongated, at length opening by lateral fissure or terminal mouth. Spermogones on the opposite surface of the same on different leaves.

\section{R. 1acerata.}

On the under surface of the green leaves of the common hawthorn. Crætegus.

R, aurantiaca. $\mathrm{Pk}$.

Peridium, elongated, at length opening by a crown. Spores, orange yellow.

\section{Genus II. PERIDERMIUM. Chew.}

Peridermium elongated, at length bursting irregularly. Spermogonia scattered, conspicuous.

P. pini.

Peridium, oblong, scattered, large, spores orange color.

On pine needles. Trexlertown cemetery.

Genus III. AECIDIUM. Pers. Cluster Cups.

Peridium not elongated, cup-shaped, opening by a terminal mouth, bordered by a fringe of revolute teeth. Spores disposed in chains, spermogonia on the same or opposite side.

\section{A. Berberidis. Pers.}

\section{Barberry Bush Cluster Cup.}

Spermogone none. Spots roundish, bright red, peridia in round, oval patches. Spores orange.

Said to be a part of the Puccinia graminis cycle. On the common barberry bush. 
A). podophylli. Mandrake Cluster Cup.

Spots, round, scattered, bright yellow, hypophyllous.

Spores, abundant.

The spots change to teleutospore spots early in summer.

Common on the leaves of the mayapple. You can hardly find a leaf that has not some of those parasitic spots.

A. œnothera. The Evening Primrose Cluster Cup.

Spores, of a beautiful pink color, coloring the leaf more or less on both sides. Has the teleutospores following close on the ripening of the uredospores.

Common on the evening primrose.

A. caltha. Grev. Cowslip Cluster Cups.

Growing on the caltha palustris leaves in clusters; somewhat campanulate.

Spores, bright orange, subglobose.

AE. grossulariæ. D. C. Currant-bush Cluster Cup.

Peridia, in dense clusters; spots yellow on the under side of the leaf and petiole.

Spores, orange.

Common on the wild currant bushes all through the Valley.

王. Sanibuci. Elder-bush Cluster Cup.

Peridia, in dense clusters, covering nearly the whole of the under surface of the leaf; of a beautiful yellow color. Cups are beautifully visible with a common lens.

The petioles of the common sambucus Canadensis are often neariy covered with this parasite.

死. violæ. Schw. Violet Cluster Cup.

Peridium, small, yellow, becoming brown on the under side of the leaf.

On viola rotundifolium. 
ÆE. compositarum. Mart. Solidago Cluster Cup.

Spores, purplish, round, confluent. Peridia crowded, in round patches. Spores round, patches.

On Solidago lanceolata.

\section{E. geranii. D. C. Cranesbill Cluster Cup.}

Peridia, in circular patches, with a bright red border.

Spores, yellow, on the under surface of leaves.

A beautiful object with a common lens. Common on our geranium maculatum.

E. ranunculi. Schw. Crowsfoot Cluster Cup.

Peridia, small, scattered, yellow.

Spores, also yellow.

Common on ranunculus abortivus, which is quite numerous in our open woods.

$\nexists$ E. convallariæ. Schw. Solomon Seal Cluster Cup.

Peridia, in large patches, light yellow or nearly white.

Common on polygonatum.

\section{GENUS IV. CAEOMA.}

Spots becoming a powdery mass; spores bright orange; spermogonia present.

C. nitans. Schw. Common Blackberry Rust.

Spores produced in vertical chains, spermogonia present. Spots, bright orange, sometimes covering the whole leaf.

This parasite is so well known that it is barely necessary to give all the microscopical characters. If you see a blackberry bush dusted over with an orange dust during June and July it cannot be anything else but the nitans, Schw. The vegetative part or mycelium permeates the cellular portion of the leaf, sucking the life out of the plant. The spores are very irritating; so much so that $I$ have had cases similar to hay fever from inhalation. Common on our blackberry bushes. 


\section{ORDER II. PUCCINIACEA.}

Parasitic on living plants; peridium none; spores mostly of two kinds, simple and septate, the latter producing on germination, secondary spores.-Berkeley Outlines, p. 328.

The genera included under this order are :

UROMYCES.-Spores with a permanent pedicel.

Phragirdiuir. - Spores multiseptate.

Triphragindiuni. - Spores biseptate.

Puccinia.-Spores uniseptate.

GymnosporangIum.- Spores imbedded in a gelatinous mass.

Genus V. PHRAGMIDIUM. Link.

Spores cylindrical, multiseptate, scarcely moliliform, borne on long peduncles.

\section{P. mucronatum. Link.}

Uredospores, spots yellow, small, scattered, spores oval.

Teleutospores, scattered over the leaves in tufts; spores five to seven banded, terminal joint mucronate.

On our rose leaves.

\section{P. clavellosum.}

Teleutospores, with a dull yellow stain on the upper surface.

Spores, four to five parted, peduncle clavate.

Common on aralia nudicaulus.

\section{Genus VI. PUCCINIA. Pers.}

Uredospores subglobose, brand spores uniseptate, supported on a distinct peduncle.-Berkeley Outlines. 
Spores at maturity forming more or less of a powdery mass, with permanent basidio, usually dark brown, two-celled, septum transverse.

The species included under this genus are what are called in common, brand (teleutospores). They are supposed to carry the uredospores through the winter, which in early spring will germinate and again form uredospores.

For a fuller description and good illustrations of this genus, I would recommend Peck's Report, No. 25, p. 11 Io.

\section{P. graminis.}

Uredospores, spots yellow, scattered nver upper surface of the leaf, bursting lengthwise; spores globose, generally called rust.

Teleutospores, spots darker, sori linear spores black or brown under the microscope.

On leaves and culm of grass or grain.

\section{P. podophylli or aculeata. Schw.}

\section{Mayappie Brand.}

Acidium spore in the form of Acidium podoplyyllum. No true uredospores present. .

Teleutospores, following the disappearance of the cluster cups. Spots brown, with the upper side yellowish

Spores, peculiar, two-celled, with a broad band nearly in the center, rough, with spines, giving it the appearance of a bug.

Common on the leaves of Podophyllum peltatum. All through Lehigh County, Pa.

P. circeæ. Enchanters' Nightshade Puccinia.

Spots, white on the lower surface, making the upper surface pale.

No uredospores found as yet.

Teleutospores, light colored short peduncle.

Found on circeæ in woods. 
P. thalictri. Chevil.

No uredospore found.

Teleutospores, dark brown, rough with warts, a short peduncle.

On thalictrum cornuti or meadow rue.

\section{P. Hydrophylli. Pk.}

No uredospores.

Teleutospores, nearly the shape of the thalictri.

Sca ce. On Virginian water leaf.

\section{P. 1obeliæ. Ger.}

No uredospores.

Teleutospores, spots scattered on the under surface of the leaf, small and hardly discernable on account of the hairy surface of the leaf.

On Lobelia syphilitica.

\section{P. Maydis.}

This is the Puccinia sorghi. Schw. Indian Corn Brand.

Uredospores common before the brand spores appear. The rust spots generally appear about the middle of July.

Teleutospores appear later; best time to get specimens is after the corn straw is stacked late in fall or early in spring.

Not abundant enough to do any harm to our crops of corn.

\section{P. solidaginis. $\mathrm{Pk}$.}

No uredospores.

Teleutospores, spots dark, but very prominent on the Solidago nemoralis or goldenrod.

Quite common on the leaves of Solidago nemoralis during August. 


\section{P. Xanthii. Schw.}

No uredospores.

Teleutospores, in bright yellow spots, very conspicuous.

Spores, with long peduncles, cells unequal, hyaline.

Common on the leaves of Xanthium strumarium.

\section{P. coronati.}

Uredo and teleutospores very common on our oats (avena sativa), producing our oat rust, which is very injurious, destroying sometimes whole fields of oats.

\section{P. 1ychnidearum. Link.}

Uredospores, in summer yellow, round, scattered on the under surface of leaf.

Teleutospores, spots yellowish, becoming pale.

This is quite common on Sweet William, Lychnis chalcedonica. I found specimen in December.

GenUS VII. GYMNOSPORANGIUM. Link.

Peduncle extremely long, agglutinated by gelatine into a tremeloid mass. Spores uniseptate.-Berkeley Outlines.

\section{G. sabinæ.}

This is the cedar apple, hanging in gelatinous masses on our cedar trees during a wet spell in the month of May.

Uredospores, none, except from some other source.

Trees look beautiful when they are fresh. Common.

\section{GENUS VIII. UROMYCES.}

Spores unilocular, attached permanently to a decided peduncle of greater length.-Berkeley Outlines. 


\section{U. terebinthi. D. C.}

Uredospores and teleutospores on Rhus toxicodendron (ivy poison). The leaves are covered with the parasite. This parasite is no doubt a blessing to those who are subject to ivy poisoning, since this parasite sucks the life out of the weed and thus kills it.

U. Hedysari-paniculati. Schw.

Uredospores more abundant than the teleutospores. You find them together on one spot, or aggregate spots.

Common on Desmodium paniculata.

\section{U. caladii. Schw.}

Acidium, uredo, and finally teleutospores on one leaf.

Very common. After the middle of May it is very seldom that you can find an Ariscema triphyllum (Indian turnip) that is clear from either one of them. First comes the æcidium, then uredo, and one has barely disappeared before the other follows. Common on Indian turnip.

\section{U. trifolii. A. and S.}

Acidium, uredo and teleutospores on our common clover. The second crop of clover is the best to get specimens. The Uromyces Lespedezæ, Schw., is the same as the trifolii.

Common on Lespedeza capitata. 
GROUP IV. BASIDIO-USTILAGINEAE. Smuts.

Spores minute, sooty, developed either on delicate threads (hyphæ) or in compacted cells, arising first from a sort of semigelatinous grumous stroma. Parasitic ; attacking flowers, leaves, and stalks of herbaceous plants. The genera included, indigenous in our Valley, are as follows:

Phacelotheca. - Developed in the ovary of the Phenerogamic genus or Polygonum.

Entrioma.-Spots pale rusty brown, enclosed in a deformed tissue host.

Tilletia.-Spots pulverulent at maturity, black.

Ustilago.- Hymenium deeply seated in the tissue of the plant in the form of hyphæ, ultimately breaking in a powdery mass.

\section{Genus I. PHACELOTHECA.}

Spores developed in a receptacle formed by the fungus in the ovary ; columella present.

\section{P. polygoni.}

Produced in the ovary of the flowers of Polygonum amphibium.

Easily identified by walking through a bed of the host, for it is nothing but a mass of smut, the red spikes are nearly all changed to a sooty mass.

Koch's Island.

Genus II. ENTYLOMA.

Spots pustule-like, pale or rusty brown, parasitic on leaves and stems. 
E. menispermi. Farlow. Trelease.

On leaves of the yellow Parilla; the only species, and that is often overlooked.

\section{Genus III. TILIETIA. Fœtid Smut.}

Spores enclosed in the deformed tissue of the host.

T. fotens. B. and C.

This is the old Ustilago fœetens on our wheat heads. It is easily identified by the pulverulent condition of the head of wheat and the garlic-like odor.

\section{Genus IV. USTIIAGO.}

Spores smooth, verruculose, or muricate, maturing simultaneously.

\section{U. Maydis. Corda. Indian Corn Smut.}

Every farmer or schoolboy knows ton well what the corn smut is without a full microscopical description being giving of it. It would nevertheless be to their interest to study the life history, biological characters, the favorable or unfarorable circumstances for its development or its destruction, for there is no greater pest to the corn than this fungus. It not only' deteriorates the corn plant, destroying many bushels of the seeds, but also poisons the leaves and stalks for fodder, turning the sweet corn fodder into a bitter and disgusting feed. It is supposed to have a very deleterious effect upon pregnant cows, causing the premature dropping of the calf. An extract is used in medicine for hemorrhages, and in obstetrics in place of ergot of rye. 
There is an old superstition among farmers that the burning of seed corn cobs produces smut, and you can find quite a number who adhere to that foolish notion. If they would burn the spores that would be wiser.

\section{U. segetum. Pers.}

Transforming the seed of oats (avena sativa) into a dusty mass. This parasite, like the Maydis, is equally as destructive to the grain. Some seasons whole fields are affected, making the crop almost worthless. Oats with a good quantity of smut makes it very unpleasant for farmers to handle; the inhalation and absorption of the spores is sickening, producing often a high fever for a few days. 
GROUP V.-BASIDIO-TREMELIINEAE. Fr.

Whole plant gelatinous. This natural order deviates from the typical Basidiomycetes in so far that the basidio are imbedded in the form of sporophores, with the spicules elongated into threads. The following genera are included, viz:

TREMELLA.

Exidida.

HIRNEOLA.

Guepinia.

GenUS I. TREMELIA. Fr.

Gelatinous, tremelous. Hymenium surrounding the whole plant, not papillate.

T. 1utescens. Fr. Yellowish Tremella.

Gelatinous, convoluted, gyrose, pallid, then a light yellow.

Common on decaying branches of trees all through the Valley.

\section{T. mesenterica. Retz.}

Orange, expanded over the subiculum, convoluted, gyrose, various in extent.

Common on dry alder $\mathrm{n}$ willows along the Lehigh River.

\section{T. vesicaria. Bull.}

Firm, bladdery, waved and wrinkled, viscid within which becomes hard when dry. Sporophores globose.

On the ground in woorls near Fogelsville. 
T. violacea. Morgan.

Effused in form of a beautiful violet gelatinous mass.

Common on recently cut maple stumps.

Genus II. EXIDIA. Fr.

Gelatinous, margined, fertile above, barren below.

E. glaudulosa. Fr. Witches' Butter.

Blackish, flattened, undulated, soft at first and when moist, becoming film-like when dry.

On dead oak branches all through the Valley.

Genus III. HIRNEOLA. Fr.

Gelatinous, cup-shaped, horney when dry. Hymenium wrinkled, without papillæ, outer surface velvety.

\section{H. Auricula-Judæ. Jews' Ears.}

Gelatinous, concave, lobed, thin, tomentose beneath, brownish, when covered with the white spores cinereous.

Common on decayed logs. When growing from the side of a trunk the lobes have the appearance of a human ear.

\section{GLnus IV. GUEPINIA.}

Gelatinous, inclining to cartilaginous, free, different on the two sides, variable in form, substipitate. Hymenium confined to one side. 


\section{G. spatularia.}

Yellow, cartilaginous when dry, spatulate, expanded above, hymenium slightly ribbed, contracted where it issues out of the log.

Common through the Valley. 


\section{ASCOMYCETES.}

Spores enclosed in a sac, or ascus. To distinguish them from Basidiospores they are called sporidia.

The essential character of this important division consists in the development of definite or indefinite sporidia, within certain external cells of the hymenium called asci, frequently accompanied by inarticulate or septate, simple or branched, threads, which are abortive asci, known under the name of paraphyses. -Berkeley Outlines, p. 270.

The following natural orders are included under this group :

ONYGeNeI.-Parasitic on insects, etc.

PERISPORIACEI.-Powdery mildews.

SPHARIACEI.

$\left.\begin{array}{l}\text { PPHARIACEI. } \\ \text { PHACIDIACEI. }\end{array}\right\}$ - Pyrenomycetes.

TUBERACEI.-Elaphomyces.

ELVHLLACEI.-Discomomycetes.

These natural orders are also divided into Discomomycetes. The former includes Elvellacei and the latter consists of Sphæriacei and Phacidiacei.

\section{ORDER I. EIVELLACEI.}

Hymenium at length more or less exposed; substance soft. -Berkeley Outlines.

This is also Discomomycetes, for the hymenium in many species is in the form of a disc.

The following genera are listed in our Valley:

MorCHELLA. - Pileate, deeply folded and pitted.

HeLVELLA. - Pileate, concave below. 
LEOTIA.-Pileate, margin revolute.

Geoglossum.-Clavate.

Peziza.-Cup-shaped, soon open.

Helotium.-Cup-shaped, disc always open.

BULGARIA.-Disc orbicular, glutinous within.

\section{Genus I. MORCHELLA. Dill.}

Receptacle pileate, hymenium in folds and pits.

\section{M. esculenta.}

Pileus, round, obtuse, adnate at the base, two to three inches high, one-half inch thick, yellowish.

Prof. Peck gives three or four species of Morchella, which he considers as edible.

This is one of the best of fungi to use for food and is easily identified. Our Pennsylvania farmers know them as merkel, and search for them for a good meal in the form of a potpie.

\section{GENUS II. HELVELIA.}

Receptacle pileate, hanging down over the stem; concave and barren below; hymenium even.-Berkeley Outlines.

\section{H. crispa.}

Pileus, deflexed, lobed, free, crisped, yellowish.

Stem, costato-lacunose.

Asci, clavate, sporidia ovate.

This is scarce in the Valley. Found specimens near Allentown in an open woods.

\section{H. elastica.}

Pileus, free, inflated, acutely lobed.

Stem, elongated.

Not very common. 


\section{GENUS III. LEOTIA.}

Receptacle pileate, margin revolute.

\section{1ubrica. Pers.}

Tremelloid, swollen, greenish yellow.

Stem, hollow, yellow.

Asci, cylindrical, sporidia oblong.

More common than the rest of the family.

Genus IV. GEOGLOSSUM. Earth Tongue.

Receptacle clavate, simple, hymenium surrounding the club.

$$
\text { G. nigritum. } \mathrm{Pk} \text {. }
$$

Club, dark black, two to three inches high.

Common in the vicinity of Trexlertown.

$$
\text { G. 1uteum. }
$$

Club, yellowish, much smaller than the nigritum. Found near Whitehall.

\section{GenUS V. PEZIZA.}

Cup-shaped; cup more or less concave, closed at first, but soon open, disc naked. Asci fixed, that is, imbedded.

The species included are generally small; a few are of considerable size. Every shade of color imaginable may be seen. None are edible.

\section{P. coccinea. Carmine Peziza.}

Stipitate, hemispherical, disc carmine, then orange. Asci with eight sporidia enclosed.

Scarce in the Valley. 
P. 1uteo-nitans. B. and $\mathrm{Br}$.

Cup, bright yellow, concave, irregular, flexuose; asci linear; sporidia elliptic, with two nuclea.

Common on grassy lawns.

P. floccosus. Schw. Wooly Peziza.

Cup, white, wooly externally, with a bright red disc, funnel-shaped.

Found a few specimens near Allentown, Pa.

\section{P. badia.}

Cup, waved, brown, margin involute, external pruinose.

Sporidia, obovate, epispore rough.

Found specimens in different localities in the Valley.

\section{P. occidentalis.}

Cup, infundibuliform, disc carmine, external pruinose.

Sporidia, oblong.

This is a beautiful Peziza growing in different places in the Valley. It appears early in June.

P. virginea. Virgin-white Peziza.

Stipitate, white, cup round, externally beset with crowded patent hair, small, not much larger than a pin's head.

Common on herbaceous twigs, especially on the dry stalks of Eupatorium fistulosa, growing in the Albright jungle, Trexlertown, Pa.

\section{Peziza. Undetermined.}

Sessile, concave, disc red, with margin beset with long black bristles, external wall with shorter hairs, one-eighth inch in diameter.

Common in moist places on rotten sticks. 


\section{P. (Dermatea) furfuracea.}

Sessile, between fleshy and coriaceous, externally pallid, mealy, margin rolled in; disc dark brown.

Common on alder branches. You need not look for them before October, when there is quite an abundance.

\section{Genus VI. HELOTIUM. Fr.}

Disc always open, dilated, convex or concave, naked.

\section{H. æruginosum. Fr. Green Helotium.}

Whole plant verdigris green, head small, turbinate, mycelium green.

This plant has different names; Fries at one time took it for a Peziza and called it Peziza æruginosa. Tulane called it Chlorosplenium æruginosum. The mycelium stains the wood to a beautiful green. The fully developed specimen is very rare. On oak. The mycelium stage is common in the Valley.

H. 1utescens. Fr. Yellowish Helotium.

Yellowish, small, sessile, or attached by a very short stipe. Common on half-decayed branches lying in a damp place.

H. citrinum. Fr. Lemon-colored Helotium.

Head small, crowded, concave.

Sporidia oblong, elliptic.

Common on willow twigs lying in a moist place.

\section{GenUS VII. BUIGARIA. Fr.}

Receptacle orbicular, glutinous within, at first closed; hymenium even, persistent, smooth.

\section{B. inquinans. Fr.}

Cup-shaped, firm, rugulose, light umber, disc dark. Asci long; sporidia large, brown.

Common on rotten branches all through the Valley. 


\section{ORDER II. TUBERACEAE.}

Subterranean, hymenium waved and sinuate.

There is only one genus represented, thus far, in the Valley -and that is, viz:

\section{Genus VIII. ELAPHOMYCES.}

Integuments thick, hard; asci globose or ovate; sporidia consisting of several concentric utricles.

\section{F. granulatus. Fr.}

Cortex yellow when fresh, at length brownish, minutely granulose or papillose.

Asci with eight sporidia.

Found a beautiful specimen some ten years ago in chaparral ridgewoods. Sent a specimen to Prof. C. H. Peck for identification. The specimens had Torrubia capitata growing on each tuber. 


\section{ORDER III. PHACIDIACEAE.}

Receptacle more or less coriaceous or carbonaceous; disc at length exposed by a fissure of the outer coat.

This natural order, together with the Sphæriaceæ, forms what is called the Pyrenomycetes.

The best American literature on the subject is by J. B. Ellis, of Newfield, N. J.: "Pyrenomycetes of North America." I have examined very few species of this natural order, but I know that they are common in our Valley.

\section{GeNUS IX. PHACIDIUM.}

Perithecium bursting irregularly in the center by valvular teeth.

\section{P. carbonaceum. Fr.}

Erumpent unequal, black, dehiscing into obtuse pits, disc dry and black.

Common in spring on willow twigs.

\section{P. dentatum. Fr.}

Spot four parted, pallid, then black, disc ochraceous; asci linear, oblong; sporidia thread-like.

Found in jungle on oak leaves.

Genus X. RHYTISMA. Fr.

Perithecia forming a confluent mass opening by flexuous fissures.-Berkeley Outlines.

\section{R. Ilicis-Canadensis. Schw.}

Innate, round, costa-rugose, shining, disc black.

Common on leaves of Prinos verticillata all through the Valley where the black alder grows. 
R. salicinum, Fr.

Almost the same characters as the R. Ilicis-Canadensis, only that it has a different host.

Common on willow leaves. Leaves look as though they were sprinkled with pitch.

\section{R. acerinum. Maple Rhytisma.}

Spermagonia present in form of orbicular pustular spots, with a discolored zone.

Ascophore spots irregular, confluent, rugose, bursting irregular, disc growing pale.

Scarce on our maple tree leaves. 


\section{ORDER IV. SPHAERIACEAE.}

Perithecia carbonaceous or membranaceous, sometimes confluent with the stroma, pierced at the apex, and mostly papillate; hymenium diffluent.-Berkeley Outlines.

This natural order consists mostly of the pyrenomycetes fungi. The genera are divided into four tribes, viz:

NECTRIEI.

XYLARIEI.

VALSEI.

SPHÆRIEI.

\section{GENUS XI. NECTRIA. Fr.}

Perithecia free, clustered or scattered, colored, fleshy or horny.

Asci, e1ght or many spored; sporidia of two kinds.

N. cinnabarina. Fr. Vermilion Nectria.

Conidia spores are produced on Tubercularia vulgare.

Ascophore cæspitose, perithecia globose, corrugated, vermilion, at length brownish, osteola papillæform; sporidia uniseptate.

On currant bushes, frequently together with Tubercularia vulgare.

Genus XII. HYPOMYCES. Tul.

Parasitic on fungi; mycelium byssoid; perithecia small. Asci eight-spored. Only one species is known to me. 


\section{H. lactifluorum. Schw.}

Parasitic on Russula delica, turning it into an orange red mass, without much deformity. It is often mistaken for a new species, which I did when I first discovered it.

Spring Creek woods. Quite common.

\section{Genus XIII. HYPOCREA.}

Perithecia variable, pallid or colored. Asci eight-spored; sporidia uniseriate, didymous, with two globules.

The Hypocrea are numerous in our Valley, but not having paid special attention to the different species I would refer you to Ellis and Everhart's synopsis of the North American Hypocreaceæ in Journal of Mycology, Vol. II, I886, and Vol. III, I 887 .

\section{H. Richardsonia.}

Found it growing on dead twigs of Populus tremuloides.

\section{GeNUS XIV. EPICHLOE. Fr.}

Parasitic on grass, dark colored, perithecia fleshy, immersed in a myceloid stroma, sporidia linear.

\section{E. Hypoxylon.}

Parasitic on the nodes of Eriophorum viginicum or cotton grass. Stroma surrounding the stem. Very destructive to the host plant.

Found in a swampy meadow near Trexlertown, Pa.

\section{Genus XV. TORRUBIA. Lev.}

Stroma vertical, fleshy, clavate, capitate; perithecia immersed; sporidia linear, multiseptate. 
T. capitata. Fr.

Fleshy, capitate, head ovate, bay brown, stem yellow, then blackish.

Parasitic on Elaphomyces granulatus.

Found several specimens, one of which was sent to Prof. Peck, Albany, N. Y.

Found in chaparral ridgewoods.

Genus XVI. CI,AVICEPS. Tul.

Stroma sclerotoid, subcylindrical; fructifying head distinct, fleshy, subglobose, colored ; asci linear, thickened at the apex ; sporidia filiform.

\section{C. purpurea. Tul. Eirgot.}

Stroma, horn-shaped, cylindrical, external pruinose, purple black, internal white or purplish.

Conidia spores are formed on the sclerotium.

Ascophore, fleshy, pale purple; head globose, tuberculose; stem short, flexuous; sporidia filiforn, colorless.

This wonderful fungus has a number of synonyms, no doubt owing to the different stages it passes throngh to reach perfection. Secale cornuti was one of the first names before the life history was known. It has been used in medicine from time immemorial, and is still used to some extent. The fungus is getting scarce. I remember some years ago when it was quite common on rye, even to the detriment of the farmers and millers.

It converts the rye grains into a useless mass for flour.

\section{C. microcephala. Tul.}

Stroma, horn-shaped, cylindrical, black externally, whitish internally. 
Ascophore, minute, head globose, stem long, slender, flexuous; asci with a tuber at the apex; sporidia colorless, filiform.

Growing on a species of grass along Spring Creek, Lehigh County, Pa. The sclerotium is not near so large as that growing on rye.

Genus XVII. XYLARIA. Fr.

Stroma corky, perithecia immersed, stipitate, sporidia uniseriate.

\section{X. polymorpha. Grev.}

Black, erect, hymenium bearing perithecia in every part.

Common in lawns under shrubbery throughout the Valley. Easily identified by the black color.

\section{X. digitata.}

Between fleshy and corky, cæspitose, heads cylindrical, reddish brown, then black, tips sterile; sporidia uniseriate, dark brown, curved.

On maple logs, jungle, Trexlertown, Pa.

A synopsis of the North American species Xylaria are fully given in Journal of Mycology, by Ellis and Everhard, Vol. III, ISS7; also in Peck's Reports.

\section{Genus XVIII. HYPOXYLON.}

Convex or plane, stroma corky or brittle. Perithecia immersed; sporidia ovate, or lanceolate, curved, dark colored, simple. This genus contains quite a number of good species, but, I am sorry to say, very few are fully identified. The most common in our Valley is the $\mathrm{H}$. multiforme and $\mathrm{H}$. rubiginosum. For further information see Journal of Mycology', by Ellis and Everhard, Vol. X, I889. 


\section{GENUS VALSA.}

Perithecia carbonaceous, perfect, circinating, elongated into converging necks; ostiola erumpent, jointed together or ending in a common disk.

\section{Americana.}

This is a common fungus on cordwood with the bark on.

\section{Genus X. SPHERIA. Hall.}

Perithecia black, carbonaceous pierced at the apex, mostly papillate, superficial or erumpent, without any stroma ; sporidia simple or septate, hyaline, or colored, variable.-Cooke's British Fungi.

\section{S. morbosa. Schw. Plum Knot.}

This fungus, according to the new nomenclature, is named Plowwrightea morbosa.

Perithecia, black, carbonaceous ; asci with eight sporidia, paraphysis accompanies the asci. Spermogonia are also present.

Conidia or summer spores are early and abundant. They appear as soon as the warn1 rains of June arrive, when you can find them on the different species of the plum and red sour cherry trees. The mycelium enlargement on the bark soon ruptures, when at the same time the hyphæ, bearing conidia spores, appear, giving the surface an olivegreen velvety appearance.

It is by means of these conidia spores that this fungus is so contagious. They ripen and are carried by insects and wind to new host trees, where under favorable conditions they form new fungal growths, and the fungus is spread indefinitely from tree to tree, from neighbor to neighbor.

The perithecia, with the asci, are found later after the conidia have done their work. They are the winter spores and do not ripen until February and March. It is wonderful how nicely these spore cases (perithecia) are imbedded in a hard crust for their winter quarters.

This fungus is peremilal, and having once gained a home in a twig will soon spread by new knots forming continually. 
This fungus is the greatest enemy to the fruit growers, since when a tree is attacked it means death to that tree and all surrounding trees.

There is no preventive except to watch and destroy the first appearance of the mycelium swelling, removing the branch and burning it immediately. It will not do merely to cut it and leave the branch on the ground, for the conidia and sporidia will ripen the same as if left on the tree. The watchword ought to be "remove and cremate."

GENUS XI. MELOGRAMMA. Tul.

Stroma subglobose, depressed, cellular; perithecia immersed, adnate; sporidia linear, lanceolate, or ovate, pleurilocular or simple.

M. gyrosum. Tul.

Spermogonia, very minute.

Ascophore, round, confluent, orange, stroma yellowish ; perithecia spiral, pulverulent.

Sporidia, linear.

Also called Eudothia gyrosa, Fr.

On bark of cornus florida.

\section{GeNUS XII. GIAENOSPORIUM.}

Perithecia imbedded in black bands, surrounding the twig. Sporidia oozing out of the stroma in the form of tendrils.

\section{G. Curtisii.}

Common on maple twigs, to the injury of young maple trees. 


\section{ORDER V. PERISPORIACEA}

Perithecia subglobose, always closed except by decay, mostly membranaceous, nucleus never diffluent. - Berkeley Outlines.

Many of the species are parasitic on living leaves. The genera included and found in our Valley are as follows :

UnCINUla.

Phylimactinia.

SPHEROTHECA.

MICROSPHÆRIA.

ERYSIPE and EROTIUM.

GENUS XIII. SPH EROTHECA. Lev.

Mycelium spiderweb, conceptacles globular, containing a single sporangium, appendages numerous, floccose.

S. pannosa. Rose Blight.

Mycelium, thick, woolly; conceptacles globose, white; sporangium many spored.

Common on our yellow rose bushes.

Genus XIV. PHYLLACTINIA. Lev.

Perithecia round, seated on a granular receptacle; appendages straight, ascicular, at length bent back.

\section{P. guttata.}

Amphigamous, mycelium web-like, conceptacles large, round, appendages hyaline.

On different species of deciduous undershrubs. This is the same species as the Phyllactinia suffulta, Reb. 
(YENUS XV. UNCINULA. L,ev.

Mycelium floccose, appendages rigid, simple, bifid or simple, uncinate, at length bent upwards.

\section{U. salicis. Winters.}

Perithecia, abundant on the upper surface of different species of willow and poplar.

Asci, oval, containing from four to six sporidia.

Jungle near Trexlertown, Pa.

\section{U. necator. Schw.}

Perithecia, medium size, dark colored so as to be easily distinguished.

Asci, ovate, acuminate, containing from four to six sporidia.

Appendages slender, the outer half hyaline, tips loosely coiled.

Common on our Virginia creeper. This is supposed to be, and no doubt is, the Uncinula spiralis, B. and C., or the powdery mildew on the grapevine.

The law of priority favors Ellis and Everhart's decision in their North American Pyrenomycetes, where they are taken as the Uncinula necator.

Genus XVI. ERYSIPHE. Hedw.

Mycelium spiderweb-like, appendages floccose, simple or irregularly branched. This genus is the type of this natural order, being also named Erysipheæ.

\section{E. graminis. Grass Blight.}

Perithecia, epiphyllous, large, mycelium effused, floccose ; appendages simple or interwoven with the mycelium.

On leaves of grapes. The conidia spores are the Oidium moniloides. 


\section{Genus XVII. EROTIUM. L. and C.}

Perithecia reticulated, vesicular colored, attached to mucidine threads; sporangia delicate.-Berkelcy Outlines.

\section{E. herbariorum.}

Characters same as the genus. This is proved to be an ascigerous part of the Aspergillus glaucus, a mucidine.

On dried plants, and other decaying substances. The meatus of the external ear is subject to a growth of this fungus, producing inflammation and dullness of hearing. 


\section{PHYCOMYCE'TES.}

Algæ fungi. The organs of fructification are so similar to some of the algæ tribes that it was considered a proper name for this group. They include some of the Mucidines of Fries. Many species are parasitic on cultivated plants, doing considerable damage to crops.

Spores like algæ spores are produced asexually as conidia and zoospores and sexually as zygospores or oospores.

The principal systematic literature is Berlese et De Toni Phycomycetex in Seccardo, Sylloge Fungorum.

The genera which I am able to describe, and indigenous in our Valley, are :

Cystopus.

PERONOSPORA.

PHYTOPHTHORA.

MUCOR.

\section{Genus I. CYSTOPUS. DeBary.}

Receptacle consisting of thick, branched threads; conidia concatinate, at length separating, oospores deeply seated on the mycelium.

C. candidus. Lev. Crucifera White Rust.

Conidia equal, globose. Oospores subglobose; epispore yellowish brown with regular obtuse warts.

In this genus there are two kinds of reproductive organs, those produced on the surface of the plant, bursting throngh the skin in white pustules, which DeBary called the conidia, and are generated in chains, 
and certain globose swellings termed oogonia, which are developed on the mycelium threads in the internal tissue of the foster plant. When these conidia are placed in water they rapidly absorb water and swell, and finally zoospores are generated, which soon begin to move, with their cilia, and by means of these cilia they disengage themiselves and become isolated. The movement is exactly that of the zoospores of algæ.

Common on Capsella Bursa-pastoris.

\section{Genus II. PERONOSPORA. DeBary.}

Mycelium threads mostly inarticulate, spores of two kinds, conidia on the tips of branchlets; oospores large, globese on the mycelium.-Berkeley Outlines.

P. gangliformis. Berk. Lettuce Blight.

Mycelium stout, torulose, threads branched, primary branches slender, acrospores minute, vescicular.

On garden lettuce.

\section{P. viticola. B. and C.}

This is what causes the dry rot of grapes, or downy mildew. Some years it is very damaging to our different kinds of grapes.

Genus III. PHYTOPHORA. DeBary.

The same characters as the Peronospora, with this difference, that the mycelium threads are septate.

\section{P. infestans. Potato Rot.}

Mycelium threads slender, destitute of suckers, fertile threads thin, gradually attenuated upwards, with one to five branches, with one or more spores at the tip.

This is the fungus which is responsible for the rotting of our potatoes. As early as I 846 this fungus was carefully described by the Rev. J. M. 
Berkeley, and later DeBary has given this fungus attention. The rapid decay of both foliage and tubers is a good character, accompanied by a very offensive odor, which is easily recognized by all who have once experienced it. The condition most favorable for the growth of this fungus is a moist and sultry atmosphere of a temperature of $70^{\circ}$ Fiahrenheit. The manner in which the germ tube of the conidia spores enter, the leaf is interesting.

The name "downy mildew" las been given to this fungus, since under favorable circumstances a downy or mould-like growth forms itself on the under surface of the leaf. Thus far the upper surface does not show any signs of the disease. This downy surface are the conidia spores with the hymenium threads. These conidia spores are light and may be carried long distances by the wind. It is largely owing to these spores that it is so infectious. After a time the top part of the leaf changes color, from a yellowish to dark brown or even black.

After these summer spores mature on the leaf, some fall on the ground and are brought in contact with the tuber, where they germinate and enter the substance of the potato, there to produce the same bad effect it had on the leaf and stalk. It is through the mycelium remaining in the potato that the fungus is carried through the winter.

As for a preventive, the best thing to do is to use some poisonous spraying mixture. Since Paris green is used so freely to destroy the potato bug, we have no trouble with this fungus. Paris green answers the double purpose of killing the potato bug and the Phytophora infestans.

Genus IV. MUCOR. Moulds.

Threads free, sporangia at length bursting. Zygospores present, developed on the mycelium.

\section{M. phycomyces. Berk.}

Mycelium obsolete, olivaceous, shining; sporidia yellowish.

To get specimens of this species, the best place is on old greasy cellar walls.

M. mucedo. L. Common Mould.

Byssoid, sporangia and sporidia globose, at length blackish. 
This is the kitchen mould, and gives that mouldy odor in damp weather. There is seldom to be found a preserved fruit jar that has not some nlould growing on the top.

M. caninus. P. Dog-dung Mould.

Fertile threads simple, sporangia yellow or ferruginous, globose.

On dung of cats and dogs.

M. fugiser. Agaric Mould.

Fertile threads simple, sporangia globose, hyaline, at length black, sporidia fusiform.

On decaying Agaric. 


\section{MYXOMYCETES.}

Slime moulds. Whole plant at first gelatinous. Mycelium often vein-like. Some authors do not consider those veins a mycelium, merely a part of the plasmodium, which, when mature, forms a mass of spores and threads, at length bursting. The ripe plant is so similar to the group Gastromycetes that M. C. Cooke, Rev. Berkeley, and other authors, had them placed under that group. This is a wonderful group; wonderful not for size and beauty but for their peculiar morphology, from a mass of slime in early morn to a beautiful network of threads and spores in the evening.

Mycologists could not agree as to whether to place it under the animal or vegetable kingdom. DeBary was of the opinion at one time that it belonged to a low order of infusoria, but he soon changed his mind and placed them in a fungal group (Myxomycetes). Unfortunately these beautiful objects of creation are unknown save to a privileged few who have, by the aid of a microscope, become acquainted with them. As said before, in their vegetative condition they consist of naked, motile, undifferentiated masses of protoplasm called plasmodium. This motile power of the plasmodium has deceived former naturalist to place them in the animal kingdom.

The fruit consists of an outside wall enclosing a mass of spores. If irregular in form it is called a plasmodiocarpa ; if regular, sporangia. A number of sporangia enclosed in an outside covering or peridium forms an æthalium. Sporangia may be sessile or furnished with a stipe, the stipe protruding into the chamber of the sporangium, forming a columella; threads forming a network is called, same as in the I,ycoper- 
dons, a capillitium. Lime, another animal character, which is present in the plasmodium, remains in the capillitium and peridium as calcareous nodes.

The species of this group are all interesting. They are nearly all small and easily overlooked. Most of the didymium are not much larger than a pin's head.

There are quite a number of good genera included under this group. My list represents only a few of the many, viz:

Craterium.-Opening with a lid.

PhySARUM. - Sporangium simple.

DiACHÆA. - Capillitium a network of violet threads.

Fuligo.- Ethalium not clustered, yellow and brown.

STEMONITIS.-Capillitium forming a network on the walls of the sporangium.

Dictydium. - With parallel ribs

Didymium.-Lime in crystal form on sporangium.

LyCOGALA. - Ethalium with a bark of colored cells.

LACHNobolus. - Capillitium grown to the walls of the sporangium.

ARCYRIA.-Capillitium free from the walls of the sporangium.

TRICHIA.-Threads of the capillitium simple.

HemiarCYRIA. - Threads of the capillitium more or less jointed into a net.

\section{GENUS I. CRATERIUM.}

Sporangium simple, rigid, closed on top with an operculum.

\section{C. leucocephalum. $\mathrm{Pk}$.}

Sporangium, more or less pyriform, stipitate, square sided, operculum thin.

Found in a lawn near Trexlertown, Pa., on a blade of grass. 


\section{Genus II. PHYSARUM.}

Capillitium present, sporangia covered with a crust of lime, rupturing irregularly Knots of capillitium filled with lime. Columella none.
P. alba. Fr.

Sporangium, delicate, depressed, white, flocci few, spores dark.

In gardens on tan walks.

\section{Genus III. DIACHAA. Fr.}

Peridium of the sporangia very delicate, falling off in fragments. Columella present.

\section{D. leucopoda.}

Sporangia, small, two lines high, one line thick.

Found by C. G. Lloyd, when on a visit to Trexlertown, in the jungle on an Asplenium felix fœmina-pinnæ. This is a beautiful myxo.

\section{Genus IV. FULIGO. Tanpit Slime.}

Athalia without columellæ, not clustered, yellowish, then brown.

F. vaporarium. Fr.

Yellow, effused over spent tan bark, in irregular patches; spores at length black.

Common on old oak stumps, apple pomace, etc., all through the Valley.

\section{Genus V. DICTYDIUM.}

Sporangia simple, delicate, capillitium wanting, wall of the sporangia with net-like thickening. 


\section{D. umbilicatum. Schrod.}

Sporangia, umbilicate, veins parallel, jointed by others which are transverse; spores purplish brown; about the size of a large pin's head, pendant, stipitate, stipe glossy.

Common on old stumps.

\section{Genus VI. DIDYMIUM.}

Sporangium with a membranaceous inner peridium, bursting irregularly; externally clothed with a crust-like outer peridium, which breaks into furfuraceous scales.

D. furfuraceum. Fr. Scurfy Didymium.

Sporangia, floccose, whitish, columella none, stem short, whitish, even; spores blackish.

Common on oak branches lying on the ground.

D. xanthopus. Fr. Yellow-stem Didymium.

Sporangium, globose, brown, whitish; stipe elongated, even, yellow; columella also stipitate into the sporangia.

On dead oak leaves.

D. cinereum. Fr. Ash-grey Didymium.

Sporangia, sessile, globose, whitish, covered with an ashy grey scurf; spores black. The size of a pin's head.

Common on fallen oak leaves.

Genus VII. IYYCOGALA. Mich.

Ethalium semiglobular, covered with a double membrane, persistent, bursting irregularly at the apex, externally warty or furfuraceous. Flocco adnate to the wall of the peridium. 


\section{I. epidendrum.}

Subglobose, pinkish, then brown; spores pale violet.

This is one of the most common Myxogaster to be found in the Lehigh Valley. It is easily identified by its appearing like so many small puffballs on decayed logs.

\section{Genus VIII. LACHNOBOLUS.}

Sporangia globular, simple, without a columella, capillitium present, grown to the walls of the sporangium.

There is only one species belonging to this genus, as follows:

\section{L. globatus.}

The characters are the same as the generic characters. They grow only on last year's chestnut burrs. The spines are literally covered with them, like so many homeopathic sugar globules.

July is the month to look for them under chestnut trees in woods.

\section{GENUS IX. STEMONITIS.}

Sporangia elongated, cylindrical, peridium delicate, evanescent. Capillitium reticulate, springing from a dark penetrating stem, or columella.

S. fusca. Roth. Dark-brown Stemonitis.

Sporangia, cylindrical, pointed at the apex, peridia fugacious, exposing the beautiful network of the capillitium. Spores dark brown.

This is quite common on decayed branches of trees lying on the ground all through the Valley. 
S. ferruginea. Rusty Stemonitis.

Sporangia, cylindrical, peridium fugacious, exposing the capillitium, of a rusty brown color.

Not as common as the S. fuscus.

\section{Genus X. TRICHIA.}

Sporangia without columella. Capillitium present, threads simple, spiral, turning to the right.

There are quite a number of species included under this most interesting genus, but there were only a few of which I was able to determine the proper specific name.

\section{T. clavata.}

Sporangia, obovate, yellow, shining, even, stipitate, stem yellow, peridium dehiscing irreyularly. Spores ochraceous. Capillitium consists of an intermingling of threads, so as to be impossible to trace a single thread to its end.

Common on rotten stumps.

\section{T. chrysosperma. D. C.}

Sporangia, rounded, subsessile, yellowish. Capillitium and spores ochraceous yellow. Threads of the capillitium of a definite length, smooth, occasionally echinulate.

Common on washerwoman's tub-bench or logs.

\section{T. rubiformis. $\mathrm{Pk}$.}

Sporangia, cylindrical, externally, reddish, with a bluish tint, fasciculate; peridia shining, obtuse, somewhat circumscissile; stem short, rubiginous, attenuated upwards.

This is called Hemiarcyria according to the new nomenclature, but I think it is still a good Trichia.

On rotten stumps, chaparral ridgewoods. 


\section{GenUS XV. ARCYRIA.}

Capillitium free from the walls of the peridium or only connected at the base; threads with spines, warts or rings. Sporangia simple without a columella. Flocci not spiral.

A. punicea. Pk. Splendid Arcyria.

Sporangia, stipitate, subovate, crowded, spores bright purple.

On rotten stumps in different localities throughout the Valley.

A. cinerea. Grey Arcyria.

Sporangia, ovate, cylindrical, cinereous. Capillitium, glaucous, as well as the spores.

More common than the above-mentioned species, size about two lines in height. 


\section{SACCHAROMYCETES.}

Yeast Fungi. The yeast plants are a low order of fungi, which reproduce by budding in place of spores, and are the active agents of fermentation. The raising of bread dough, the manufacture of beer, and even the acetic fermentation for vinegar, is all owing to this fungus.

The mucidine fungus, Penicillium crustaceum, is supposed to produce the myceloid condition called the mother of vinegar (Mycodermo aceti). For the species of this group consult Grove's synopsis of "Bacteria and Yeast-plant." 


\section{SCHIZOMYCETES.}

Bacteria. German, Spaltpilze. The fungi under this group are without a mycelium; consisting mainly of very minute organisms of different shapes and motile power. Their size is different, but mainly below two micromillimeter thick. They reproduce by segmentation or fission. From this mode of reproduction the Germans name them Spaltpilze, meaning to split or divide. Some species are beneficial in producing decomposition, in introducing nitrate into the soil, and thus fertilizing the farmers' fields; while others are exceedingly injurious in producing such diseases as tubercular consumption, smallpox, diphtheria, etc.

In any kind of fluid that has organic matter in it forms a culture fluid, and their multiplication is immense. A clear fluid will soon be turned to a cloudy liquid, with a dirty scum on top, called zooglœa. This is a wonderful group of minute organisms. The motile property of these organisms is indeed unique for vegetable life, and yet we have it in Myxomycetes, Phycomycetes, and quite common in Algæ.

It is an important fact that by appropriate cultures, modifying the organism, so that by inoculation with the milder germs, the disease is produced in a milder form, in passing repeatedly through animals they become exempt from that particular disease for some time to come.

\section{ORDER I. BACTERIACEFE.}

Mycelium wanting, reproduces principally by segmentation, can be cultured in a culture fluid. this natural order are numerous. I shall only mention a few. 
Micrococcus.-Segments globular, single or separate.

BACTERIUM. - Segments globular, adherent to each other.

BACILLUS.

LEPTOTHRIX. $\}$ Rod-shaped, with vacuoles.

BEGGIOTA.

Cladothrix.-Rod branched.

SPIRILLUM.- - Rod spiral, like a gimlet.

SPIROCH ETE. - Rod waved, with active movement.

VIBRIO.- - Rod waved, with a slow movement.

The best literature on this group is, viz: Marshall $\mathrm{H}$. Ward, on the characters or marks employed for classifying the Schizomycetes, Annals of Botany, Vol. VI, London, I892, pp. IO3144. He gives a brief outline of the history of the classification of bacteria, presenting in tabular form the various schemes proposed, as, viz: Cohn in 1875 . Winter in $\mathrm{I} 83 \mathrm{r}$, Van Teighem in 1884 , Flugge in 1886 ; in German, Hueppe in 1886 ; in German, Zoft in 1885 ; De Toni in 1889 , Woodhead in $189 \mathrm{I}$.

For those that can read German I would recommend Hueppe on Bacteria. For the biology, treating on this subject, DeBary is perhaps the best work. 


\section{LOCALITIES EXPLAINED.}

Localities mentioned in this list are no doubt strange to many of the readers of this epitome. The places mentioned are circumscribed areas on the west and north of the Lehigh river for a distance of ten to twelve miles.

Koch's Island is an open woods, with oak trees, surrounded by abandoned iron ore pits. This place is very rich in the growth of fungi. Situated about a mile northeast of Trexlertown.

Jungle. Situated near Trexlertown, consisting of about twenty acres of a variety of vegetation, from the common alder to large oaks and maple. A fruitful place for fungi.

Dorney's Woods, within three miles west of Allentown, consists principally of white oak timber. Very fruitful for the different species of Boleti. I gathered at one time five different species of Boleti in a few hours.

Griesemer's Hill extends from Griesemersville to Seventeenth street, Allentown. It consists of an undershrub grove of spruce, black haw, etc. Very few large trees. Found a number of fine species. Panus læve was found growing on an apple tree at the foot of the hill along the roadside.

Derolf Park, near Bethlehem, on the South Bethlehem electric road from Allentown, is a splendid location for specimens.

Fuller's Woods, near Catasauqua, where I found Amanita muscarius and the different species of Russulæ.

Chaparral ridgewoods, or "Krupsbuckel" of the Pennsylvania Dutch. This is a continuous stretch of woods, at least three miles long and two miles broad, situated about four miles west of Allentown, passing a little west of the famous Cedar Creek. Such a variety of the different species of timber as is here found, and surface elevations and depressions, forms a fruitful section for the growth of fungi.

Minesite Woods is situated southeast of Allentown, between three and four miles west of the Little Lehigh river. The territory is covered with chestnut, pine, maple, and oak timbers. These woods are noted 
for their variety of timbers. They consist of about Ioo acres in all. A good place for the different species of fungi. It was here that $I$ found the rare species of Mitremyces lutescens, Schw., and in abundance the Boletus granulatus.

Tpring Creek Woods. Situated where the Spring Creek enters the Little Lehigh, consisting entirely of white oak (Quercus alba) timber. The area is not large, only about twenty acres, but very fruitful in fleshy fungi, especially Russulæ and Lactarii.

Haas's Hill Woods, two miles west of Trexlertown, consisting of about two hundred acres of chestnut and oak timbers. It is here that I found the rare species Peziza floccosa.

Kuhn's Woods have a territory of at least fifty acres, consisting principally of white oak timber; has a number of winter ponds which become dry during the summer. Situated near Chapman's Station on the Catasauqua \& Fogelsville Railroad. These woods afforded quite a number of good specimens. It was here that I first found the species of Boletus inflexius, $\mathrm{Pk}$.

Fogelsville Woods. Situated one mile west of Chapman's Station, on the Catasauqua \& Fogelsville Railroad. The woods north of this place have a gravelly soil, and more hilly. The timber is more chestnut than in the bottom district. These are good fungi districts, but on account of the little humus in the soil, you find very few Boleti. The different species of Clavaria are very abundant in this slaty region. 


\section{GLOSSARY.}

A

ABERRANT, deviating from the type.

ABORTIVE, undeveloped.

ACEROSE, relating to pine leaves.

ACULEATE, covered with prickles.

ACUTE, sharp pointed.

ADHESION, union of different organs or tissues.

ADNATE, when two different organs are grown together.

ERUGINous, color of virdigris.

AGAMIC, without sex.

ALLIACEOUS, odor of garlic.

ALVEOLATE, honeycombed.

ANASTOMOSIS, connecting gills or veins.

ANNULAR, ringed.

ANNULUS, a ring.

ANTHEROZOID, male reproductive organs of fungi .

APPENDICULATE, furnished with an appendage.

ARACHNOID, spider-web like.

AREOLATE, pitted net-like.

ApICaL, near the top.

B

BASIDIOSPORES, the spores of higher fungi produced on stalks or basidio.

BIFURCATE, forked.

BULLATE, with a thickened top on the pileus.

CASPITOSE, in tufts.

C

CANRSCENT, with long pubescence.

CAMPANUlate, bell-shaped.

CAPIILARY, hair-like.

CAPILIITIUM, a network of threads in Lycoperdons.

CINEREOUS, ash-colored.

Cravate, club-shaped. 
Col,UNELLA, the axil of the sporangia of myxomycetes.

CONCENTRIC, having a common center.

CORIACEOUS, leathery.

Crustachous, crust-like.

\section{D}

DECURRENT, gills running down the stem.

DEHISCENCE, the opening of a pericarp.

DELIQUESCENT, dissolving into a fluid.

DENTATE, margin toothed.

Dichотомоus, two branched.

Dimidiate, gills reaching half way to the stem.

DISCIFORM, a flat surface.

$\mathbf{E}$

ECHINULATE, covered with prickles of small size.

EMARGiNATE, when gills are scooped out at the junction with the stem.

EPHEMERAL, lasting but a short time.

EPIDERMIS, the outer covering.

EXCENTRIC, attached outside of the center.

EXOSPORIUM, outer coat of spores.

FARINACEOUS, mealy.

F

FASCICULATE, clustered.

Fibrilitose, clothed with fibres.

FILIFORM, thread-like.

FIMBRIATH, fringed.

Fistulous, hollow.

FLOCCI, covered with woolly locks.

Fugacious, remaining only a short time.

FULIGINOUS, sooty brown.

Fulvous, tawny yellow.

FURCATE, forked.

Fuscous, grayish brown.

\section{G}

Grbbous, an excentric swelling on top of pileus.

GILLS, plates on Agarics.

GLAUCOUS, covered with a bloom.

GRUMOUS, consisting of granular bundles.

GYROSE, in wavy folds. 
$\mathbf{H}$

HABITAT, the range of growth.

HETEROGENEOUS, when structures differ when in juxtaposition.

HOMOGENEOUS, similar in structure.

HyGROPHANOUs, watery in appearance.

HYMENIUM, fruit-bearing surface.

HYMENOPHORE, the hymenium-bearing surface.

HYALINE, clear or transparent.

НуРнж, thread-like organs.

I

IMBRICATE, when scales overlap each other like the tiles on a roof.

IMMARGINATE, withont a distinct border.

INDIGENOUS, native to the country.

INFUNDIBULIFORM, funnel form.

INVOLUTE, rolled inwards.

ISABELLINE, yellow brownish color.

LACINIATE, divided into flaps.

\section{$\mathbf{L}$}

LACUNOSE, marked with hollows.

LANCEOLATE, tapering to a point.

M

MAMMIFORM, breast form.

MARGINATE, with a distinct border.

Merisnoid, a form of Polyporoid pilei.

MITRIFORM, mitre-like.

MYCErIUM, vegetative hyphre or spawn of fungi.

Mycology, the botany of fungi.

OBConic, upside down conic.

O

Oвоvaте, inversely egg-shaped

OBTUSE, blunt.

OCHRoleucous, yellowish white.

Oogonia, female reproductive organ of oophytes.

OPERCULUM, a lid.

OvaTE, egg-shaped. 
$\mathbf{P}$

PARAPHYSIS, filamentous organ accompanying the ascospores.

PAPILLATE, with one or more nipple-like elevations.

PeCTINATE, like the teeth of a comb.

PeNiCILLATE, shaped like a pencil of hair.

PERITHETHIUM, a flask-shaped organ producing ascospores.

PERONATE, sheathed like a legged boot at the base of stem.

PILEOLI, a divided pileus.

PILEUS, cap of Agarics.

PILOSE, covered with hair.

POROus, with pores.

PRUINOSE, with a frost-like bloom.

PUBescens, downy.

Pulvinate, cushion-shaped.

PIRIFORM, pear-shaped.

PyXIS, a pericarp with a lid or circumscissile.

$\mathbf{R}$

RADICAL, belonging to the root.

REMOTE, gills that leave a space free from the stem.

RENIFORM, kidney-shaped.

REPAND, bent backwards.

RESUPINATE, fungi with the hymenium on top.

REVOLUTE, rolled backwards.

RIMOSE, cracked or chinked.

RIVULOSE, marked with fine lines like river marks on a map.

RUBiginous, rusty color.

RUFESCENT, reddish.

RUFous, brownish red.

RUGose, wrinkled.

$\mathbf{S}$

SCABRous, rough on surface.

SCARIOUS, applied to a rugose membrane.

SCISSILE, when two plates easily separate.

SCLEROTOID, a hardened mycelium.

SCROBICULATE, with small pits.

SEPTUM, a partition.

SERICEOUS, with silky hair.

SERRATE, margin cut saw-like. 
SESSILE, without a stem.

SINUATE, same as emarginate of the gills.

SPATULATE, like a druggist's spatula.

SPERMOGONIUM, fruit cells accompanying the Uredines.

SPORANGIA, spore cases.

SQUAMOSE, scaly.

SQUAMUL,OSE, small scales.

SQUARROSE, rough with scales.

STIPITATE, with a stem.

STRIATE, generally used for the channeled margin of the pileus.

STRIGOSE, rough with hair.

SULCATE, marked with furrows.

TERETE, round.

THALLUS, applied to a plant body where there is no differentiation between the different tissues.

TOMENTOSE, downy.

TrAMA, substance parting the membranes between the gill plates.

TREMELLOID, jelly-like.

TRUNCATE, abruptly cut off.

\section{U}

UMBILICATE, with a central depression.

UMBONATE, with a central elevation.

UNCINATE, with a hook.

VAGINATE, sheathed.

\section{V}

VEIL, a covering of various texture; some like a spider web, others membranaceous, partially covering the fungus.

VENTRICOSE, swelling in the middle.

VERRUCOSE, warty.

VIL,LOUS, downy with soft hair.

Vorva, a universal veil.

\section{Z}

ZONED, with one or more concentric circles of color. 


\section{GENERA INDEX.}

Aicidium . . . . . . . . . . . . . . . . . I 73

Agaricus . . . . . . . . . . . . . . . . . 20

Amanita . . . . . . . . . . . . . . . 2 I

Arcyria . . . . . . . . . . . . . . . . $2 \mathrm{I} 5$

Armillaria . . . . . . . . . . . . . . . 36

Ascomycetes . . . . . . . . . . . . . . . . I88

Aspergillus .. . . . . . . . . . . . . . . . 204

Bacillus . . . . . . . . . . . . . . . . $2 \mathrm{I} 8$

Bacteriaceæ ................... . . $2 \mathrm{I} 7$

Bacterium .................. 2 . . . 28

Beggiota . . . . . . . . . . . . . . . . $2 \mathrm{I} 8$

Boletinus... . . . . . . . . . . . . . . II6

Boletus...... . . . . . . . . . . . I I 8

Bovista. . . . . . . . . . . . . . . . . . 164

Bulgaria . . . . . . . . . . . . . . . . . 192

Cæoma................. . . . I70

Calocera . . . . . . . . . . . . . . . . . I57

Cantharellus . . . . . . . . . . . . . . . 106

Cladothrix . . . . . . . . . . . . . . 218

Claudipus . . . . . . . . . . . . . . . . $7 \mathbf{I}$

Clavaria .................... . . . ${ }^{1} 56$

Clavatia ..................... I . I64

Claviceps... . . . . . . . . . . . . . . 198

Clitocybe .. . . . . . . . . . . . . . . . . 42

Clitopilus . . . . . . . . . . . . . . . . 57

Collybia . . . . . . . . . . . . . . . . . . 47

Coprinus. . . . . . . . . . . . . . . . . . 77

Corticium . . . . . . . . . . . . . . . . . 152

Cortinarius . . . . . . . . . . . . . . . . . 80

Craterellus . . . . . . . . . . . . . . . . 148

Craterium .................... . . 2 I0

Crucibulum . . . . . . . . . . . . . . . . 170

Cyathus . . . . . . . . . . . . . . . . 170

Cyphella..... . . . . . . . . . . . . . . 154

Cystopus. . . . . . . . . . . . . . . . . . 205

Dredalia . . . . . . . . . . . . . . . 140

Dermatea . . . . . . . . . . . . . . . . 192 
Diachæa

Dictydium

Didymium

Elaphomyces.

Elvellacei

Entoloma

Entyloma

Epicloe

Erotium

Erysiphe

Exidia .

Exobasidium .

Favolus

Fistulina

Flammula

Galera

Gasteromycetes

Geaster

Geoglossum

Glœosporium 2OI

Gomphidium

Grandinia

Gymnosporangium

Guepinia . I86

Hebeloma

Helotium

Helvella

Hirneola.

Hydnei

Hydnum .

Hygrophorus

Hymenochæte.

Hypholoma

Hypocrea

Hypomyces

Hypoxylon 
Lactarius . . . . . . . . . . . . . . . . IOI

Lentinus..................... . . . II3

Lenzites . . . . . . . . . . . . . . . . . II4

Leotia . . . . . . . . . . . . . . . . . 190

Lepiota . . . . . . . . . . . . . . . . . 32

Leptonia. . . . . . . . . . . . . . . . . 59

Leptothrix. . . . . . . . . . . . . . 2 I8

Lycogala . . . . . . . . . . . . . . . . . $2 \mathrm{I} 2$

Lycoperdon . . . . . . . . . . . . . . . . I66

Marasmius . . . . . . . . . . . . . . . . . . . . IO9

Melogramma .................. . . $20 \mathrm{I}$

Meruleus . . . . . . . . . . . . . . . . . . $\mathbf{I} 42$

Nicrococcus ................... 2 2 I8

Mitremyces . . . . . . . . . . . . . . . . . 164

Morchella . . . . . . . . . . . . . . . . . . . 189

Mucor . . . . . . . . . . . . . . . . . 207

Mutinus .................... I60

Mycena .. . . . . . . . . . . . . . . 48

Myriadoporus. . . . . . . . . . . . . . I I39

Myxomycetes . . . . . . . . . . . . . . . 209

Naucoria. . . . . . . . . . . . . . . . . 69

Nectria . . . . . . . . . . . . . . I96

Nidularia . . . . . . . . . . . . . . . I7I

Nolanea . . . . . . . . . . . . . . . . 59

Nyctalis . . . . . . . . . . . . . . . 108

Omphalia . . . . . . . . . . . . . . 50

Panæolus . . . . . . . . . . . . . . . . 76

Panus. . . . . . . . . . . . . . . . . IO3

Paxillus . . . . . . . . . . . . . . . . . . 92

Peridermium . . . . . . . . . . . . . . I74

Perisporiacei . . . . . . . . . . . . . . . 202 202

Peronospora . . . . . . . . . . . . . . . . 205

Peziza . . . . . . . . . . . . . . . . . 191

Phacelotheca . . . . . . . . . . . . . . I82

Phacidium . . . . . . . . . . . . . . . . . . 194

Phallogaster . . . . . . . . . . . . . I60

Phallus . . . . . . . . . . . . . . 159

Phlebia . . . . . . . . . . . . . . 147

Pholiota . . . . . . . . . . . . . . . 6 60

Phragmidium . . . . . . . . . . . . . . I77

Phyllactinia .............. . . . 202 
Physarum . . . . . . . . . . . . . . . 2 II

Phytophthora . . . . . . . . . . . . 206

Pleurotas . . . . . . . . . . . . . . . . $5 \mathrm{I}$

Pluteus . . . . . . . . . . . . . . . . . . . 55

Polyporus . . . . . . . . . . . . . . I30

Psathyrella ... . . . . . . . . . . . . . . 77

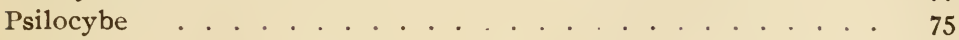

Puccinia . . . . . . . . . . . . . . 177

Queletia . . . . . . . . . . . . . . . I62

Radulum .. . . . . . . . . . . . . . . . . I 147

Rhytisma . . . . . . . . . . . . . . . . I94

Rœstelia . . . . . . . . . . . . . . . . . I74

Russula . . . . . . . . . . . . . . . . 93

Saccharomycetes . . . . . . . . . . . . 216

Schizomycetes . . . . . . . . . . . . . . . $2 \mathrm{I} 7$

Schizophyllum .................. 115

Scleroderma . . . . . . . . . . . . . . . . . ${ }^{168}$

Sparassis . . . . . . . . . . . . . . . . . ${ }^{1} 55$

Sphæria . . . . . . . . . . . . . . . . 200

Sphærobolus . . . . . . . . . . . . . . . . I7I

Spirillum . . . . . . . . . . . . . . . . 218

Spirochæte . . . . . . . . . . . . . . $2 \mathrm{I} 8$

Stemonitis . . . . . . . . . . . . . . 213

Stereum . . . . . . . . . . . . . . I50

Strobilomyces . . . . . . . . . . . . . . . . . I I7

Stropharia . . . . . . . . . . . . . . . 73

Tilletia ................ 183

Thelephora . . . . . . . . . . . . . . . . 149

Torrubia . . . . . . . . . . . . . . . . . . 197

Tramella ..................... . . ${ }_{185}$

Trametes.................. . . I40

Trichia ..... . . . . . . . . . . . $2 \mathrm{I} 4$

Tricholoma . . . . . . . . . . . . . . 36

Uncinula .. . . . . . . . . . . . . . . 203

Uromyces . . . . . . . . . . . . . . . $1 \mathrm{I}_{\mathrm{I}}$

Ustilago . . . . . . . . . . . . . . . . . . 183

Valsa . . . . . . . . . . . . . . . 200

Vibrio.................. . . 2 I $\mathrm{S}$

Volvaria . . . . . . . . . . . . . . . 54

Xylaria . . . . . . . . . . . . . . . . 199 






Herbst, William/Fungal flora of the Lehi

35185001157559 
